\title{
The Gaseous Metabolism and Blood Flow of the Brain.
}

\author{
I. Under Narcosis and Hypnosis.
}

(A Contribution to the Theory of Narcosis.)

\author{
By \\ MATAJURO YAMAKITA. \\ 山北义十郎) \\ (From the Laboratory of Prof. T. Kato's, Medical Clinic, Tohoku \\ Imperial (University, Sendai)
}

\section{Contents :}

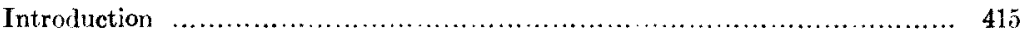

Method of experiment ...................................................... 417

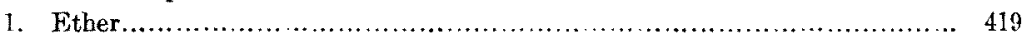

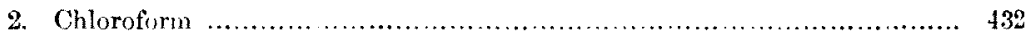

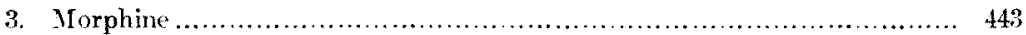

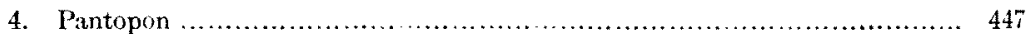

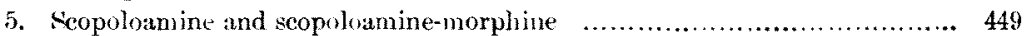

6. Magnesium and calcim................................................. 453

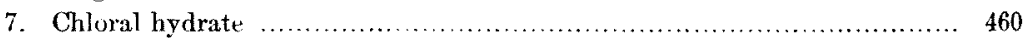

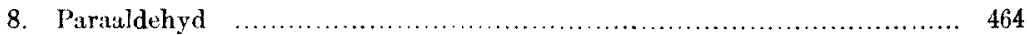

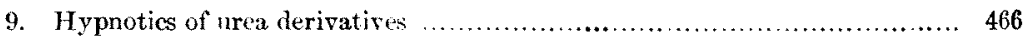

i. Urethine ............................................................. 466

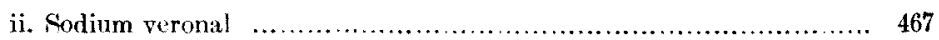

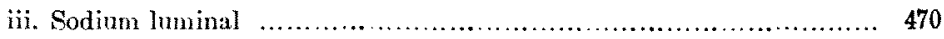

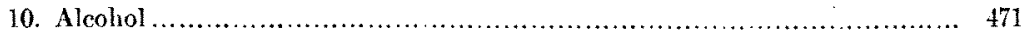

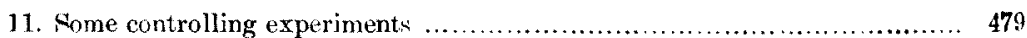

Summary and discussion .................................................... 481

Conclusions ............................................................... 491 
The stimulation to activity of all tissues and organs either by direct excitation or by drugs is generally accompanied by increased exchange of energy. In regard to the brain, there are only a few investigations on the energy exchange and these do uot agree with each other. Mossond Berger ${ }^{2}$ proved a rise of the temperature of the brain when excited, but later Rolleston ${ }^{3)}$ and $\mathrm{Hill}$ and $\mathrm{Nabarr}{ }^{4}$ ) opposed them; they stated that when compared with the muscles the brain is not a seat of active combustion. However, Alexander and Révész observed that the oxygen consumption in the brain of dogs is increased by $7 \%$ during the stimulation of the retina with light; Alexande $r^{6)}$ marking an increased volume velocity of the blood flow through the brain in such cases, showed that metabolic mechanism in the raised function of the brain combined with the increased exchange of energy was similar to that in all other organs. Winterstein demonstrated by experiment, also on the spinal cord, the increase in gaseous metabolism by $70 \%$ through its tetanic stimulation.

It is alleged that the central nervous system is extremetely sensitive to deprivation of oxygen and also that the narcotic disturbance of the brain function is the result of lack of oxygen; thus advancing the rocalled oxygen deprivation theory of narcosis. Verwor $\mathbf{n}^{8)}$ concluded from experiments on the spinal cord of frogs, that, narcosis was due to the depression of oxidation in the nerve cells, and also Mansfeld $d^{9 /}$ explained the narcosis by a decreased oxygen absorption of the lipoids.

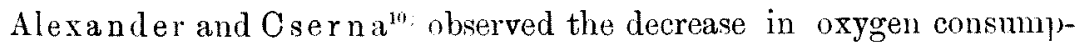
tion and carbon dioxide production during narcosis of the dog. Recently Hirschberg and Winterstein ${ }^{\mathbf{1 1}}$ reported that excitability of the spinal cord of the frog changes in the same way with the influence of narcosis on sugar and nitrogen metabolism. But War-

1) Mosso, Die Temperatur d. Gehirns. Ixipzig 1899.

2) Berger, Untersuchung ü. d. Temperatur d. Gehirns. Jena 1910.

3) Rolleston, Journ. Physiol., 1890, 11, 208.

4) Hill and N abarro, Tbid. 1895, 18, 218.

5) Alexander and Révész, Bioch. Zeitschr., 1912, 44, 95.

6) Alexander, Ibid. 127.

7) Winterstein, Zentralbl. f. Physiol., 1908, 21, 869.

8) Verworn, Arch. f. (Anatom. u.) Physiol, 1900, Suppl. 152. Deutsche merl. Wochenschr., 1909, 1593.

9) Mansfeld, Pflüger's Arch., 1909, 129, 69.

10) Alex ander and Cserna, Bioch. Zeitschr., 1913, 53, 100.

11) Hirschberg and Winterstein, Zeitschr. f. physiol. Chem., 1917, 100, 185. 
burg' noticing that in the eggs of ecchinoidea the oxidation is unchanged while their segmentation was restrained by phenyl urethane, denied the significance of the disturbance of oxidation for the narcosis. In Rohde and $O$ gawa's ${ }^{2}$ experiments on warm-blooded animals the action of the heart sank under chloral hydrate always far more than its oxygen consumption. Winterste in ${ }^{3}$ recognized that contrary to the decreasing excitability of the spinal cord of the frog during alcohol narcosis, oxygen consumption iucreased.

According to these reports, it may be inferred that the excitation and oxidation of the organ cells are not always influenced in the same way, and that there is not always close functional connection between paralysis and the decline of oxidation. It is then put on question what is the relation between functional activity and oxygen exchange in the brain. Hitherto very few direct observations of gaseous metabolism in the brain itself have been made. The mechanism of gaseous metabolism in the changed activity of the brain cells from various causes may show its own special feature in each case and at each time. In the present investigation I have attempted to make all these relation clear and to study how not only narcotics of varions kinds, but also hypnotics and stimulants, influence the gaseous exchange in the brain.

All narcotics in small doses have a stimulating action on the brain (the exciting stage of narcosis). Baer and Meyerstein $n^{4)}$ in the case of the liver and Winterstei ${ }^{33}$ in the case of the spinal cord, proved the increase in oxygen consumption in such a stage. Also Tashiro and Adams $\mathrm{s}^{5 j}$ observed in the nerve of the claws of libinia that $\mathrm{CO}_{2}$ production increased twice as much when it is in a $1 \%$ solution of ethyl urethane and also some increase in a $0.4 \%$ solution of chloral hydrate. In the case of the brain Alexander and Cserna ${ }^{7)}$ reported only a few cases in which the oxygen exchange increased at the beginning of magnesium narcosis. Now my first object is to investigate the gaseous metabolism in the brain at the prenarcotic stage of narcosis, and to compare it with that due to the stimulants, and further to discuss the cause of the excitation in narcosis.

1) Wa rburg, Zeitschr. f. physiol. Chem., 1910, 66, 305.

2) Rohde and $O g$ a wa, Arch. f. exp. Pathol. 1. Pharmakol, 1912, 69, 200.

3) Winterstein, Bioch. Zeitschr., 1914, 61, 81.

4) Paer and Meyerstein, Arch. f. exp. Pathol. u. Pharmakol., 1910, 63, 441.

5) Tashiro and Adams, Internat. Zeitschr. f. phys.-chem. Biol., 1914, 1, 450.

6) Alexander and Cserna, l.c. 
Next, an important and interesting question is the activity of the brain vessels. All the capillaries, especially those of the brain vessels, have been considered to change their calibre passively, but recent physiologists maintain that the capillaries have their own activity. Krog $h^{1)}$ observing that many capillaries in the resting muscles contracted and were empty, but on the contrary opened in the acting ones, stated that they might actively dilate and contract for the regulation of the blood supply to meet the demands of the tissues.

There are various arguments about the existence of vasomotor nerves in the brain and the mechanism of the changes in volume of the brain vessels, but as the blood circulation itself in the brain may probably have a close relation to the gaseous exchange in its resting and acting states, I have also studied the influence of drugs which act on the blond circulation, preparations of endocrine organs and some physical stimuli on gaseous exchange and the blood flow of the brain.

Lastly another question is: In which group is the central nervous system to be classified with regard to gaseous requirements. Some authors divide the tissues according to the behaviour of their gaseous metabolism into four groups: glandular, muscular, connective and nervous. Or should the nervous tissues really be classified as a independent group? Barcroft and Müllers pointed out that in the muscles, when the blood flow through them increased gaseous exchange also increased, whilst in the glandular tissues, for example in the submaxillary gland, the rise in the blood flow, so far as no increased secretion of saliva took place, did not cause any measurable change in the oxygen quantity used by the gland. Really it should be a matter of considerable interest to decide on the base of experimental data, whether or not increased blood flow through the brain causes increased consumption of oxygen.

Method of Experiments. The animals employed in this research were rabbits. It is an extraordinarily difficult problem to estimate the absolute amount of blood circulating through the brain, because the blood leaves the brain through various and inaccessible ways; but the object of my researches is not to find the absolute amount of gaseous exchange in the brain, but to know its change during states of rest and activity. But for this purpose we must ascertain the change in the

1) K rog h, Journ. Physiol., 1919, 52, 409.

2) Barcroft and Müller, Journ. Physiol., 1912, 44, 259. 
gas amount and the mass movement of blood through the brain during a fixed time.

The oxygen use in the brain was measured, determining by means of Barcroft's differential blood gas apparatus ${ }^{1)}$ the difference between the quantities of oxygen contained in 1 c.c. of the arterial blood and 1 c.c. of the venous blood coming ont of the brain. In the rabbit, it is rather hard to collect the venous blood flowing out through the entire brain. In the case of dogs $\mathrm{Hill}$ and $\mathrm{Nabarro} \mathrm{r}^{2}$ collected blood from the superior longitudinal sinus. At first I tried it after the method of Hill and $\mathrm{Nabarro}$, on about more than ten dogs and cats, but great haemorrhage and exposure of the nervous tissues arising from trepaning the skull bone often caused the death of the animals, and I found this method unsuitable for my investigation. When the brain is exposed to sight, not only the function of the nervous cells but also the blood circulation is often influenced by direct mechanical stimuli, the change in temperature and other physical factors. In my experiments the venous blood of the brain was taken, without exposing the skull bone and brain, from the superficial temporal vein, a branch of the external jugular vein which develops in rabbits relatively largely in compensation to the small internal jugular vein and stands in direct connection with the transversal sinus through temporal emissarium. The external ophthalmic vein and all other venous branches which communicate with the temporal emissarium and the superficial temporal vein were tied up strictly except one from the transversal sinus, so that the blood now taken from the superficial temporal vein was almost the only blood coming out from the brain.

The rate of blood flow was measured as follows: Records are given on a moving drum associated with Jaquet's watch at every moment where the meniscus of the blood column passes each $0 \cdot 1$ c.c. mark of the 2 c.c. pipette which is in connection with the cannula inserted into the central part of the superficial temporal vein and serves to collect the blood sample whose oxygen content is to be estimated. In order to obtain true and concordant readings the pipette and the cannula were always fixed in the same sitnation throughout the experiment and the velocity of the first portion of every blood column coming into the pipette from the cannula was not measured, as it might have a different rate of flow owing to the stagnation.

1) Barcroft, The Respiratory Function of Blood, Cambridge 1914.

2) Hill and Nabarro, l. c. 
Other cannulae were placed in the femoral artery of each side, one for the measurement of the blood pressure, one for the withdawal of the arterial blood for gas analysis. For this purpose the fenoral artery was chosen, because the gaseous contents of the carotid and femoral blood are practically the same and the manipulation with the carotid blood might have some interference with the circulation in the brain.

The wall of the pipettes for collecting both arterial and venous blood samples was wet with $1 \%$ solution of potassium oxalate in a very thin film to hinder the coagulation of the blood. There were no anaesthetics employed. The observation of the rate of blood flow and the collection of the blood samples were begun in 20-30 minutes after the operation was completed.

Close attention was paid to the respiration, the pulse and the general state of the animals thronghout the experiments.

\section{ETHER.}

In all of the experiments ether was administered by inhalation; a mask covered with gauz and cotton-wadding of about $3 \frac{1}{2} \mathrm{~cm}$. diameter and of $7 \mathrm{~cm}$. thickness was fixed at a distance of $1 \mathrm{~cm}$. from the nasal orifice, and ether was dropped on it at a rate of 50 drops per minute. Now observing the pupils, the corneal reflex, sense of pain, blood pressure, respiration, cardiac apex beat etc., biood samples were taken at each period of narcosis. The results are given in the following tables (Table 1-II). 


\section{Prenarcotic stage}

TABLE

$\Delta 0_{2} \ldots$.... Difference between th quantities of oxygen contained in arterial and venous blood in volume $\%$.

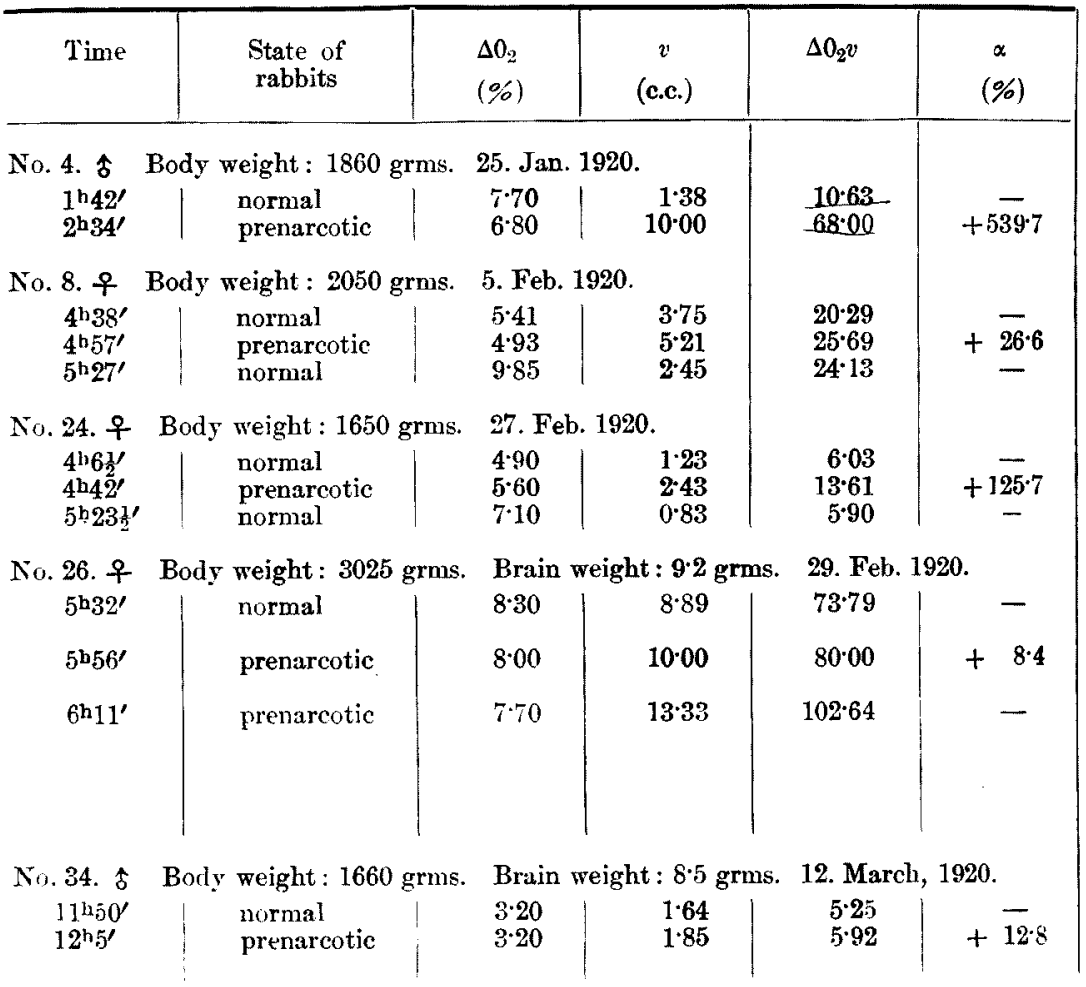

TABLE

\begin{tabular}{|c|c|c|c|c|c|}
\hline Time & $\begin{array}{l}\text { State of } \\
\text { rabbits }\end{array}$ & $\begin{array}{l}\Delta 0_{2} \\
(\%)\end{array}$ & $\begin{array}{c}v \\
\text { (c.c.) }\end{array}$ & $\Delta 0_{2} v$ & $\begin{array}{c}\alpha \\
(\%)\end{array}$ \\
\hline No. 19. 우 & Body weight : 295 & \multicolumn{2}{|c|}{ 22. Feb. 1920.} & & \\
\hline $12^{\mathrm{h}} 45^{\prime}$ & normal & $4 \cdot 10$ & $1 \cdot 67$ & 6.85 & - \\
\hline $1^{\mathrm{h}} 19$ & prenarcotic & $7 \cdot 10$ & $1 \cdot 65$ & $11 \cdot 72$ & $+71 \cdot 1$ \\
\hline
\end{tabular}




\section{of ether narcosis.}

$\mathbf{I} \mathbf{\Lambda}$.

$v$.........Venous blood flow in c.c. per minute.

a .........Change in oxygen consumption $\left(\Delta 0_{22} v\right)$ in $\%$.

\begin{tabular}{|c|c|c|c|c|}
\hline $\begin{array}{l}\text { Change in } v \\
\quad(\%)\end{array}$ & $\begin{array}{c}\text { Blood } \\
\text { pressure } \\
\text { (mm. Hg) }\end{array}$ & Pulse & $\underbrace{\text { Respiration }}_{5^{\prime \prime}}$ & Remarks \\
\hline$+\overline{624} 6$ & 108 & - & - & $\begin{array}{l}\text { At } 2^{\mathrm{h}} 32^{\prime}-2^{\mathrm{h}} 34^{\prime} \quad 50 \text { drops ether } \\
\text { inhaled. Vigorous excitement. }\end{array}$ \\
\hline $\begin{array}{l}\overline{38} \cdot 9 \\
-\end{array}$ & $\begin{array}{l}103 \\
134 \\
116\end{array}$ & - & E & $\begin{array}{l}\text { At } 4^{\mathrm{b}} 55^{\prime}-4^{\mathrm{b}} 57^{\prime} 60 \text { drops ether in- } \\
\text { haled. The rabbit quiet. }\end{array}$ \\
\hline$+\underline{\overline{97}} \cdot 6$ & $\begin{array}{r}100 \\
98 \\
94\end{array}$ & $\begin{array}{l}16 \\
15 \\
17\end{array}$ & $\begin{array}{r}12 \\
7 \\
12\end{array}$ & $\begin{array}{l}\text { At } 4^{\mathrm{h}} 28^{\prime \prime}-4^{\mathrm{h}} 4 \overline{3}^{\prime} 300 \text { drops ether } \\
\text { inhaled. Corneal reflex prompt. }\end{array}$ \\
\hline - & 108 & 20 & 11 & At $5^{1} 50$ pulse rate 20 , respir. 8 . \\
\hline+125 & 104 & 19 & 6 & $\begin{array}{l}\text { At } 55^{5} / 215720 \text { drops ether } \\
\text { inhaled. Corneal reflex prompt. } \\
\text { The rabbit quiet. }\end{array}$ \\
\hline 一 & 124 & 18 & 6 & $\begin{array}{l}\text { At } 6^{\mathrm{b} 9} \text { pulse rate } 18 \text {, respir. } 8 \text {. } \\
\text { At } 6^{\mathrm{h}} 10^{\prime}-6^{\mathrm{b}} 17^{\prime} 200 \text { drops ether } \\
\text { inhaled. Corneal reflex prompt. } \\
\text { Pupils a little larger. The rabbit } \\
\text { moving. }\end{array}$ \\
\hline$+\overline{12 \cdot 8}$ & $\begin{array}{l}114 \\
112\end{array}$ & $\begin{array}{l}20 \\
14\end{array}$ & $\begin{array}{r}10 \\
5\end{array}$ & $\begin{array}{l}\text { At } 12 \mathrm{~h} 2^{\prime}-12^{\mathrm{h}} 6^{\prime} 4 \text { c.c. ether inhaled. } \\
\text { Corneal reflex positive. }\end{array}$ \\
\hline
\end{tabular}

I, B.

\begin{tabular}{|c|c|c|c|c|}
\hline $\begin{array}{c}\text { Change in } v \\
(\%)\end{array}$ & $\begin{array}{c}\text { Blood } \\
\text { pressure } \\
\text { (mm. Hg) }\end{array}$ & $\underbrace{\text { Pulse }}_{p}$ & $\underbrace{\text { Respiration }}_{5^{\prime \prime}}$ & Remarks \\
\hline- & 134 & 13 & 3 & $\begin{array}{l}\text { At } 1^{\mathrm{h}} 12^{\prime}-1^{\mathrm{h}} 19^{\prime} \quad 200 \text { drops ether } \\
\text { inhaled. }\end{array}$ \\
\hline-1.2 & 136 & 16 & 3 & $\begin{array}{l}\text { Corneal reflex prompt. Pupils } \\
\text { normal. The animal not quiet. }\end{array}$ \\
\hline
\end{tabular}


Table

\begin{tabular}{|c|c|c|c|c|c|}
\hline Tine & $\begin{array}{l}\text { State of } \\
\text { rabbits }\end{array}$ & $\begin{array}{l}\Delta 0_{2} \\
(\%)\end{array}$ & $\begin{array}{c}v \\
\text { (c.c.) }\end{array}$ & $\Delta 0_{2} v$ & $\begin{array}{c}* \\
(\%)\end{array}$ \\
\hline No.9. $\$$ & Body weight: 1760 & 19. Ja & & & \\
\hline $\begin{array}{l}3 \mathrm{hy} \mathrm{g}^{\prime} \\
4^{\mathrm{h}} \mathrm{g}^{\prime}\end{array}$ & $\begin{array}{l}\text { normal } \\
\text { prenarcotic }\end{array}$ & $\begin{array}{l}5 \cdot 80 \\
580\end{array}$ & $\begin{array}{l}4 \cdot 65 \\
4 \cdot 67\end{array}$ & $\begin{array}{l}26 \cdot 97 \\
27.09\end{array}$ & $+\overline{0.4}$ \\
\hline $5^{\mathrm{h}}+6^{\prime}$ & narcotic & $5 \cdot 10$ & $37 t$ & $19 \cdot 28$ & $-28 \cdot 7$ \\
\hline
\end{tabular}

TABLE

\begin{tabular}{|c|c|c|c|c|c|c|}
\hline Time & & $\begin{array}{l}\text { State of } \\
\text { rabbits }\end{array}$ & $\begin{array}{l}\Delta 0_{2} \\
(\%)\end{array}$ & $\begin{array}{c}v \\
\text { (c.c.) }\end{array}$ & $\Delta 0_{2} v$ & $\begin{array}{l}x \\
(\%)\end{array}$ \\
\hline No. 18.9 & Body & weight: 3072 grms. & 21: $\mathbf{F}$ & & & \\
\hline $12^{h} 13^{\prime}$ & & normal & $6 \cdot 40$ & $7 \cdot 50$ & $48 \cdot 00$ & - \\
\hline $12^{\mathrm{b}} \mathscr{8} 3^{\prime}$ & & premarcotic & $5 \cdot 10$ & $10 \cdot 00$ & $51 \cdot 00$ & +6.3 \\
\hline
\end{tabular}

TABLE

\begin{tabular}{c|c|c|c|c|c|}
\hline Time & $\begin{array}{l}\text { State of } \\
\text { rabbits }\end{array}$ & $\begin{array}{l}\Delta 0_{\%} \\
(\%)\end{array}$ & $\begin{array}{c}v \\
\text { (c.c.) }\end{array}$ & $\Delta 0_{2} v$ & $\begin{array}{c}\% \\
(\%)\end{array}$ \\
\hline
\end{tabular}

No. 33. \& Body weight: 1520 grnss. Brain weight: 83 grms. 10 March 1920 .

\begin{tabular}{|c|c|c|c|c|c|}
\hline $3 \ln 34^{\prime}$ & normal & $3 \cdot 10$ & $10 \cdot 48$ & $10 \cdot 48$ & - \\
\hline $3^{\mathrm{L}} 50$ & normal & 3.30 & $3 \cdot 22$ & 10.63 & +1.4 \\
\hline $4^{4} 112$ & prenareotic & 530 & 1.27 & 673 & \\
\hline
\end{tabular}

No. 35. ㅇ Body weight: 2190 grms. Brain weight : $9 \cdot 5$ grms. 13. March 1920 .
$11^{\mathrm{h}} 19^{\prime}$
normal
6.00
$5 \cdot 58$
470
$33 \cdot 48$
$24 \cdot 44 \quad-\overline{27} \cdot 0$

No. 36. $\hat{o}$ Body weight: 2100 grms. Brain weight: 9.0 grms. 13. March 1920.

\begin{tabular}{|c|c|c|c|c|c|}
\hline $4^{4} 13^{\prime \prime}$ & normal & $4 \cdot 00$ & 4.49 & 17.96 & $\overline{00.7}$ \\
\hline $4^{\mathrm{b}} 33^{\prime}$ & prenarcotic & 6.40 & $2 \cdot 00$ & 1280 & $-28 \cdot 7$ \\
\hline $4^{1+5} 8^{\prime \prime \prime} y^{\prime}$ & nareotic & $3 \cdot 10$ & $2 \cdot 33$ & $7 \cdot 22$ & -59.8 \\
\hline
\end{tabular}

No. 37. o Eody weight : 1690 grus. Brain weight : 76 grms. 16. March 1920.

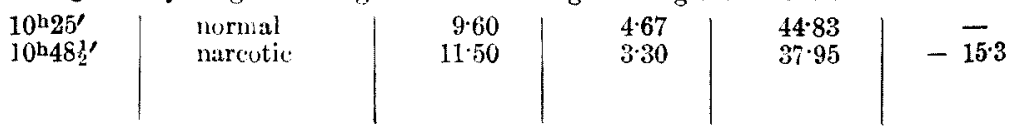


I, C.

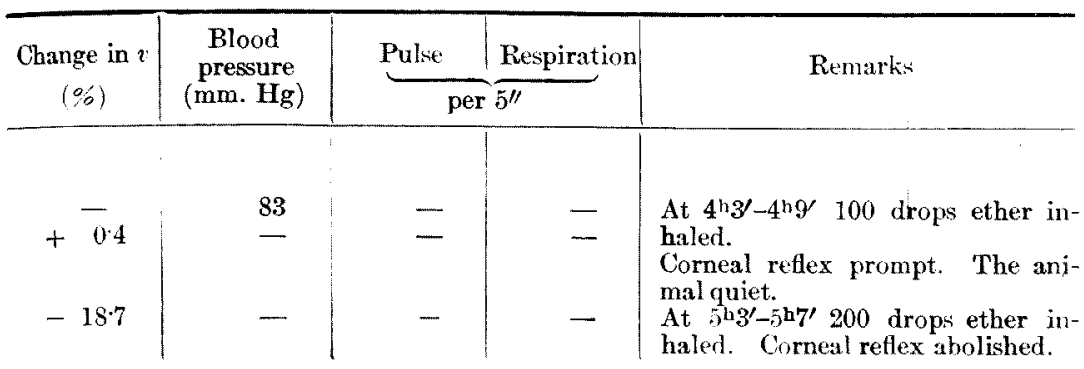

I, D.

\begin{tabular}{|c|c|c|c|c|}
\hline $\begin{array}{c}\text { Change in } v \\
(\%)\end{array}$ & $\begin{array}{c}\text { Blood } \\
\text { pressure } \\
\text { (mm. Hg) }\end{array}$ & $\underbrace{\text { Pulse }}_{1}$ & $\frac{\text { Respiration }}{5^{\prime \prime}}$ & Remarks \\
\hline - & 108 & 18 & 3 & $\begin{array}{l}\text { At } 12 \text { ho } \sigma^{\prime}-12133^{\prime} 150 \text { drops ether } \\
\text { inhaled. }\end{array}$ \\
\hline$+33 \cdot 3$ & 152 & 12 & 5 & $\begin{array}{l}\text { Corneal reflex weakened. Pupil } \\
\text { normal. The rabbit quiet. }\end{array}$ \\
\hline
\end{tabular}

I, k.

\begin{tabular}{|c|c|c|c|c|}
\hline $\begin{array}{c}\text { Change in } v \\
\left(\frac{0}{0}\right)\end{array}$ & $\begin{array}{c}\text { Blood } \\
\text { pressure } \\
(\mathrm{mm} . \mathrm{Hg})\end{array}$ & Pulse & $\frac{\text { Respiration }}{5^{\prime \prime}}$ & Remarks \\
\hline - & 100 & 20 & 10 & At $4^{1} / 8^{\prime}$ pulse rate 20 , respir. 8 . At \\
\hline+47 & 96 & 20 & 10 & $4^{\text {ha }}-4^{\mathrm{h}} 15^{\prime} 3$ c.e. ether inhaled. \\
\hline-606 & 92 & 19 & 8 & $\begin{array}{l}\text { Corneal reflex prompt. The ani- } \\
\text { mal quiet. }\end{array}$ \\
\hline - & 114 & 18 & 12 & At $11^{\mathrm{h}} 41^{\prime}$ pulse 18 , respir. 10 At \\
\hline-68 & 110 & 16 & 8 & $\begin{array}{l}11^{\prime \prime} 42^{\prime}-11^{\mathrm{b}} 46^{\prime} 3 \text { c.c. ethor inhaled. } \\
\text { Corneal reflex prompt. The an- } \\
\text { mal quiet. }\end{array}$ \\
\hline - & 126 & 20 & 11 & At $4^{\prime} 29^{\prime}$ pulse 20 , respir. 5. At \\
\hline-55.5 & 120 & 16 & 5 & $\begin{array}{l}4^{\mathrm{b}} 30 y^{\prime}-4^{\mathrm{h}} 37^{\prime} 6 \text { c.c. ether inhaled. } \\
\text { Corneal reflex prompt. The rabbit } \\
\text { quiet. }\end{array}$ \\
\hline$-48 \cdot 1$ & 112 & 17 & 6 & $\begin{array}{l}\text { At } 4^{\mathrm{b}} 55^{\prime}-5^{\mathrm{h}} 3^{\prime} 5 \text { c.c. ether inhaled. } \\
\text { Corneal reflex scarcely provoked. }\end{array}$ \\
\hline$-\overline{29 \cdot 3}$ & $\begin{array}{r}110 \\
96\end{array}$ & $\begin{array}{l}20 \\
14\end{array}$ & $\begin{array}{c}5 \\
4 \\
(\operatorname{deep})\end{array}$ & $\begin{array}{l}\text { At } 10^{h} 45^{\prime}-10^{\mathrm{h}} 51^{\prime} \quad 2.5 \text { c.e. ether } \\
\text { inhaled. } \\
\text { The animal quiet. Corneal reflex } \\
\text { prompt. }\end{array}$ \\
\hline
\end{tabular}


Narcotic stage of

TABLE

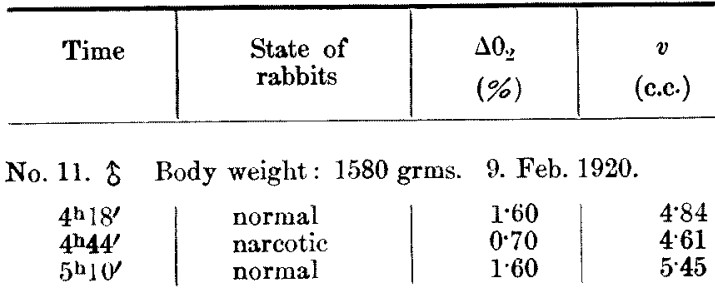

No. 12. 우 Body weight: 2030 grms. 10 . Feb. 1920 .

\begin{tabular}{l|l|l|l}
$10^{\mathrm{h}} 2 \%$ & normal & $5 \cdot 80$ & $5 \cdot 85$ \\
$10^{\mathrm{h}} 54^{\prime}$ & narcotic & $2 \cdot 90$ & $5 \cdot 73$ \\
& & & \\
$11^{\mathrm{b}} 25^{\prime}$ & normal & $9 \cdot 20$ & $3 \cdot 24$
\end{tabular}

No. 15. 우 Body weight : 2430 grms. 13. Feb. 1920 .

\begin{tabular}{l|l|l|r}
$2^{\mathrm{h}} 23^{\prime}$ & normal & $5 \cdot 70$ & $9 \cdot 23$ \\
$3^{\mathrm{h}} 58^{\prime}$ & narcotic & $5 \cdot 30$ & $8 \cdot 69$ \\
$4^{\mathrm{h}} 30^{\prime}$ & prenarcotic & 530 & $11 \cdot 70$
\end{tabular}

No. 17. + Body weight: 2410 grms. 15. Feb. 1920 .

\begin{tabular}{l|l|l|r}
$10^{\mathrm{b}} 21 \mathrm{y}^{\prime}$ & normal & 4.80 & 11.25 \\
$10^{\mathrm{n} 5} 58^{\prime}$ & prenarcotic & 6.90 & 12.63 \\
$11^{\mathrm{h}} 32^{\prime}$ & narcotic & 4.00 & 6.59
\end{tabular}

No. 21. 우 Body weight: 2880 grms. 24. Feb. 1920 .

\begin{tabular}{l|l|r|r|}
$10^{\mathrm{h}} 34^{\prime}$ & normal & $10 \cdot 37$ & $4 \cdot 17$ \\
$11^{\mathrm{b}} 6^{\prime}$ & nareotic & $8 \cdot 15$ & 2.08 \\
$11^{\mathrm{b}} 50^{\prime}$ & normal & 10.07 & 1.87
\end{tabular}

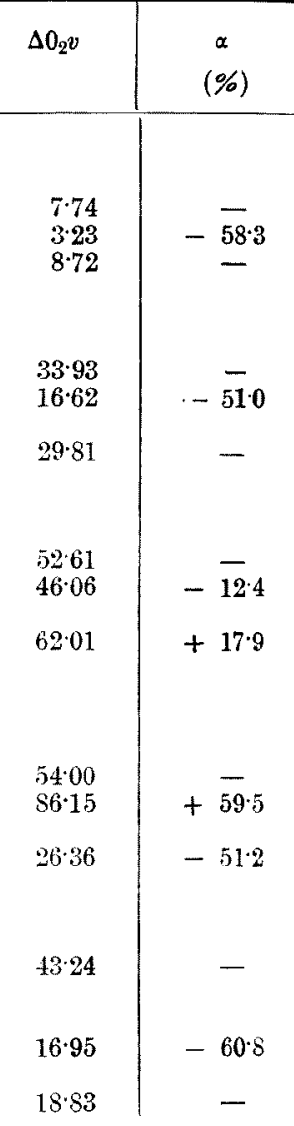

No. 25. 우 Body weight: $1800 \mathrm{grms}$. Brain weight: $90 \mathrm{grms}$. 28. Feb. 1920 .

\begin{tabular}{l|l|l|l|l|l}
$3^{\mathrm{h} 25^{\prime}}$ & normal & 7.30 & 328 & 23.94 & - \\
$4^{\mathrm{h}} 4^{\prime}$ & narcotic & 6.80 & 235 & 15.98 & -34.0 \\
$4^{4} 48^{\prime}$ & narcotic & 680 & 204 & 13.87 & -
\end{tabular}

No. 32. 实 Body weight: 1730 grms. Brain weight : 9.3 grms. 9. March 1920.

\begin{tabular}{|l|l|l|l|l|l|}
$3^{\mathrm{b}} 39^{\prime}$ & normal & $6 \cdot 40$ & $13 \cdot 33$ & $85 \cdot 31$ & - \\
$4^{\mathrm{b}} 192^{\prime}$ & nareotic & $3 \cdot 60$ & $8 \cdot 00$ & $28 \cdot 50$ & $-66 \cdot 2$ \\
$4^{\mathrm{h}} 50^{\prime}$ & normal & $6 \cdot 20$ & $7 \cdot 87$ & $48 \cdot 79$ & -
\end{tabular}




\section{Ether Narcosis.}

II, A.

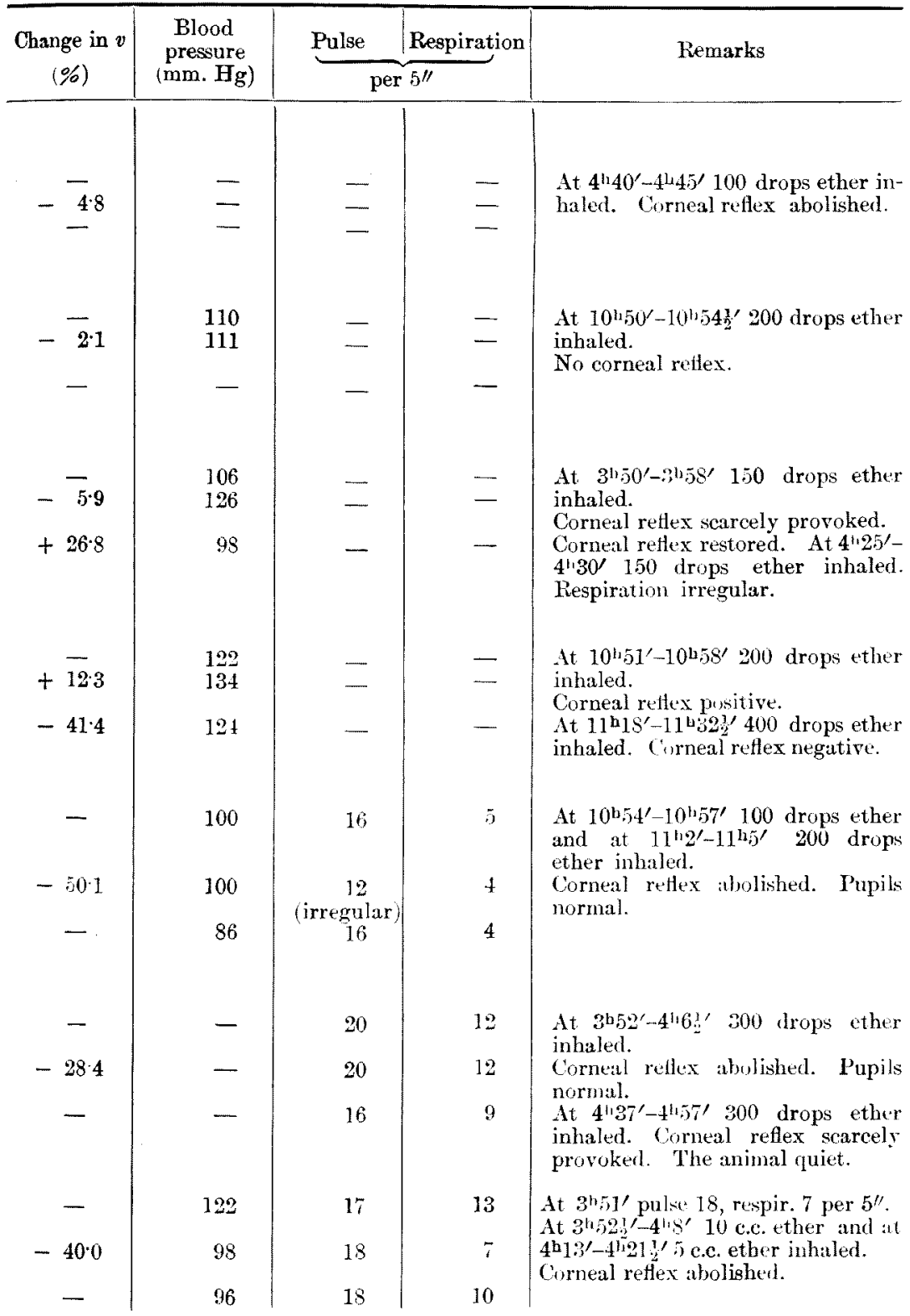


TabLE

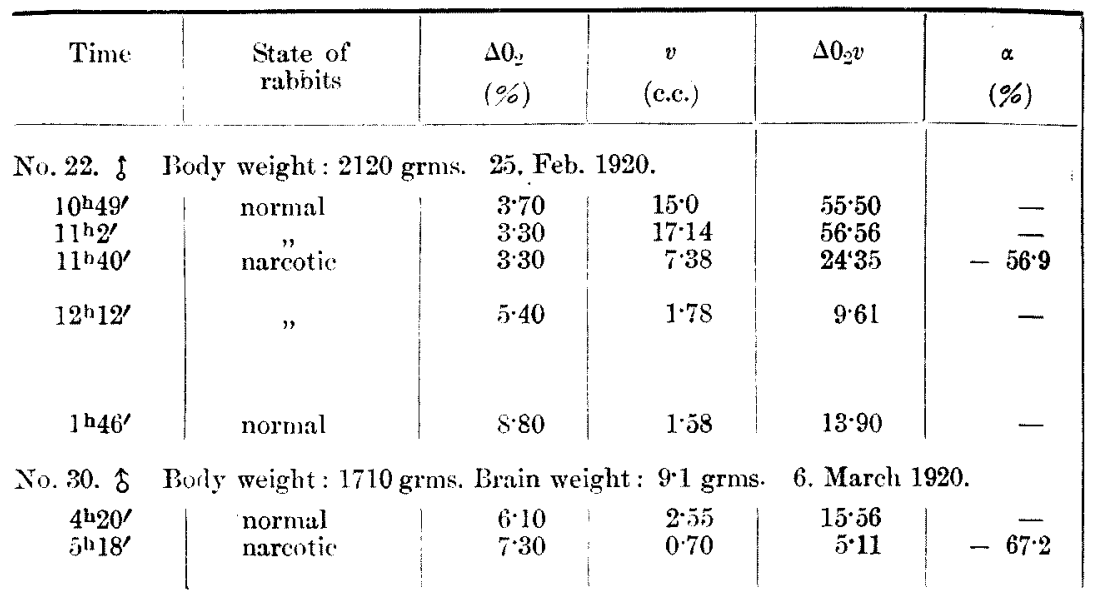

TABLE

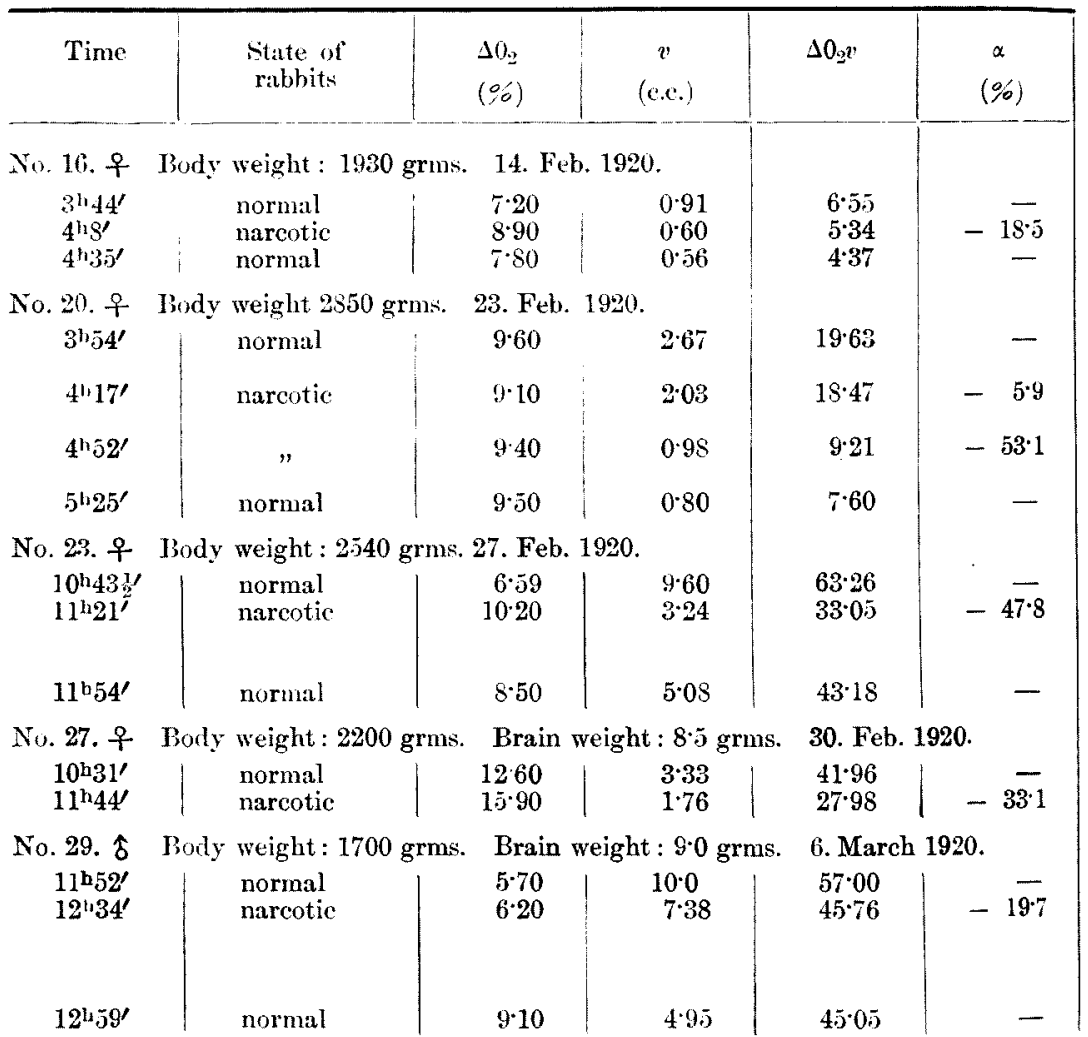


II, $\mathbf{B}$.

\begin{tabular}{|c|c|c|c|c|}
\hline $\begin{array}{c}\text { Change in } v \\
(\%)\end{array}$ & $\begin{array}{c}\text { Blood } \\
\text { pressure } \\
(\mathbf{m m} . \mathrm{Hg})\end{array}$ & $\underbrace{\text { Pulse }}_{\text {per }}$ & $\frac{\text { Respiration }}{5^{\prime \prime}}$ & Remarks \\
\hline - & s8 & 19 & 11 & 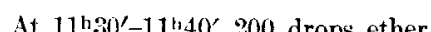 \\
\hline$\overline{50.0}$ & 86 & 19 & 11 & inhaled. Pupils large. Corneal re- \\
\hline-56.9 & 88 & $\begin{array}{c}10 \\
\text { (irregular) }\end{array}$ & 4 & flex weak. The ratbit quiet. \\
\hline - & 58 & $\begin{array}{c}16 \\
\text { (regular) }\end{array}$ & 4 & $\begin{array}{l}\text { At } 12^{\mathrm{h}} 4^{\prime} \text { pulse } 20 \text {, respir. } 9 . \\
\text { At } 12^{\mathrm{h}} 5^{\prime}-12^{\mathrm{h}} 12^{\prime} 200 \text { drops ether } \\
\text { inhaled. Corneal reflex weakened. } \\
\text { Pupils normal. The rabbit awiet. }\end{array}$ \\
\hline - & 48 & 17 & 8 & \\
\hline$-7 \overline{25}$ & 122 & $\begin{array}{c}18 \\
\stackrel{b}{(i r r e g u l a r)}\end{array}$ & $\begin{array}{c}9 \\
4 \\
(d e c y)\end{array}$ & $\begin{array}{l}\text { At } 5^{\mathrm{b}} 6^{\prime}-5^{\mathrm{b}} 22^{\prime} \\
\text { Comeal rece ether inhaled. } \\
\text { abolished. }\end{array}$ \\
\hline
\end{tabular}

II, c.

\begin{tabular}{|c|c|c|c|c|}
\hline $\begin{array}{l}\text { Change in } v \\
\text { (\%) }\end{array}$ & $\begin{array}{c}\text { Blood } \\
\text { pressure } \\
(\mathrm{mm} . \mathrm{Hg})\end{array}$ & $\frac{\text { Pulse }}{\text { per }}$ & $\frac{\text { Respiration }}{5^{\prime \prime}}$ & Remarks \\
\hline & & & & \\
\hline$-\overline{34 \cdot 1}$ & $\begin{array}{r}110 \\
88 \\
\end{array}$ & - & $\overline{-}$ & $\begin{array}{l}\text { At } 4^{\mathrm{l}} 1^{\prime}-4^{\mathrm{h}} 83^{\prime} 200 \text { drops ether in } \\
\text { haled. Curneal rettex abolished. }\end{array}$ \\
\hline 一 & 124 & 19 & 14 & At $4^{110 /}-4^{\mathrm{b}} 17^{\prime} 200$ drops ether in- \\
\hline$-24 \cdot 0$ & 126 & $\begin{array}{l}12 \\
\text { (irregular) }\end{array}$ & 5 & $\begin{array}{l}\text { Corneal reflex weakened. Pnpils } \\
\text { normal. The animal quiet. }\end{array}$ \\
\hline$-63 \cdot 3$ & 90 & 17 & 6 & $\begin{array}{l}\text { At } 4^{\mathrm{h}} 49^{\prime}-4^{\mathrm{h}} 53^{\prime} 250 \text { drops ether in- } \\
\text { haled. Corneal reflex weakened. }\end{array}$ \\
\hline$\rightarrow$ & 80 & 17 & 7 & \\
\hline$\frac{1}{60 \times 0}$ & 104 & 18 & 10 & At $11^{\text {hg }}$ pulse 17 , respir. 10 \\
\hline-663 & 104 & 14 & 4 & $\begin{array}{l}\text { At } 11^{\mathrm{h}} 10^{\prime}-11^{\mathrm{h}} 24^{\prime} 200 \text { drops ether } \\
\text { inhaled. Corneal refiex weaken- } \\
\text { ed. Pupis large. }\end{array}$ \\
\hline- & 64 & 17 & 10 & \\
\hline$-4 \overline{7 \cdot 1}$ & 118 & $\begin{array}{l}19 \\
14\end{array}$ & $\begin{array}{r}12 \\
6\end{array}$ & $\begin{array}{l}\text { At } 11^{\mathrm{b}} 43^{\prime}-11^{\mathrm{h}} 46^{\prime} 150 \mathrm{drops} \text { ether } \\
\text { inhaled. } \\
\text { Corneal reflex weakened. }\end{array}$ \\
\hline - & 112 & $2 t$ & 10 & At $12^{1125^{\prime}}$ pulse 20 , respir. 10 . \\
\hline$-26 \cdot 2$ & 144 & 16 & 5 & $\begin{array}{l}\text { inlualed } 30 \text { drops per minute). } \\
\text { Corneal rettex weakened. The rab- } \\
\text { bit quiet. }\end{array}$ \\
\hline 一 & 一 & 20 & 5 & \\
\hline
\end{tabular}




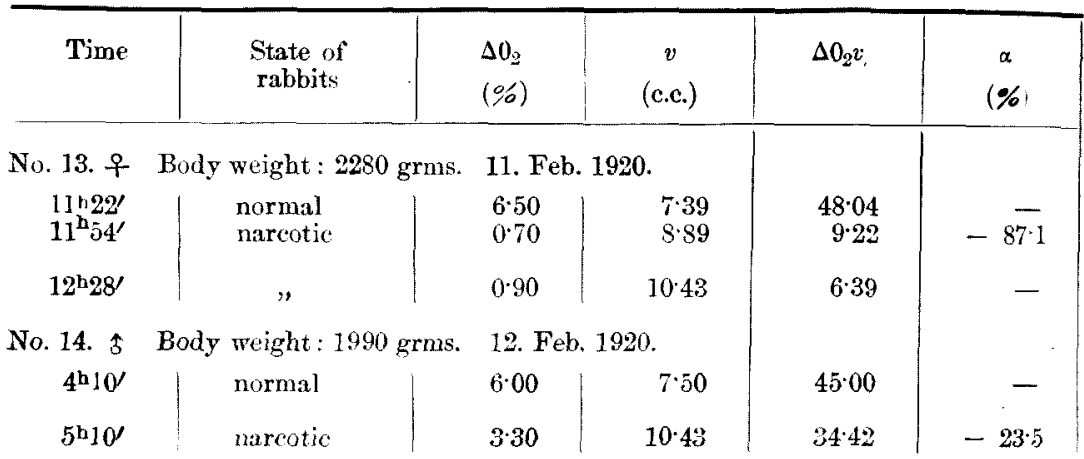

'The prenarcotic and narcotic stages were distinguished according to the existence and non-existence of corneal reflex.

Serveying the results of these experiments it is found that at the prenarcotic stage (14 experiments, Tables I \& II, A, Exp. 15 \& 17), both oxygen consumption and blood flow of the brain increased; in most cases they were parallel to each other (Exp. 4, 8, 24, $26 \& 34$ ). There was one case (Exp. 17) in which the rate of increase in oxygen consumption was greater than that in blood flow, and one case (Exp. 15) in which the former was less, and one case (Exp. 19) in which only the oxygen consumption increased withont any change in the blood flow.

Out of 14 experiments at the prenarcotic stage two showed no change ii oxygen consumption at the prenarcotic stage, but in one of the two there was no change in blood flow, in the other it was accelerated (Exp. $9 \&$ 18). In 4 out of 14 cases the oxygen consumption and blood flow decreased. In 3 cases of the four the degree of the decrease in the oxygen consumption was far less than that in the blood flow, while in the remaining one the relation of them was just the reverse (Tab. I, E). There were only two cases (Exp. $17 \& 19$ ), where the increase in oxygen consumption at the prenarcotic state seemed to be independent of the blood flow, showing an abnormal rise of the excitability of the nerve cells. Generally at the prenarcotic stage, the more the blood flow increased and the more remarkably the animal seemed excited the greater was the increase in gaseous exchange and when the rabbit becume narcotic and its corneal reflex was weaker, both the oxygen consumption and the blud flow gradually diminished.

In short, at the prenarcotic stage the change in cerebral oxygen cou- 
II, D.

\begin{tabular}{|c|c|c|c|c|}
\hline $\begin{array}{c}\text { Change in } v \\
(\%)\end{array}$ & $\begin{array}{c}\text { Blood } \\
\text { pressure } \\
(\mathrm{mm} . \mathrm{Hg})\end{array}$ & $\underbrace{\text { Pulse }}_{p}$ & $\frac{\text { Respiration }}{5^{\prime \prime}}$ & Remarks \\
\hline$+2 \overline{0 \cdot 3}$ & 126 & - & - & At $11^{\mathrm{b}} 49^{\prime}-11^{\mathrm{b}} 55^{\prime} 150$ drops ether \\
\hline - & 136 & - & - & $\begin{array}{l}\text { Corneal reflex abolished. } \\
\text { At } 122^{2} 23^{\prime}-12^{\mathrm{b}} 39^{\prime} 180 \text { drops ether } \\
\text { inhaled. Corneal reflex abolished. }\end{array}$ \\
\hline$+39 \cdot 1$ & $\begin{array}{r}88 \\
118\end{array}$ & - & - & $\begin{array}{l}\text { At } 5^{\mathrm{h}} 3^{\prime}-5^{\mathrm{h}} 10^{\prime} 230 \text { drops ether } \\
\text { inhaled. } \\
\text { Corneal reflex abolished. }\end{array}$ \\
\hline
\end{tabular}

sumption due to ether depends generally on that in the blood flow in the brain. In most of the experiments they increased together, except in few cases, in which the reduction of the oxygen consumption has been observed, probably as a result of the abnormal decrease in the blood flow rather than the changed function of the central nerve cells. The change in the blood flow did not run parallel to that in the corneal reflex.

At the narcotic stage, there was a decrease in the oxygen consumption in all the 18 cases; on an average the decrease was $51.6 \%$ $(12 \cdot 4-87 \cdot 1 \%)$. If $\mathrm{SO}_{2}$ be the difference between the quantities of oxygen contained in arterial and venous blood in volume $\%, v$ the blood flow in c.c. per minute, and $\alpha$ the change in oxygen exchange $\left(\Delta \mathrm{O}_{2} v\right)$ after the anaesthesia in $\%$, then

$$
\alpha=\frac{\left(\Delta 0_{2} v\right) \text { normal }-\left(\Delta 0_{2}^{\prime} v^{\prime}\right) \text { narcotic }}{\left(\Delta 0_{2} v\right) \text { normal }} .100
$$

Here at the narcotic stage, $\alpha$ is $51.6 \%$ on an average. Alex ander and Csern $a^{1)}$ observed a decrease of $77 \cdot 2 \%$ in the dog.

The volume velocity of the blood flow, as mentioned above was generally accelerated at the prenarcotic stage, on the other hand at the narcotic stage it decreased in nearly all cases except two (Exp. 13 \& 14), in which it increased. Even in these two cases the oxygen consumption was reduced. The rate of the decrease in the oxygen consumption was mostly greater than that in the blood flow (Exp. 9, 11, 12, 15, 17, 21, $25,32 \& 36$ ) ; in 5 other cases (Exp. 16, 20, 23, $27 \& 29$ ), in which the paralysis was considered to be relatively slight in comparison with the

1) Alexaader and Cserna, l.c. 
others, the corneal reflex being, though weakly, positive, it was on the contrary less than the latter, whilst in Exp. 22 and 30 they were parallel to each other. In general the deeper the narcosis and the slower the blood flow the greater the rate of the decrease in the oxygen consumption. Namely, the decrease in the oxygen consumption observed at the narcotic stage may be attributed to the depressant effect of the anaesthetic on the cerebral nerve cells themselves, though in part it is due to the change in the blood flow.

At the stage of reconvalescence the oxygen consumption began again to grow together with the revival of activity of the brain, though far less than the normal value except in Exp. 11, in which the rate of the oxygen metabolism regained its former height. On the other hand, the rate of the blood flow hardly returned to its normal value. There were three cases (Exp. 16, $20 \& 29$ ), in which the oxygen consumption did not revive owing to the excessively decreased blood flow. It is highly probable that at this stage the oxygen consumption did not regain its normal value in spite of the revival of the cerebral function, because the blood flow was not completely restored, owing to the action of ether on the brain circulation, the fall of the arterial blood pressure or the emaciation of the animals due to repeated withdrawal of blood. Thus, there is a different feature in the gas exchange of the brain at each period of ether anaesthesia. I will later discuss this more fully on comparing it with the action of chloroform.

Concerning the influence of ether on the brain circulation Bayliss and $\mathrm{Hill}^{1)}$ maintained that the venous blood pressure in the brain decreased merely as the result of the fall of the arterial pressure, and Roy and Sherrington ${ }^{2)}$ proved that on ether inhalation a primary contraction, lasting for a varying time, was followed by well marked expansion of the brain, while $\mathrm{Pick}^{3}$ observed in dogs no distinct descent in the arterial blood pressure at the paralytic stage, but always a noticeable increase in the rate of blood flow through the jugular vein, which was parallel to the fall of the blood pressure, and Berezin ${ }^{4}$ demonstrated the dilation of the cerebral vessels.

In my experiments the effects at the prenarcotic stage show some different features from those at the narcotic stage; in the former the

1) Ba y liss and Hill, Journ. Physiol., 1895, 18, 334.

2) Roy and Sher ring to n, Ibid. $1890,11,85$.

i) Pick, Arch. f. exp. Pathol. u. Pharmakol,, 1899, 42, 399.

4) Berezin, Russkiy Vrach, 1916, 15, 513. Cited in Joum. Amer. Med. Assoc, $1916,67,844$. 
blood flow generally increased and in the latter it decreased. In order to determine what the change in the blood flow causes we must first know the relation between the blood flow and the arterial blood pressure.

Out of 12 cases at the prenarcotic stage there are three cases (Exp. $24,26 \& 34$ ) in which the blood pressure was unchanged, but the blood flow increased ; four cases (Exp. 8, 17, $18 \& 26$ ), in which both the blood pressure and the blood flow increased; one case (prenarcotic stage of Exp. 15) in which the blood pressure slightly fell and the blood flow increased ; two cases (Exp. $19 \& 35$ ) which showed no change either in the blood pressure or in the blood flow, and three cases (Exp. 33, $36 \&$ 37) in which the decrease in the blood flow was accompanied by the descent of blood pressure. Next, out of 13 cases at the narcotic stage four cases $\left(\mathrm{Exp}_{x \mathrm{P}}\right.$ 17, 21, $\left.22 \& 23\right)$ in which there was no change in the blood pressure but a decrease in the blood flow; one case (Exp. 15) with a rise of the arterial pressure, but with no change in the blood flow; one case (Exp. 29) in which the blood flow decreased in spite of the rise of blood pressure ; four cases (Exp. 16, 20, 32 \& 36) in which the fall of the blood flow was too great in comparison with the descent of the blood pressure. Besides there were two cases (Exp. $13 \& 14$ ) in which the corneal reflex disappeared, but the level of the blood pressure still remained high like that at the exciting stage, accompanied by acceleration of the blood flow, and lastly one case (Exp. 12) in which the blood flow did not change and the blood pressure kept the normal height.

In short, at the prenarcotic stage the change in the blood flow was accompanied sometimes by that in the arterial blood pressure, but sometimes the blood flow was markedly accelerated even when the blood pressure did not change or decreased. This led me to believe with Pick ${ }^{1}$ that the cerebral vessels can actively dilate. At the narcotic stage too, in some cases the blood flow followed the changes in the arterial blood pressure, but generally it decreased, although the blood pressure was unaltered or even raised, at least showing no corresporiding fall. This is most presumably due to the active contraction of the cerebral vessels at the later stage of anaesthesia.

Moreover, the change in the cerebral vessels may be affected by an alteration of pulse, respiration and movement of the animals and their passive dilation and consequent increase in the blood flow may follow the rise of the general venous blood pressure due to the arterial fall of a high degree. Throughout all my experiments these factors were

1) Pick, l. c. 
considered as much as possible, but it can presumably be maintained that ether acts on the cerebral vessels primarily as a dilator, and then causes the vasoconstriction which continues until after the narcosis is over. Besides the changes in the cerebral vessels depend partly upon the change in the arterial blood pressure at each stage of narcosis.

\section{ChLoroform.}

Chloroform, when inhalted, in the early stage of narcosis produced almost a stoppage of respiration, the rate becoming one for five seconds, and the cardiac apex beat was also suspended and irregular, 4-5 beats for every five seconds. Moreover, excitement, struggling and increased salivary secretion were observed. The pupils dilated when the corneal reflex disappeared and the animal became quiet. By and by the rate of respiration increased, but always still less than that before the administration of the chloroform and the pulse rate also became

Prenarcotic stage of

TABLE

\begin{tabular}{|c|c|c|c|c|c|c|}
\hline Time & & $\begin{array}{l}\text { State of } \\
\text { rabbits }\end{array}$ & $\begin{array}{l}\Delta \theta_{2} \\
(\%)\end{array}$ & $\begin{array}{c}v \\
\text { (c.c.) }\end{array}$ & $\Delta 0_{2} v$ & $\begin{array}{l}\alpha \\
(\%)\end{array}$ \\
\hline No.15. 우 & Body & weight : 2272 grms. & Brain & ht: 9.0 grms. & 21. Mas & \\
\hline $1 \ln 1 \tilde{5}^{\prime}$ & & normal & 307 & 522 & 1603 & - \\
\hline $11^{h} 52^{\prime}$ & & prenarcotic & 233 & $8 \cdot 14$ & $18 \cdot 97$ & $+18 \cdot 3$ \\
\hline $12^{1} 24 y^{\prime}$ & & nareotic & $3 \cdot 93$ & $2 \cdot 30$ & $9 \cdot 04$ & -437 \\
\hline No. 1S. \& & Body & weight : 1710 grms. & Brain & ht $9 \cdot 4$ grms. & 28. May & \\
\hline $\begin{array}{l}10^{\mathrm{h}} 19^{\prime} \\
10^{\mathrm{h}} 40^{\prime}\end{array}$ & & $\begin{array}{l}\text { normal } \\
\text { prenarcotic }\end{array}$ & $\begin{array}{l}9 \cdot 78 \\
5 \cdot 70\end{array}$ & $\begin{array}{l}2 \cdot 03 \\
6 \cdot 99\end{array}$ & $\begin{array}{l}19 \cdot 85 \\
39 \cdot 84\end{array}$ & $\begin{array}{r}\overline{-} \\
+1007\end{array}$ \\
\hline
\end{tabular}

TABLE

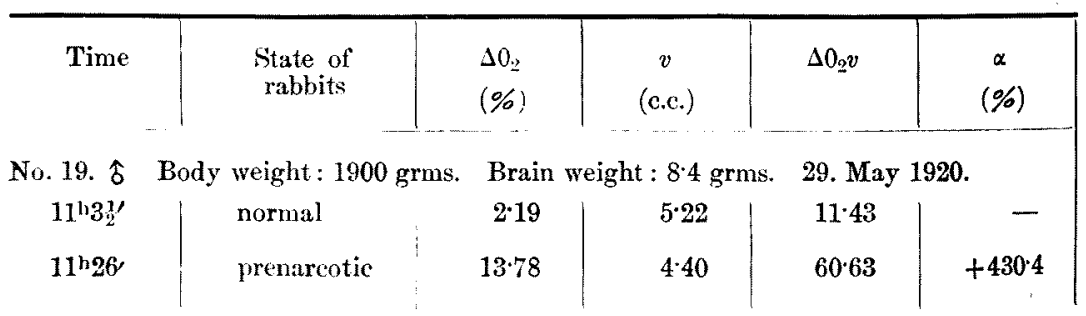


accelerated and, though weak, attained the normal number or more. When paralysis was completed, the respiration was very deep. The blood pressure ascended at first, then progressively descended as the corneal reflex disappeared and the pupils dilated. Some rabbits snored at the narcotic stage. On the withdrawal of administration, the blood pressure rose again, the pupils became normally large, the corneal reflex reappeared, the respiration and the cardiac beat were restored to normal conditions.

It is well known that chloroform affects the blood pressure and the function of the heart more markedly than ether; under chloroform the narcotic stage comes on earlier. But no comparative studies on the effect of these anaesthetics upon the cerebral gas metabolism have yet been published. In the following tables (Tables III-IV) the results of my experiments on the gaseous exchange in the chloroform narcosis are briefly summarized.

\section{Chloroform Narcosis.}

III, A.

\begin{tabular}{|c|c|c|c|c|}
\hline $\begin{array}{l}\text { Change in } v \\
\quad(\%)\end{array}$ & $\begin{array}{c}\text { Blood } \\
\text { pressure } \\
(\mathrm{mm} . \mathrm{Hg})\end{array}$ & $\underbrace{\text { Pulse }}_{p e}$ & $\frac{\text { Respiration }}{5^{\prime \prime}}$ & Remarks \\
\hline - & 112 & 17 & 12 & At $11^{\mathrm{b}} 44^{\prime}$ pulse 20 , respir. 10 \\
\hline+55.9 & 96 & 23 & 8 & $\begin{array}{l}\text { inhaled. Pupils large. Corneal } \\
\text { reflex positive. The animal quiet. }\end{array}$ \\
\hline-55.9 & 78 & 24 & $\begin{array}{c}8 \\
\text { (deep) }\end{array}$ & $\begin{array}{l}\text { At } 12^{\mathrm{h}} 16^{\prime} \text { pulse } 20 \text {, respir. } 8 \text {. } \\
\text { At } 12^{\mathrm{h}} 17^{\prime}-12^{\mathrm{h}} 27^{\prime} \mathrm{I}^{\prime} 3 \text { c.c. chloroform } \\
\text { inhaled. Corneal reflex dis- } \\
\text { appeared. }\end{array}$ \\
\hline$+2 \overline{4}$ & $\begin{array}{l}124 \\
124\end{array}$ & $\begin{array}{c}20 \\
10 \\
\text { (irregular) }\end{array}$ & $\frac{9}{5}$ & $\begin{array}{l}\text { At } 10^{\mathrm{h}} 33^{\prime}-10^{\mathrm{h}} 42^{\prime} 2 \text { c.c. chloroform } \\
\text { inhaled. Pupils normal. Corneal } \\
\text { reflex positive. The rabbit excited. }\end{array}$ \\
\hline
\end{tabular}

III, B.

\begin{tabular}{|c|c|c|c|c|}
\hline $\begin{array}{c}\text { Change in } v \\
(\%)\end{array}$ & $\begin{array}{c}\text { Blood } \\
\text { pressure } \\
(\mathrm{mm} . \mathrm{Hg})\end{array}$ & $\underbrace{\text { Pulse }}_{p e}$ & $\overbrace{5^{\prime \prime}}^{\text {Respiration }}$ & Remarks \\
\hline $\begin{array}{r}- \\
-157\end{array}$ & $\begin{array}{l}106 \\
140\end{array}$ & $\begin{array}{c}24 \\
\text { (weak) }\end{array}$ & $\begin{array}{c}13 \\
\text { (oo weak } \\
\text { to count) }\end{array}$ & $\begin{array}{l}\text { At } 11^{\mathrm{h}} 25^{\prime}-11^{\mathrm{h}} 28 \mathrm{y}^{\prime} \\
\text { form inhaled. } \\
\text { forc. chloro- } \\
\text { Corneal reflex positive. The } \\
\text { animal struggling. }\end{array}$ \\
\hline
\end{tabular}


Table

\begin{tabular}{|c|c|c|c|c|c|}
\hline Time & $\begin{array}{c}\text { State of } \\
\text { rabbits }\end{array}$ & $\begin{array}{c}\Delta 0_{2} \\
(\%)\end{array}$ & $\begin{array}{c}v \\
\text { (c.c.) }\end{array}$ & $\Delta 0_{2} v$ & $\begin{array}{c}\alpha \\
(\%)\end{array}$ \\
\hline
\end{tabular}

No. 22. \& Body weight: $1900 \mathrm{grms}$. Brain weight: 9.0 grms. 4. June 1920.

\begin{tabular}{|c|c|c|c|c|c|}
\hline $10^{\mathrm{h}} 7^{\prime}$ & normal & $7 \cdot 78$ & $5 \cdot 61$ & 4365 & - \\
\hline $10^{\text {h } 27^{\prime}}$ & prenarcotic & $4 \cdot 45$ & 6.86 & 3053 & $-30 \cdot 1$ \\
\hline $10^{\mathrm{b}} 53^{\prime}$ & $"$ & $7 \cdot 82$ & 6.49 & 5075 & $+16 \cdot 3$ \\
\hline $11^{\mathrm{h}} 13_{2}^{\prime \prime}$ & normal & $11 \cdot 26$ & 1.90 & 2139 & - \\
\hline
\end{tabular}

Narcotic Stage of

Table

\begin{tabular}{|c|c|c|c|c|c|}
\hline Time & $\begin{array}{c}\text { State of } \\
\text { rabbits }\end{array}$ & $\begin{array}{c}\Delta 0_{2} \\
(\%)\end{array}$ & $\begin{array}{c}v \\
\text { c.c. })\end{array}$ & $\Delta 0_{2} v$ & $\begin{array}{c}\alpha \\
(\%)\end{array}$ \\
\hline
\end{tabular}

To. 2. ㅇ Body weight: 1680 grms. Brain weight : 69 grms. 16. April 1920 .

\begin{tabular}{|c|c|c|c|c|c|}
\hline $\begin{array}{l}3^{\mathrm{h}} 12^{\prime} \\
3^{\mathrm{h}} 28^{\prime}\end{array}$ & $\begin{array}{l}\text { normal } \\
\text { narcotic }\end{array}$ & $\begin{array}{l}2 \cdot 89 \\
2 \cdot 59\end{array}$ & $\begin{array}{l}0.92 \\
0.99\end{array}$ & $\begin{array}{l}266 \\
256\end{array}$ & $-\overline{38}$ \\
\hline
\end{tabular}

No. 6. \& Body weight: 1940 grms. Brain weight: 81 grms. 1. May 1920 .

\begin{tabular}{|c|c|c|c|c|c|}
\hline $\begin{array}{l}4^{\mathrm{h}} 18^{\prime} \\
4^{\mathrm{h}} 38^{\prime}\end{array}$ & $\begin{array}{l}\text { normal } \\
\text { narcotic }\end{array}$ & $\begin{array}{l}6 \cdot 12 \\
1.79\end{array}$ & $\begin{array}{r}9 \cdot 76 \\
13 \cdot 91\end{array}$ & $\begin{array}{l}59 \cdot 73 \\
24 \cdot 90\end{array}$ & $-\overline{58 \cdot 3}$ \\
\hline $4^{1158^{\prime}}$ & normal & $9 \cdot 30$ & $6 \cdot 27$ & $58 \cdot 31$ & - \\
\hline 14. $\hat{\circ}$ & weight: & 19. M & & & \\
\hline $\begin{array}{l}3^{\mathrm{h}} 21^{\prime} \\
3^{\mathrm{h}} 45^{\prime}\end{array}$ & $\begin{array}{l}\text { normal } \\
\text { narcotic }\end{array}$ & $\begin{array}{r}10.45 \\
6.52\end{array}$ & $\begin{array}{l}3.93 \\
5 \cdot 11\end{array}$ & $\begin{array}{l}41 \cdot 07 \\
33 \cdot 32\end{array}$ & $-\overline{18 \cdot 9}$ \\
\hline
\end{tabular}

No. 21. \& Body weight: 1890 grms. Brain weight: 8.4 grms. 31. May 1920 .

\begin{tabular}{|c|c|c|c|c|c|}
\hline $9^{\mathrm{h}} 55^{\prime}$ & normal & $11 \cdot 81$ & 393 & $46 \cdot 41$ & \\
\hline $10^{\mathrm{h}} 16^{\prime}$ & narcotic & $8 \cdot 41$ & $4 \cdot 62$ & $38 \cdot 85$ & $-17 \cdot 6$ \\
\hline $10^{\mathrm{h}} 40^{\prime}$ & , & 6.90 & $4 \cdot 44$ & $30 \cdot 64$ & -337 \\
\hline $11^{\mathrm{h}} 40^{\prime}$ & normal & $13 \cdot 97$ & $2 \cdot 14$ & $39 \cdot 90$ & - \\
\hline
\end{tabular}


III, c.

\begin{tabular}{|c|c|c|c|c|}
\hline $\begin{array}{c}\text { Change in } v \\
(\%)\end{array}$ & $\begin{array}{c}\text { Blood } \\
\text { pressnre } \\
(\mathrm{mm} . \mathrm{Hg})\end{array}$ & $\underbrace{\text { Pulse }}_{\text {per }}$ & $\frac{\text { Respiration }}{5^{\prime \prime}}$ & Remarks \\
\hline - & 96 & 20 & 10 & $\begin{array}{l}\text { At } 10^{\mathrm{h}} 23^{\prime}-10^{\mathrm{h}} 30^{\prime} 2 \text { c.c. chloroform } \\
\text { inhaled. }\end{array}$ \\
\hline & 118 & $\begin{array}{c}10 \\
\text { (ir regular) }\end{array}$ & 4 & $\begin{array}{l}\text { Pupils normal. Corneal reflex posi- } \\
\text { tive. The rabbit quiet. }\end{array}$ \\
\hline+136 & 70 & 20 & 4 & $\begin{array}{l}\text { At } 10^{1} 48^{\prime} \text { pulse } 22, \text { respir. } 5 \text {. } \\
\text { At } 10^{\mathrm{b}} 47^{\prime}-10^{\mathrm{b}} 55^{\prime} 2 \text { c.c. ehloroform } \\
\text { inhaled. Pupils larger. Corneal } \\
\text { reflex positive. }\end{array}$ \\
\hline - & 78 & 20 & 5 & \\
\hline
\end{tabular}

Chloroform Narcosis.

IV, A.

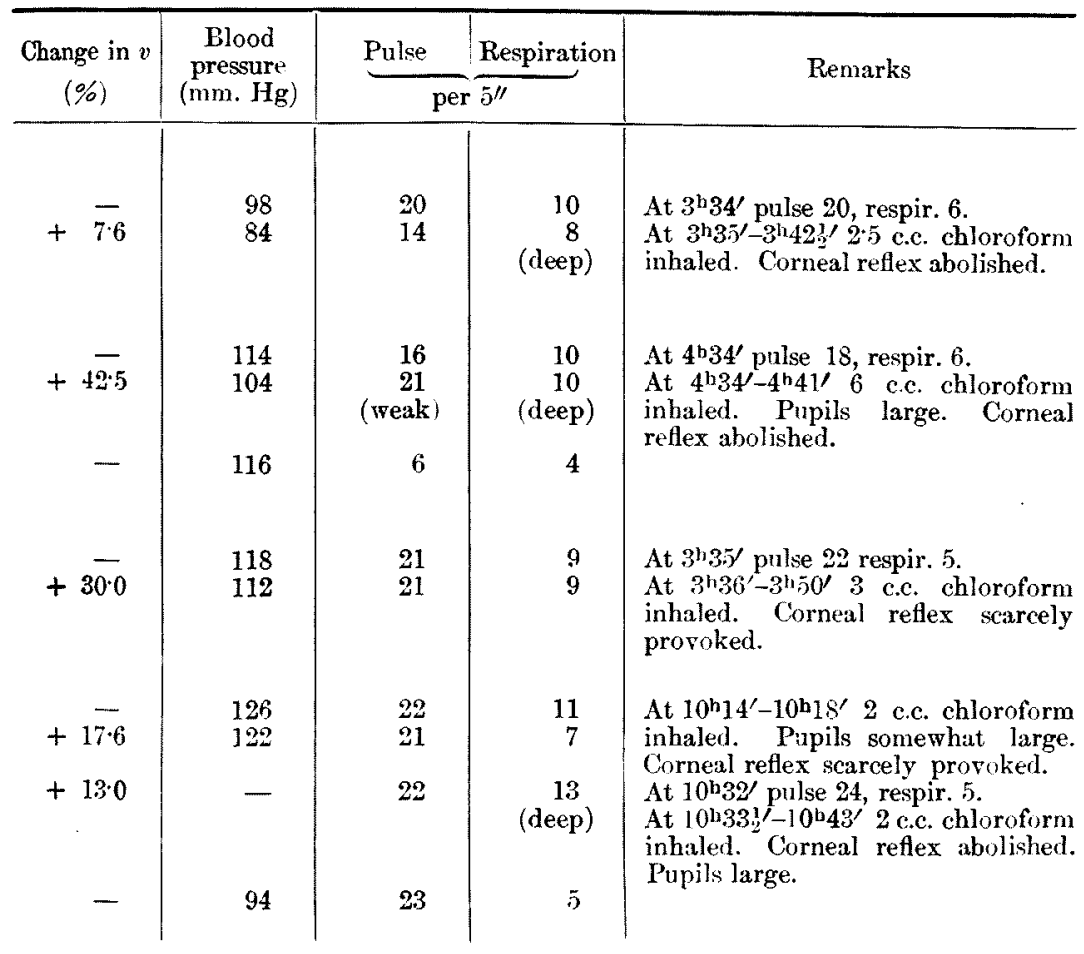


TABLE

\begin{tabular}{c|c|c|c|c|c|}
\hline Time & $\begin{array}{c}\text { State of } \\
\text { rabbits }\end{array}$ & $\begin{array}{c}\Delta 0_{2} \\
(\%)\end{array}$ & $\begin{array}{c}v \\
\text { (c.c.) }\end{array}$ & $\Delta 0_{2} v$ & $\begin{array}{c}\alpha \\
(\%)\end{array}$ \\
\hline
\end{tabular}

No. 8. $\hat{\delta}$ Body weight: 1900 grms. Brain weight: $8 \cdot 9$ grms. 8. May 1920 .

\begin{tabular}{|c|c|c|c|c|c|}
\hline $\begin{array}{c}9^{\mathrm{b}} 50^{\prime} \\
10^{\mathrm{b}} 21^{\prime}\end{array}$ & $\begin{array}{l}\text { normal } \\
\text { narcotic }\end{array}$ & $\begin{array}{l}7 \cdot 78 \\
6 \cdot 82\end{array}$ & $\begin{array}{l}3 \cdot 64 \\
267\end{array}$ & $\begin{array}{l}28 \cdot 32 \\
18 \cdot 21\end{array}$ & $-\overline{35 \cdot 5}$ \\
\hline $10^{\mathrm{b}} 45^{\prime \prime}$ & nornaal & $12 \cdot 45$ & 209 & 26.02 & \\
\hline
\end{tabular}

No. 20. 우 Body weight: 1540 grms. Prain weight: 8.6 grms. 30. May 1920 .

\begin{tabular}{l|l|l|l|l|r|}
$10^{\mathrm{h}} 54^{\prime}$ & normal & $9 \cdot 78$ & $8 \cdot 21$ & $80 \cdot 29$ & - \\
$11^{\mathrm{h}} 25^{\prime}$ & narcotic & $4 \cdot 59$ & $7 \cdot 55$ & 34.65 & $-56 \cdot 6$ \\
$11^{\mathrm{h}} 56 \mathrm{y}^{\prime}$ & normal & $7 \cdot 26$ & $3 \cdot 06$ & $22 \cdot 22$ & -
\end{tabular}

TABLE

\begin{tabular}{c|c|c|c|c|c}
\hline Time & $\begin{array}{c}\text { State of } \\
\text { rabbits }\end{array}$ & $\begin{array}{c}\Delta 0_{2} \\
(\%)\end{array}$ & $\begin{array}{c}v \\
\text { (c.c.) }\end{array}$ & $\Delta 0_{2} v$ & $\begin{array}{c}\alpha \\
(\%)\end{array}$ \\
\hline
\end{tabular}

No.9. $\hat{\delta}$ Body weight: 1800 grms. Brain weight: 8.0 grms. 12. May 1920 .

\begin{tabular}{l|l|r|r|r|r}
$3^{\mathrm{b}} 36_{2}^{\frac{1}{2}}$ & normal & 5.93 & 5.01 & 29.71 & - \\
$3^{\mathrm{h}} 55^{\prime}$ & narcotic & 5.56 & 2.50 & 13.90 & -53.2 \\
& & & & \\
$4^{\mathrm{h}} 22^{\prime}$ & normal & 13.75 & 1.87 & 25.71 & -
\end{tabular}

TABLE

\begin{tabular}{c|c|c|c|c|c|}
\hline Time & $\begin{array}{c}\text { State of } \\
\text { rabbits }\end{array}$ & $\begin{array}{c}\Delta 0_{2} \\
(\%)\end{array}$ & $\begin{array}{c}v \\
\text { (c.c. })\end{array}$ & $\Delta 0_{2} v$ & $\begin{array}{c}\alpha \\
(\%)\end{array}$ \\
\hline
\end{tabular}

No.16. 우 Body weight: 1960 grms. Brain weight: 944 grms. 22. May 1920 .

\begin{tabular}{|c|c|c|c|c|c|}
\hline $\begin{array}{l}2^{\mathrm{h}} 42^{\prime} \\
3^{\mathrm{h}} 3 \frac{1}{2}^{\prime}\end{array}$ & $\begin{array}{l}\text { normal } \\
\text { narcotic }\end{array}$ & $\begin{array}{l}6.85 \\
7 \cdot 92\end{array}$ & $\begin{array}{l}9.23 \\
6.08\end{array}$ & $\begin{array}{l}63 \cdot 23 \\
48 \cdot 15\end{array}$ & $-\overline{23.8}$ \\
\hline $3 \mathbf{b} 322^{\prime}$ & $"$ & $7 \cdot 41$ & $5 \cdot 65$ & 41.87 & -338 \\
\hline $4^{\mathrm{L}} 30^{\prime}$ & normal & $12: 30$ & $3 \cdot 24$ & $39 \cdot 85$ & \\
\hline
\end{tabular}

No. 17. \& Body weight; 2050 grms. Brain weight: 8.3 grms. 26. May 1920 .

\begin{tabular}{l|l|l|l|l|l}
$10^{\mathrm{b}} 30^{\prime}$ & normal & 6.56 & 0.81 & 5.31 & - \\
$11^{\mathrm{h}} 3^{\prime}$ & narcotic & 7.48 & 0.41 & 3.07 & -42.2
\end{tabular}


IV, B-I.

\begin{tabular}{|c|c|c|c|c|}
\hline $\begin{array}{c}\text { Change in } v \\
(\%)\end{array}$ & $\begin{array}{c}\text { Blood } \\
\text { pressure } \\
(\mathrm{mm} . \mathrm{Hg})\end{array}$ & $\underbrace{\text { Pulse }}_{\text {per }}$ & $\frac{\text { Respiration }}{5^{\prime \prime}}$ & Remarks \\
\hline$-\overline{26 \cdot 6}$ & $\begin{array}{l}110 \\
114 \\
110\end{array}$ & $\begin{array}{c}20 \\
\text { scarcely com- } \\
\text { putable (weak) } \\
18\end{array}$ & $\begin{array}{l}10 \\
12 \\
5\end{array}$ & $\begin{array}{l}\text { At } 10^{\mathrm{h}} 16^{\prime} \text { pulse } 18 \text {, respir. } 6 \text {. } \\
\text { At } 10^{\mathrm{h}} 17^{\prime}-10^{\mathrm{h}} 24^{\prime} 25 \text { c.c. chloroform } \\
\text { inhaled. Pupils large. Corneal } \\
\text { reflex abolished. }\end{array}$ \\
\hline $\begin{array}{r}-\overline{8 \cdot 0} \\
-\end{array}$ & $\begin{array}{r}102 \\
66 \\
96\end{array}$ & $\begin{array}{r}18 \\
18 \\
15 \\
\text { (irregular) }\end{array}$ & $\begin{array}{l}6 \\
7 \\
5\end{array}$ & $\begin{array}{l}\text { At } 11^{\mathrm{h}} 19-11^{\mathrm{h}} 292 \text { c.c. chloroform } \\
\text { inhaled. Pupils large. Corneal } \\
\text { reflex abolished. }\end{array}$ \\
\hline
\end{tabular}

IV, $\mathbf{B}-\mathbf{2}$.

\begin{tabular}{|c|c|c|c|c|}
\hline $\begin{array}{c}\text { Change in } v \\
(\%)\end{array}$ & $\begin{array}{c}\text { Blood } \\
\text { pressure } \\
\text { (mm. Hg) }\end{array}$ & $\underbrace{\text { Pulse }}_{\text {per }}$ & $\frac{\text { Respiration }}{5^{\prime \prime}}$ & Remarks \\
\hline $\begin{array}{r}-50 \cdot 1 \\
-\end{array}$ & $\begin{array}{r}118 \\
62 \\
96\end{array}$ & $\left|\begin{array}{cc}20 \\
\text { scarcely } & \text { com- } \\
\text { putable } & \text { (weak) } \\
18\end{array}\right|$ & $\begin{array}{c}12 \\
12 \\
(\text { deep })\end{array}$ & $\begin{array}{l}\text { At } 3^{\mathrm{b}} 5 \mathrm{1}^{\prime} \text { pulse } 20 \text {, respir. } 8 \text {. } \\
\text { At } 3^{\mathbf{b}} 52^{\prime}-3^{\mathrm{h}} 55^{\prime} 2 \text { c.c. chloroform } \\
\text { inhaled. Pupils large. }\end{array}$ \\
\hline
\end{tabular}

IV, $\mathbf{B - 3 .}$

\begin{tabular}{|c|c|c|c|c|}
\hline $\begin{array}{c}\text { Change in } v \\
(\%)\end{array}$ & $\begin{array}{l}\text { Blood } \\
\text { pressure } \\
\text { (mm. Hg) }\end{array}$ & Pulse & $\frac{\text { Respiration }}{5^{\prime \prime}}$ & Remarks \\
\hline - & 118 & 19 & 10 & At $2 \mathbf{b}^{\mathbf{b}} \overline{4}^{\prime}$ oulse \\
\hline$-34 \cdot 1$ & 108 & 21 & 9 & $\begin{array}{l}\text { At } 2^{\text {b }} 55^{\prime}-3^{h} 62^{\prime} 4 \text { c.c. chloroform in- } \\
\text { haled. Pupils large. Corneal } \\
\text { reflex abolished. }\end{array}$ \\
\hline-38.8 & 80 & 21 & 6 & $\begin{array}{l}\text { At } 3^{\text {h }} 24^{\prime} \text { pulse } 20 \text {, respir. } 5 \text {. } \\
\text { At } 3^{\text {h } 25^{\prime}}-3^{\text {h } 39^{\prime}} 3 \text { c.c. chloroform } \\
\text { inhaled. Pupils large. Corneal } \\
\text { reflex abolished. }\end{array}$ \\
\hline- & 84 & 19 & 5 & \\
\hline - & 94 & 24 & 12 & $\begin{array}{l}\text { At } 10^{\mathrm{h}} 59^{\prime} \text { pulse } 20 \text {, respir } 9 . \\
\text { At } 11^{\mathrm{h}}-11^{1} 15^{\prime} 3 \text { chloroform in }\end{array}$ \\
\hline$-49 \cdot 4$ & 64 & 20 & 8 & $\begin{array}{l}\text { haled. Pupils large. Corneal } \\
\text { reflex abolished. }\end{array}$ \\
\hline
\end{tabular}




\begin{tabular}{c|c|c|c|c|c|}
\hline Time & $\begin{array}{c}\text { State of } \\
\text { rabbits }\end{array}$ & $\begin{array}{c}\Delta 0_{2} \\
(\%)\end{array}$ & $\begin{array}{c}v \\
\text { (c.c:) }\end{array}$ & $\Delta 0_{2} v$ & $\begin{array}{c}\alpha \\
\%)\end{array}$ \\
\hline
\end{tabular}

No. 10. \& Body weight: 1650 grms.

\begin{tabular}{l|l}
$3^{\mathbf{l}} 24^{\prime}$ & normal \\
$3^{\mathbf{b}} 46^{\prime}$ & narcotic
\end{tabular}

Brain weight : $7 \cdot 8$ grms.
3.04
\begin{tabular}{l|c|c|c|} 
& 13. & May 1920 . \\
6.15 & 0.19 & 3.62 & - \\
& 0.59 & 3.63 & +0.3
\end{tabular}

In the prenarcotic stage of chloroform narcosis both the oxygen consumption and the blood flow of the brain showed usually an increase. Sometimes (Exp. 22) the oxygen consumption increased parallel to the increase in the blood flow, as observed in the prenarcotic stage with ether, and sometimes (Exp. 19) it rose with slight change in the blood flow, but more frequently (Exp. $15 \& 18$ ), the rate of increase in the oxygen consumption was less than that in the blood flow; especially in the case of Exp. 22 shown in the Table III, c, the oxygen consumption decreased, whilst the blood flow was increased and the corneal reflex still reacted normally. It follows from these observations that the excitability of the central nervous system in this stage of chloroform narcosis may be considered to be less than that of ether. In reality, as we observed the condition of the rabbits, the excitement by chloroform was far weaker and far shorter than that by ether. Consequently we infer that the rise of gascous exchange in the prenarcotic stage of chloroform narcosis isprobably caused by the marked increase in the blood flow rather than by the excitement of the brain itself.

In Exp. 19 the rabbit was inteusively excited and struggling, so that the oxygen consumption in the brain was markedly accelerated though the blool flow was rather reduced. Not only with ether but with chloroform also, the gaseous exchange rose sometimes abnormally for a moment in the earliest stage on account of the excitement of the animals. In Exp. 4 of ether (Table I) and Exp. 18 and 19 of chloroform (Table IJI, A and B) the blood was taken for measurement during the most marked excitement, one minute after the drug began to drop on the mask.

In the narcotic stage of chloroform narcosis, the oxygen consumption always decreased. The blood flow was frequently accelerated, but sometimes retarded. Out of 11 experiments, Exp. 2, 6, $14 \& 21$ at the narcotic stage showed a slight fall of the arterial blood pressure and an 
IV, $\mathrm{c}$

\begin{tabular}{|c|c|c|c|c|}
\hline $\begin{array}{c}\text { Change in } v \\
(\%)\end{array}$ & $\begin{array}{c}\text { Blood } \\
\text { pressure } \\
\text { (mm. Hg) }\end{array}$ & Pulse & $\frac{\text { Respiration }}{5^{\prime \prime}}$ & Remarks \\
\hline $\begin{array}{r}- \\
-50 \cdot 4\end{array}$ & $\begin{array}{l}94 \\
92\end{array}$ & $\begin{array}{l}20 \\
20\end{array}$ & $\begin{array}{l}4 \\
8\end{array}$ & 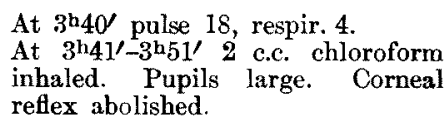 \\
\hline
\end{tabular}

increased blood flow, whereas the oxygen consumption on the contrary decreased, thus indicating a pronounced depressant action of chloroform on the brain. In the experiments given in 'lable IV, B it was found that there was a decrease in the blood flow in all cases while the decrease in the oxygen consumption was not always paralled to it. The results may be classified into three groups, that is, group $\mathrm{A}$ in which the decrease in the oxygen consumption was greater than that in the blood flow, group B in which the change in the oxygen consumption went paralled to that in the blood flow and group $\mathrm{C}$ in which the reduction in the oxygen intake was less than that in the blood flow. No change in the oxygen consumption was observed in Exp. 10, in which the blood was collected in the relatively early stage with no descent of the blood pressure.

In short, the disturbance of the oxygen consumption in chloroform narcosis may be attributed to the direct depressant effects of chloroform on the central nervous system, or to its inhibitory action on the oxidation in the brain, but not exclusively to the change in the blood flow through the brain. In the stage of reconvalescence, the oxygen consumption approached to its normal height, but, notwithstanding the blood pressure also being restored, the rate of the blood flow decreased still further (Exp. 6, 8, 9, 16, 20\&21); a striking feature of the action of chloroform, entirely different from that of ether. This fact, that in the reconvalescent stage of chloroform narcosis, in spite of the blood flow descending lower, the oxygen consumption regains its nearly normal value, suggests that recovery of the oxidative process and the activity of the brain from chloroform narcosis are comparatively prompt and perfect.

In Exp.16, $20 \& 21$, the reason why the rate of the oxygen consumption was not restored is attributable to the blood flow decreasing too low, probably not to the continued depression of the nervous cells. A 
similar result was also observed in the reconvalescent stage of the ether narcosis (Exp. 16, 20 \& 29 Table II, C).

Roughly taken, the depressive effect of chloroform on the cerebral function is three times or three times and a half as much as that of ether. In all the experiments the amount of chloroform used was about one third that of ether, the rate of dropping it on the mask was the same as with ether and the average rate of decrease in the oxygen consumption in 10 experiments at the narcotic stage of chlorform narcosis was $38 \%$ $(3 \cdot 8-58 \cdot 3 \%)$; somewhat less than that in the ether narcosis. The oxygen consumption $\Delta 0_{2} v$ was more frequently and extensively influenced by the change in $v$ than in $\Delta 0_{2}$. In chloroform narcosis, though the narcotic power of chloroform is great, the value of $v$, as mentioned above, increased in many cases in the narcotic stage. Therefore, however small $\mathrm{SO}_{2}$ may be, the rate of the decrease in $\Delta \mathrm{O}_{2} v$ is comparatively small because of the increase in $v$. In the case of ether, on the contrary, $v$ together with $\Delta \mathrm{O}_{2}$ decreased, and $\Delta \mathrm{O}_{2} v$ underwent comparatively a great change. So, in the chloroform narcosis the rate of the decrease in the oxygen consumption is less than in the ether narcosis, in spite of its powerful depressive effect.

Thus, it has been proved that the disturbance of the oxygen consumption shown in narcosis is modified indirectly more or less by the change in the blood flow.

Concerning the action of chloroform on the cerebral vessels, Gärtuer and Wagner maintained an active dilation, Roy and Sherrington ${ }^{2}$ showed on the contrary contraction of the vessels, while Bayliss and $\mathrm{Hill}^{3)}$ believed that in dogs the administration of chloroform produced a fall of arterial pressure with a consequent rise in the general venous pressure, and owing to the greater effect of the arterial fall, the cerebral venous pressure also fell, but in the later stages of chloroform poisoning, there was a rapid rise in the cerebral venous pressure passively following the now greatly increased pressure in the right auricle, due to the failure of the heart. Pick ${ }^{4}$ noticed in experiment on dogs under chloroform an increase in the blood flow through the external jugular vein combined with the descent of arterial blood pressure, whereby the stimulation of the vagus produced a reduction

1) Gärtner and Wagner, Wien. med. Wochenschr., 1887, 602.

2) Roy and Sherrington, l. c.

3) Bayliss and $\mathrm{Hill}$, l.c.

4) Pick, l. c. 
of the blood flow and arterial blood pressure and assumed the entirely active dilation of the cerebral vessels.

In all of my experiments in the prenarcotic stage an increase in the blood flow through the brain could be demonstrated, while the arterial blood pressure underwent no constant variation; in one case (Exp. 15) it descended somewhat, in another case (Exp. 18) no change was produced. In Exp. 22 the blood flow increased, not only when the blood pressure ascended, but also when it descended. From these facts it may be assumed that the dilation of the cerebral vessels occurs without any relation to the change in the arterial blood pressure. In the narcotic stage, especially at its beginning, the arterial blood pressure sometimes slightly fell, and the blood flow through the brain was augmented (Exp. 2, 6, $14 \& 21$ ), but when the former descended further, the latter decreased (Exp. 9, 15, 16, $17 \& 20$ ); in other cases (Exp. $8 \& 10$ ) the blood flow fell without the descent of the blood pressure. It is of particular interest to note that during the stage of reconvalescence of the narcosis, though the blood pressure again ascended and the action of the heart and the respiration were restored, the blood flow still further decreased, and in some cases the venous blood scarcely flowed out for a period of even 30 minutes after awakening. This probably indicates an active contraction of the blood vessels. In the narcosis by chloroform as well as in that by ether, there was a primary dilation of the cerebral vessels, which was in the later stage followed by a noticeable contraction lasting for a long time. However, the decrease in the blood flow through the brain might be due in part to the dilation of the veins of the splanchnic region and the descent of arterial blood pressure.

The descent of the arterial blood pressure and the dilation of the veins of the splanchnic region caused by chloroform began far later and lasted longer than the dilation of the cerebral vessels, and after the arterial blood pressure was restored, there was a marked contraction of the cerebral vessels lasting for a long time; a fact which shows that the mechanism of the action of chloroform on the adominal vessels is different from that on the cerebral vessels.

That in Exp. 19 the blood flow decreased, though slightly, while the arterial blood pressure ascended and the rabbit showed a marked excitement may be due to the temporary arrest of the heart action and the respiration by the reflex stimulus.

The depressive action of chloroform both on the central nervous 
system and the circulation system was much more serious than that of ether; but a more striking feature of the chloroform narcosis was that, as illustrated above, the cerebral blood flow through the stage of reconvalescence of narcosis was more delayed. In the case of ether, the arterial blood pressure remained declined in the stage of reconvalescence while the once decreased blood flow through the brain showed a tendency to be restored. On the other hand, in the case of chloroform, though the blood pressure was restored, the blood flow decreased still more. Besides, though in both the cases of ether and chloroform, the period in which the change in the blood flow through the brain took place did not always agree with that in which the corneal reflex of the rabbit disappeared, during the chloroform narcosis, the blood flow through the brain was augmented for a long time, often even after the corneal reflex was abolished. This suggests that the constriction of the cerebral ves-

Effect of

TABLE

\begin{tabular}{c|c|c|c|c|c|}
\hline Time & $\begin{array}{l}\text { State of } \\
\text { rabbits }\end{array}$ & $\begin{array}{c}\Delta 0_{2} \\
(\%)\end{array}$ & $\begin{array}{c}v \\
(\text { c.c. })\end{array}$ & $\Delta c_{2} v$ & $\begin{array}{c}\alpha \\
(\%)\end{array}$ \\
\hline
\end{tabular}

No. 4. 우 Body weight : 2000 grms. Brain weight : 7.8 grms. 19. June 1920 .

\begin{tabular}{l|l|r|r}
$11^{\text {h }} 38^{\prime}$ & normal & 8.30 & 4.56 \\
$12^{\mathrm{h}} 26^{\prime}$ & under morphine & $7 \cdot 30$ & 4.32 \\
$12^{\mathrm{l}} 50^{\prime}$ & & 10.63 & 2.53
\end{tabular}

No.6. 우 Body weight: 2450 grms. 25. June 1920 .

$10^{1,27}$

$11^{\mathrm{h}} 13^{\prime}$

normal $\mid$

$5 \cdot 90$
$5 \cdot 30$
$1 \cdot 90$

$3 \cdot 13$
$2 \cdot 96$
$3 \cdot 04$

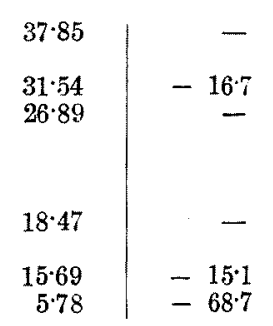

No. 8. 우 Body weight: 2600 grms. Brain weight: 8.5 grms. 26. June 1920 .
$4^{\mathrm{h}} 16_{2}^{\mathrm{y}}$
$5^{\mathrm{h}} 4{ }_{2}^{\prime \prime}$
normal
nnder morphine
$4 \cdot 89$
$5 \cdot 26$
$2 \cdot 82$
$16 \cdot 00$
$7 \cdot 62$
6.08
\begin{tabular}{l|r}
$45 \cdot 12$ & - \\
$37 \cdot 26$ & $-17 \cdot 4$ \\
$31 \cdot 98$ & $-29 \cdot 1$
\end{tabular}

No. 11. 우 Body weight: 1800 grms. Brain weight: 8.8 grms. 3. July 1920 .

\begin{tabular}{|c|c|c|c|c|c|}
\hline $4^{\mathrm{b}} 47^{\prime}$ & normal & $9 \cdot 37$ & $4 \cdot 53$ & $42 \cdot 45$ & - \\
\hline $5^{\mathrm{h}} \mathbf{4}^{\prime}$ & " & $9 \cdot 78$ & 4.29 & $41 \cdot 96$ & $96 \cdot 8$ \\
\hline $5^{\mathrm{l}} 37^{\prime}$ & under morphine & $8 \cdot 19$ & 375 & $30 \cdot 71$ & -268 \\
\hline $5^{\mathrm{h}} 53^{\prime}$ & & $9 \cdot 97$ & $4 \cdot 14$ & $41 \cdot 28$ & -16 \\
\hline
\end{tabular}


sels shown in the later stage of narcosis occurred far later and lasted far longer in the case of chloroform than in the case of ether.

\section{MoRphine.}

A $2 \%$ solution of morphium hydrochloricum in Ringer was injected hypodermically into the rabbit by $1-3$ c.c. per kilo of body weight and the blood gas was analyzed once before and twice after the injection.

One of the most marked effects of morphine was the decrease of the respiratory rate : viz. once or twice every ten seconds. The arterial blood pressure did not change considerably, but the heart rate decreased, and became irregular when a large dosis was injected. The size of the pupils did not change and corneal reflex was always positive.

\section{Morphine.}

$\mathrm{V}, \mathrm{A}$.

\begin{tabular}{|c|c|c|c|c|}
\hline $\begin{array}{l}\text { Change in } v \\
(\%)\end{array}$ & $\begin{array}{c}\text { Blood } \\
\text { pressure } \\
\text { (mm. Hg) }\end{array}$ & $\underbrace{\text { Pulse }}_{p}$ & $\frac{\text { Respiration }}{5^{\prime \prime}}$ & Remarks \\
\hline - & 112 & 23 & 13 & At $12^{\mathrm{b} 2} / 0.04 \mathrm{grm}$. morphine in- \\
\hline$-5 \cdot 3$ & $\begin{array}{l}112 \\
102\end{array}$ & $\begin{array}{l}16 \\
20\end{array}$ & $\begin{array}{l}3 \\
3\end{array}$ & At $12^{\mathrm{h}} 16^{\prime} 0.04 \mathrm{grm}$. again injected. \\
\hline- & 100 & 18 & 13 & At $10^{\mathrm{h}} 38^{\prime} 0.05 \mathrm{grm}$. morphine in- \\
\hline $\begin{array}{l}-\quad 3 \cdot 2 \\
-\quad 2 \cdot 9\end{array}$ & $\begin{array}{l}100 \\
104\end{array}$ & $\begin{array}{l}18 \\
13\end{array}$ & 13 & $\begin{array}{l}\text { At } 11^{\text {b } 1^{\prime}} 0.024 \text { grm. morphine in- } \\
\text { jected. }\end{array}$ \\
\hline- & 120 & 24 & 16 & At $4^{\mathrm{h}} 42^{\prime} \quad 0.054$ grm. morphine in- \\
\hline $\begin{array}{l}-52 \cdot 4 \\
-62 \cdot 0\end{array}$ & $\begin{array}{l}106 \\
106\end{array}$ & $\begin{array}{l}20 \\
20\end{array}$ & $\begin{array}{l}3 \\
2\end{array}$ & $\begin{array}{l}\text { At } 4^{\text {h }} 53^{\prime} 0.027 \text { grm. morphine in- } \\
\text { jected. }\end{array}$ \\
\hline - & 124 & 20 & 14 & \\
\hline$-\overline{126}$ & $\begin{array}{l}124 \\
110\end{array}$ & $\begin{array}{l}20 \\
20\end{array}$ & $\begin{array}{c}14 \\
3 \\
10\end{array}$ & At $5^{\mathrm{b}} 15^{\prime} 0.09 \mathrm{grm}$. morphine in- \\
\hline$-3 \cdot 5$ & 122 & 20 & $\begin{array}{c}5 \\
5 \\
\left(\text { per } 10^{\prime \prime}\right)\end{array}$ & \\
\hline
\end{tabular}


TABle

\begin{tabular}{|c|c|c|c|c|c|}
\hline Time & $\begin{array}{l}\text { State of } \\
\text { rabbits }\end{array}$ & $\begin{array}{l}\Delta 0_{2} \\
(\%)\end{array}$ & $\begin{array}{c}v \\
\text { (c.c.) }\end{array}$ & $\Delta 0_{2} v$ & $\begin{array}{c}\alpha \\
(\%)\end{array}$ \\
\hline 5. 5. 우 & ight: $2560 \mathrm{~g}$ & \multicolumn{2}{|c|}{ 23. June 1920.} & & \\
\hline $\begin{array}{l}10^{\mathrm{b}} 45^{\prime} \\
11^{\mathrm{h}} 15^{\prime} \\
11^{\mathrm{h}} 39^{\prime}\end{array}$ & $\begin{array}{l}\text { normal } \\
\text { under morphine }\end{array}$ & $\begin{array}{l}7 \cdot 10 \\
5 \cdot 50 \\
7 \cdot 00\end{array}$ & $\begin{array}{l}0.98 \\
1.20 \\
0.74\end{array}$ & $\begin{array}{l}6.96 \\
6.60 \\
5 \cdot 18\end{array}$ & $\begin{array}{r}\overline{5.2} \\
-25.6\end{array}$ \\
\hline
\end{tabular}

No. 9. 5 Body weight: 1960 grms. Brain weight: 8.3 grms. 2. July 1920 .

\begin{tabular}{|c|c|c|c|c|c|}
\hline $\begin{array}{l}3 \mathrm{~b} 2^{\prime} \\
4^{\mathrm{b}} 6^{\prime}\end{array}$ & normal & $\begin{array}{l}2 \cdot 89 \\
2 \cdot 74\end{array}$ & 1.94 & $\begin{array}{l}5 \cdot 61 \\
5 \cdot 81\end{array}$ & $\begin{array}{r}\overline{3 \cdot 7} \\
+\quad 5\end{array}$ \\
\hline
\end{tabular}

No. 12. \& Body weight: 1820 grms. Brain weight: $8 * 4$ grms. 5. July 1920 .

\begin{tabular}{|c|c|c|c|c|c|}
\hline $10^{\mathrm{b}} 52^{\prime}$ & normal & $\begin{array}{r}7 \cdot 93 \\
10.45\end{array}$ & $2 \cdot 24$ & $17 \cdot 76$ & - \\
\hline $\begin{array}{l}11^{n} 16^{\prime} \\
14^{\prime}\end{array}$ & & 1045 & 203 & 2121 & \\
\hline $12^{\mathrm{h}} 6^{\prime}$ & under morpmine & 8.15 & 1.50 & 12.23 & -42.8 \\
\hline
\end{tabular}

TABLE

\begin{tabular}{c|c|c|c|c|c|}
\hline Time & $\begin{array}{c}\text { State of } \\
\text { rabbits }\end{array}$ & $\begin{array}{c}\Delta 0 \\
(\%)\end{array}$ & $\begin{array}{c}v \\
\text { (c.c.) }\end{array}$ & $\Delta 0_{2} v$ & $\begin{array}{c}\alpha \\
(\%)\end{array}$ \\
\hline
\end{tabular}

No. 10. 우 Body weight: 1950 grms. Brain weight: 8.7 grms. 3. July 1920 .

\begin{tabular}{|c|c|c|c|c|c|}
\hline $10^{\mathrm{b}} 37^{\prime}$ & normal & $6 \cdot 89$ & $2 \cdot 53$ & $17 \cdot 43$ & - \\
\hline $11^{\mathrm{b}} 5^{\prime}$ & under morphine & $6 \cdot 04$ & $6 \cdot 32$ & $38 \cdot 17$ & $+119 \cdot 0$ \\
\hline $11^{\mathrm{b}} 23^{\prime}$ & & $6 \cdot 41$ & $6 \cdot 67$ & 38.75 & 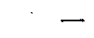 \\
\hline
\end{tabular}

No. 14. 우 Body weight: 2050 grms. Brain weight: 10.0 grms. 8. July 1920 .

\begin{tabular}{|c|c|c|c|c|c|}
\hline $\begin{array}{l}2^{10} 44^{\prime} \\
3^{\mathrm{h}} 36^{\prime}\end{array}$ & $\begin{array}{l}\text { normal } \\
\text { under morphine }\end{array}$ & $\begin{array}{r}9 \cdot 41 \\
11 \cdot 15\end{array}$ & $\begin{array}{l}2 \cdot 73 \\
3 \cdot 12\end{array}$ & $\begin{array}{l}25 \cdot 69 \\
3479\end{array}$ & +354 \\
\hline
\end{tabular}

As illustrated in the tables, the influence of morphine on the oxygen consumption of the brain was very slight. Alexander and Cserna $a^{1)}$ reported a decrease of $57 \cdot 2 \%$ in the dog, but in my experiments on rabbits it was not more than $13.6 \%$ on an average $(0.2-$ $26.8 \%$ ) in 20-25 minutes after the injection, sometimes nil. The change in the cerebral blood flow was not manifest either. In some cases the decrease in the oxygen consumption was accompanied by only a slight or no reduction of the rate of blood flow, in another cases it was less than that of the blood flow ('Table V, A). In the cases shown in

1) Alexander and Cserna, l.c. 
V, B.

\begin{tabular}{|c|c|c|c|c|}
\hline $\begin{array}{l}\text { Change in } v \\
(\%)\end{array}$ & $\begin{array}{c}\text { Blood } \\
\text { pressure } \\
(\mathrm{mm} . \mathrm{Hg})\end{array}$ & Pulse & $\frac{\text { Respiration }}{5^{\prime \prime}}$ & Remarks \\
\hline $\begin{array}{r}-\overline{-} \\
+\quad 22 \cdot 4 \\
-\quad 24.5\end{array}$ & $\begin{array}{l}116 \\
112 \\
110\end{array}$ & $\begin{array}{l}22 \\
17 \\
15\end{array}$ & $\begin{array}{r}12 \\
3 \\
3\end{array}$ & $\begin{array}{l}\text { At } 10^{\mathrm{h}} 55^{\prime} 0.052 \mathrm{grm} \text {. morphine in- } \\
\text { jected. }\end{array}$ \\
\hline$+\overline{9 \cdot 3}$ & $\begin{array}{l}120 \\
122\end{array}$ & $\begin{array}{l}24 \\
16\end{array}$ & $\begin{array}{c}16 \\
3 \\
\text { (per } 10^{\prime \prime} \text { ) }\end{array}$ & $\begin{array}{l}\text { At } 3^{\text {h }} 25^{\prime} \\
\text { jected. }\end{array}$ \\
\hline $\begin{array}{r}-\overline{ } \\
+31 \cdot 5 \\
-26.1\end{array}$ & $\begin{array}{r}110 \\
108 \\
100 \\
92\end{array}$ & $\begin{array}{l}22 \\
22 \\
22 \\
20\end{array}$ & $\begin{array}{r}10 \\
8 \\
8 \\
5\end{array}$ & $\begin{array}{l}\text { At } 11^{\mathrm{b}} 30^{\prime} 0.036 \mathrm{grm} \text {. morphine in- } \\
\text { travenously injected. }\end{array}$ \\
\hline
\end{tabular}

V, c.

\begin{tabular}{|c|c|c|c|c|}
\hline \multirow{2}{*}{$\begin{array}{l}\text { Change in } v \\
(\%)\end{array}$} & \multirow{2}{*}{$\begin{array}{c}\text { Blood } \\
\text { pressure } \\
\text { (mm.Hg) }\end{array}$} & Pulse & Respiration & \multirow[t]{2}{*}{ Remarks } \\
\hline & & \multicolumn{2}{|c|}{ per $5^{\prime \prime}$} & \\
\hline- & 138 & 18 & 9 & \\
\hline$+157 \cdot 7$ & 128 & $\begin{array}{c}9 \\
\text { (irregular) }\end{array}$ & & $\begin{array}{l}\text { At } 10^{\mathrm{h}} 45^{\prime} \\
\text { jected. }\end{array}$ \\
\hline- & 112 & $\begin{array}{c}17 \\
\text { (irregular } \\
\left.\text { per } 10^{\prime \prime}\right)\end{array}$ & $\left(\right.$ per $\left.10^{\prime \prime}\right)$ & \\
\hline$+\overline{142}$ & $\begin{array}{r}108 \\
98\end{array}$ & $\begin{array}{l}17 \\
11\end{array}$ & $\begin{array}{c}15 \\
5 \\
\text { (per 10') }\end{array}$ & $\begin{array}{l}\text { At } 3^{\text {h }} 20^{\prime} 0.08 \mathrm{grm} \text {. morphine intra- } \\
\text { venously injected. }\end{array}$ \\
\hline
\end{tabular}

Table V,B, the blood flow increased while the oxygen consumption did not change, but in the cases shown in Table V, o both the blood flow and the oxygen consumption increased. In rabbits the action of morphine on the brain and on the gaseous exchange was very insignificant and thereby the change in the oxygen consumption of the brain went frequently hand in hand with that in the blood flow.

The action of morphine on the cerebral circulation was also not remarkable, and the relation between the cerebral blood flow and the arterial blood pressure was not always constant; often the blood flow changed parallel with the blood pressure, thus in Exp. $8 \& 11$ they both 
decreased and in Exp. 4, 6 \& 9 they were unchanged. On the other hand in Exp. 5, 10, $12 \& 14$ the blood flow increased whilst the blood pressure descended, indicating a dilation of the cerebral vessels.

According to the studies of Gärtner and Wagner, Roy and Sherrington ${ }^{2)}$ and others, the effect of morphine on the cerebral circulation is trifling. Only $\mathrm{Sch}$ ïller ${ }^{1)}$ has described that with opium tincture the cerebral vessels first dilate, then contract. Frankfurther and $\mathrm{Hirsch} \mathrm{feld}^{2}$ observed in cats an initial increase of brain volume, followed by decrease, probably the former due to the active dilation of the cerebral vessels, but the latter due to the fall in the general blood pressure.

So far as concerns the relation between the doses of morphine and the change in the oxygen consumption and blood flow, I could ascertain no difference between the doses of morphine: 1, 1.5, 2, 2.5 and 3 c.c. of $2 \%$ solution per kilo of body weight. In Exp. 12 and 14, where morphine was administered intravenously, the blood pressure somewhat

Effect of

TABLE

\begin{tabular}{c|c|c|c|c|c|}
\hline Time & $\begin{array}{c}\text { State of } \\
\text { rabbits }\end{array}$ & $\begin{array}{c}\Delta 0_{2} \\
(\%)\end{array}$ & $\begin{array}{c}v \\
\text { (c.c.) }\end{array}$ & $\Delta 0_{2} v$ & $\begin{array}{c}\alpha \\
(\%)\end{array}$ \\
\hline
\end{tabular}

No. 1. ㅇ Body weight: 2040 grms. Brain weight: $9 \cdot 7$ grms. 10. July 1920 .

\begin{tabular}{l|l|r|r|r|r}
$11^{\mathrm{h}} y^{\prime}$ & normal & $10 \cdot 41$ & $3 \cdot 46$ & 36.02 & - \\
$11^{\mathrm{h}} 47^{\prime}$ & under pantopon & 9.82 & $2 \cdot 18$ & 21.41 & $-40 \cdot 6$ \\
$12^{\mathrm{h}} 14^{\prime}$ & & 12.41 & $1 \cdot 22$ & 15.14 & -
\end{tabular}

No. 4. $\hat{\delta}$ Body weight : 2050 grms. Brain weight 9.5 grms. 13. July 1920 .

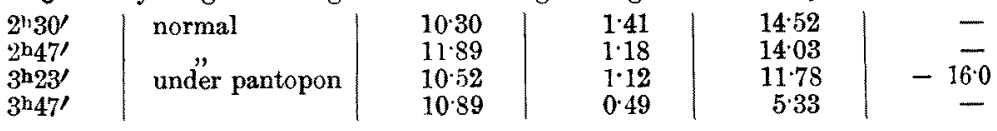

No. 5. \& Body weight: 1820 grms. Brain weight : 9.5 grms. 14. July 1920.

\begin{tabular}{|c|c|c|c|c|c|}
\hline $\begin{array}{l}11^{\mathrm{h}} 22^{\prime} \\
11^{\mathrm{h}} 55^{\prime} \\
12^{\mathrm{b}} 16^{\prime}\end{array}$ & $\begin{array}{l}\text { normal } \\
\text { under pantopon }\end{array}$ & $\begin{array}{l}9 \cdot 48 \\
6.60 \\
7 \cdot 57\end{array}$ & $\begin{array}{l}1.15 \\
0: 88\end{array}$ & $\begin{array}{r}10.90 \\
5.81\end{array}$ & \\
\hline
\end{tabular}

No. 8. $\delta$ Body weight: 1770 grms. Brain weight: $9 \cdot 9$ grms. 17. July 1920 .

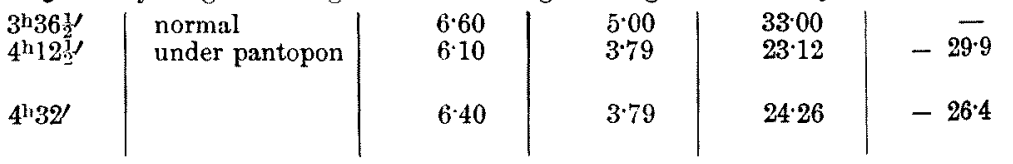

1) Sehüller, Berl. klin. Wochenschr., 1874, 305.

2) Frankfurther and Hirschfeld, Arch. f. (Anatom. u.) Physiol., 1910, 515. 
descended while the blood flow increased, but a similar relation was also observed in the case of the hypodermic injection.

\section{Pantopon.}

A $2 \%$ pantopon solution was injected hypodermically into the rabbit by 2-3 c.c. per kilo of body weight, and when over twenty minutes had passed after the injection, the blood sample was taken. Already in ten minutes after the injection, the effect of the drug appeared ; the respiration became irregular and slower, that is, in succession to every one or two deep respirations, a weak one occurred, and after twenty minutes it became regular, but far slower, namely 2-3 every ten seconds. The heart rate also was slow and sometimes irregular. Further a slight decline of the blood pressure, but no change in the pupils was found, in most cases the corneal reflex was kept up fairly well.

\section{Pantopon.}

VI, A.

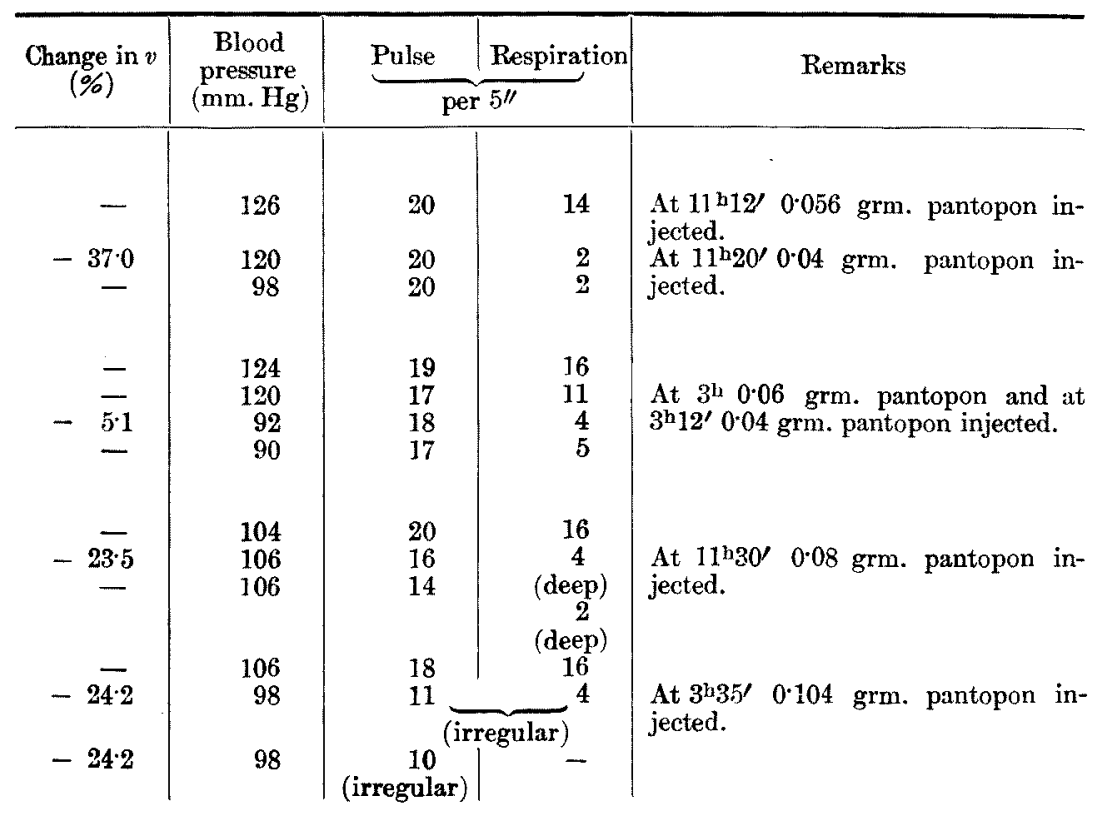




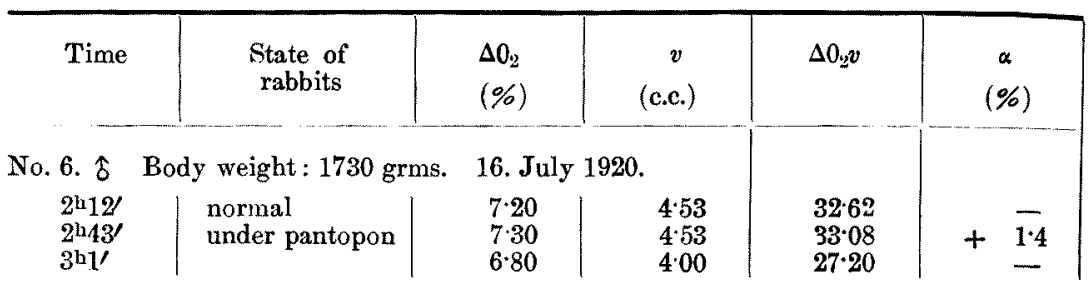

Table

\begin{tabular}{c|c|c|c|c|c|}
\hline Time & $\begin{array}{c}\text { State of } \\
\text { rabbits }\end{array}$ & $\begin{array}{c}\Delta 0_{2} \\
(\%)\end{array}$ & $\begin{array}{c}v \\
(\text { c.c. })\end{array}$ & $\Delta 0_{2} v$ & $\begin{array}{c}\alpha \\
(\%)\end{array}$ \\
\hline
\end{tabular}

No.3. of Body weight: 2000 grms. Brain weight: $9 \cdot 1$ grms. 12. July 1920 .

\begin{tabular}{l|l|l|r|r|r}
$\mathrm{1}^{\mathrm{h}} 51^{\prime}$ & normal & $7 \cdot 06$ & $1 \cdot 34$ & $9 \cdot 46$ & - \\
$2^{\mathrm{h}} 25^{\prime}$ & under pantopon & $7 \cdot 67$ & $1 \cdot 44$ & 11.04 & +16.7 \\
$2^{\mathrm{b}} 51^{\prime}$ & & $9 \cdot 26$ & 0.30 & $2 \cdot 78$ & -
\end{tabular}

No. 7. 5 Body weight: 1950 grms. Brain weight: 9.5 grms. 17. July 1920 .

\begin{tabular}{l|l|l|l|l|l|}
$11^{\mathrm{h} 29}$ & normal & $7 \cdot 20$ & $1 \cdot 79$ & $12 \cdot 89$ & - \\
$12^{\mathrm{h} 5}$ & under pantopon & $9 \cdot 70$ & $2 \cdot 14$ & $20 \cdot 76$ & $+61 \cdot 1$ \\
$12^{\mathrm{L}} 24$ & & $7 \cdot 30$ & $1 \cdot 90$ & $13 \cdot 87$ & $+7 \cdot 6$
\end{tabular}

Pantopon seemed to disturb the gas exchange of the brain a little more than morphine, but its mechanism was nearly the same as that of morphine. In general, in accordance with the decrease in the cerebral blood flow, the oxygen consumption was also reduced. Sometimes, the rate of decrease in the oxygen consumption was greater than that in the blood flow, sometimes they were both unchanged, and in some other cases the oxygen consumption increased parallel with the augmentation of the blood tlow.

Similar to morphine the effect of pantopon on the cerebral vessels was inconstant and not distinct. Both blood pressure and blood flow were unchanged (Exp. 6), both of them were lowered (Exp. 1, 4 \& 8), the blood pressure decreased while the blood flow increased (Exp. $3 \& 7$ ), or the blood pressure was not altered, while the blood flow decreased (Exp. 5); thus the relation between blood flow and blood pressure always being not invariable. 
V, в.

\begin{tabular}{|c|c|c|c|c|}
\hline \multirow{2}{*}{$\begin{array}{l}\text { Change in } v \\
\quad(\%)\end{array}$} & \multirow{2}{*}{$\begin{array}{c}\text { Blood } \\
\text { pressure } \\
\text { (nm. Hg) }\end{array}$} & Pulse & Respiration & \multirow{2}{*}{ Remarks } \\
\hline & & \multicolumn{2}{|c|}{$\underbrace{\prime \prime}_{\text {per } 5 "}$} & \\
\hline \pm & $\begin{array}{l}112 \\
110 \\
108\end{array}$ & $\begin{array}{l}20 \\
11 \\
16\end{array}$ & $\begin{array}{r}16 \\
5 \\
4\end{array}$ & $\begin{array}{l}\text { At } 2^{\text {h } 20} 0.058 \text { grm. pantopon in- } \\
\text { jected. }\end{array}$ \\
\hline
\end{tabular}

V, c.

\begin{tabular}{|c|c|c|c|c|}
\hline $\begin{array}{c}\text { Change in } v \\
(\%)\end{array}$ & $\begin{array}{c}\text { Blood } \\
\text { pressure } \\
(\mathrm{mm} . \mathrm{Hg})\end{array}$ & $\underbrace{\text { Pulse }}_{\text {pe }}$ & $\frac{\text { Respiration }}{5^{\prime \prime}}$ & Remarks \\
\hline $\begin{array}{r}- \\
+\quad 7.5 \\
-\end{array}$ & $\begin{array}{r}104 \\
84 \\
76\end{array}$ & $\begin{array}{c}83 \\
14 \\
\text { (irregular) } \\
18\end{array}$ & $\begin{array}{c}16 \\
2 \\
3 \\
3 \\
\left(\operatorname{per} 10^{\prime \prime}\right)\end{array}$ & $\begin{array}{l}\text { At } 2^{\mathrm{h}} 0^{\circ} 08 \mathrm{grm} \text {. pantopon and at } \\
2^{\mathrm{h}} 10^{\prime} \text { again } .002 \text { grm. injected. } \\
\text { Corneal reflex provoked. }\end{array}$ \\
\hline $\begin{array}{r}- \\
+\quad 18.0 \\
+\quad 6.2\end{array}$ & $\begin{array}{l}98 \\
94 \\
92\end{array}$ & $\begin{array}{l}17 \\
15 \\
15\end{array}$ & $\begin{array}{r}15 \\
4 \\
2\end{array}$ & $\begin{array}{l}\text { At } 11^{h} 40^{\prime} 0.078 \text { grm. pantopon in- } \\
\text { jected. }\end{array}$ \\
\hline
\end{tabular}

So far as the dosage of pantopon selected was between $2 \cdot 0,2 \cdot 5$ and 3.0 c.c. of $2 \%$ solution per kilo of body weight of rabbits, there was observed no difference with regard to the effect on the oxygen consumption and blood flow in the brain.

Thus, the effects of morphine and pantopon on gaseous exchange in the brain were very slight compared with that of chloroform and ether and this conld he actually seen from the nacrotic state of the rabbits.

\section{SCopolamine and SCoplamine-Morphine.}

Of scopolaminum hydrobromicum $0.2 \%$ solution in $\mathrm{Ringer}$ was injected hypodermically into the rabbit in the ratio of 2 c.c. per kilo of body weight. Drawing of blood samples and measurement of gaseous exchange were done before the injection and more than 20 minutes after. 
Effect of

TAare

\begin{tabular}{c|c|c|c|c|c}
\hline Time & \begin{tabular}{c|c}
$\Delta 0_{2}$ \\
$(\%)$
\end{tabular} & $\begin{array}{c}v \\
(c . c .)\end{array}$ & $\Delta 0_{2} v$ & $\alpha$ & $\begin{array}{c}\text { Change in } v \\
(\%)\end{array}$ \\
\hline
\end{tabular}

No. 1. \& Body weight: 1830 grms. Brain weight: $9 \cdot 2$ grms. 10. Aug. 1920 .

\begin{tabular}{l|l|l|l|r|r}
$3^{\mathrm{L}} 23^{\prime}$ & 1070 & 271 & 27.21 & - & - \\
$3^{\mathrm{h}} 58^{\prime}$ & 12.30 & 2.34 & 28.78 & +5.8 & -13.7 \\
$4^{\mathrm{h}} 22^{\prime}$ & 12.00 & 1.42 & 17.04 & - & -
\end{tabular}

No. 2. $\hat{o}$ Body weight: $1900 \mathrm{grm}$. Brain weight: 93 grms. 12. Aug. 1920.

\begin{tabular}{l|r|r|r|r|r}
$10^{\mathrm{b}} 47^{\prime}$ & 5.92 & 5.47 & 32.38 & - & - \\
$11^{\mathrm{h}} 17^{\prime}$ & 10.00 & 330 & 33.00 & +1.9 & -39.7 \\
$11^{\mathrm{h}} 36^{\prime}$ & 1270 & 233 & 2959 & -8.6 & -57.4
\end{tabular}

No. 3. \& Body weight: 2270 grms. Brain weight: $8 * 6$ grms. 24. Aug. 1920 .

\begin{tabular}{|l|l|l|l|r|r|}
$4^{\mathrm{h}} 0^{\prime}$ & $10 \cdot 60$ & $6 \cdot 48$ & $68 \cdot 69$ & - & - \\
$4^{\mathrm{h}} 10^{\prime}$ & $15 \cdot 20$ & $4 \cdot 21$ & 63.99 & $-6 \cdot 8$ & $-35 \cdot 0$ \\
$4^{\mathrm{h}} 51^{\prime}$ & 14.20 & $3 \cdot 87$ & 54.95 & - & -
\end{tabular}

There were no noticeable effects on blood pressure, respiration, cardiac apex-beat, nor on corneal reflex, except that the pupils often became enlarged (Table VII).

Next scopolamine was used in combination with morphine as follows:

$0.01 \mathrm{grm}$. morphinum hydrochloricum and 0.0004 grm. scopolaminum hydrobromicum were dissolved in l c.c. Ringer's solution.

When this solution was injected hypodermically in the proportion of 2 c.c. per kilo of body weight, the blood pressure did not remarkably decrease, and the effect on the heart beat and respiration did not differ from that of morphine alone; the corneal reflex was always preserved. Deep narcosis such as by chloroform or ether could not be produced. (Table VIII). 


\section{Scopolamine.}

VII.

\begin{tabular}{|c|c|c|c|}
\hline $\begin{array}{c}\text { Blood } \\
\text { pressure } \\
(\mathrm{mm} . \mathrm{Hg})\end{array}$ & Pulse & $\frac{\text { Respiration }}{5^{\prime \prime}}$ & Remarks \\
\hline 128 & 20 & 18 & At $3^{\mathrm{h}} 30^{\prime} 0.0072 \mathrm{grm}$. scoplamine injected. \\
\hline 122 & 20 & 11 & \\
\hline 112 & 20 & 13 & \\
\hline 116 & 16 & 6 & At $10^{\mathrm{h}} 55^{\prime} 0.0076 \mathrm{grm}$. scopolamine injected. \\
\hline 110 & 19 & 6 & Large pupils. \\
\hline 110 & 19 & 5 & Large pupils. \\
\hline 100 & 24 & 20 & At $4^{\mathrm{h}} 10^{\prime} 0.0088 \mathrm{grm}$, scopolamine injected. \\
\hline 90 & 20 & 16 & \\
\hline 86 & 22 & 16 & \\
\hline
\end{tabular}

The scopolamine slightly reduced the blood flow through the brain, but caused no change in the oxygen consumption; there was no noticeable depressant effect on the nerve cells. The descent of the blood flow followed the descent of arterial blood pressure. Frankfurther and Hirsch feld $d^{1)}$ also observed no distinct effect of scopolamine on cerebral vessels.

1) Frankfurther and Hirschfeld, l.c. 
Effect of Morphine

TABLE

\begin{tabular}{c|c|c|c|c|c|}
\hline Time & $\begin{array}{c}\text { State of } \\
\text { rabbits }\end{array}$ & $\begin{array}{c}\Delta 0_{2} \\
(\%)\end{array}$ & $\begin{array}{c}v \\
\text { (c.c.) }\end{array}$ & $\Delta 0_{2} v$ & $\begin{array}{c}\alpha \\
(\%)\end{array}$ \\
\hline
\end{tabular}

No. 1. 今 Borly weight: 2070 grms. Brain weight: 8.9 grms. 30. Aug. 1920 .

\begin{tabular}{|l|l|}
$1^{\mathrm{b}} 55^{\prime}$ & $\begin{array}{l}\text { normal } \\
\text { under scopolamine- } \\
\text { morphine }\end{array}$
\end{tabular}

No. 2. B Body weight: 2000 grms.

\begin{tabular}{r|c}
$9 \mathrm{~h} 55^{\prime}$ & $\begin{array}{c}\text { normal } \\
10^{\mathrm{h}} 31^{\prime}\end{array}$ \\
$10^{\mathrm{h}} 51^{\prime}$ & $\begin{array}{c}\text { under scopolamine- } \\
\text { morphine } \\
, "\end{array}$
\end{tabular}

No. 3. \& Body weight : 2050 grms.

\begin{tabular}{l|l|}
$8 \cdot 48$ & $0 \cdot 69$ \\
4.30 & $0 \cdot 44$
\end{tabular}

Prain weight : $9 \cdot 0$ grms.

\begin{tabular}{l|l|}
\hline $8 \cdot 18$ & $4 \cdot 86$ \\
$7 \cdot 19$ & $2 \cdot 44$ \\
\hline $6 \cdot 12$ & $2 \cdot 07$
\end{tabular}

Brain weight: $9 \cdot 1$ grms

\begin{tabular}{|c|c|c|c|c|c|}
\hline $11^{\mathrm{l}} 11^{\prime}$ & normal & $7 \cdot 56$ & $5 \cdot 39$ & $40 \cdot 75$ & - \\
\hline 1.1 $175^{\prime}$ & under scopolamine- & $5 \cdot 56$ & $5 \cdot 11$ & $28 \cdot 41$ & -303 \\
\hline $12^{\mathrm{h}} 3 \frac{1}{2}$ & $"$, & $7 \cdot 63$ & $1 \cdot 43$ & 10.91 & - \\
\hline
\end{tabular}

588

$1 \cdot 87$

$-68 \cdot 2$

In the case of scopolamine-morphine, though the corneal reflex was kept up, the oxygen consumption in the brain was very distinctly reduced, not less than in the case of chlornform or ether. In some cases the blood flow descended concomitant with the descent of the arterial blood pressure, in some cases both blood pressure and blood flow did not change; however even in the case of unchanged blood flow, the disturhance of gaseous exchange in the brain was very great. Generally, the value of $40_{2}$ usually increases accompanyied by the decrease in the blood flow $v$, but in this case it decreased, so that the rate of the decreases in the oxygen consumption was far greater than that in the blood flow. That the effect of morphine on the gaseous metabolism of the brain is angmented by its combination with scopolamine, is presumably not due to a special effect on the circulation, but is directly due to the acceleration of the action of morphine on the central nervous system by scopolamine. And in this case the disturbance of gaseous exchange was exceedingly marked in comparison with the only slight depression of the brain.

In the experiments of scopolamine-morphine, the dosis of morphine was one half of the amount used in the experiment with morphine alone, and that of scopolamine was only one fifth of that used in the experiments witl scopolamine. Scopolamine alone caused no change in the gaseous exchange of the braiu, even when used in five times the quan- 
and Scopolamine.

VIII.

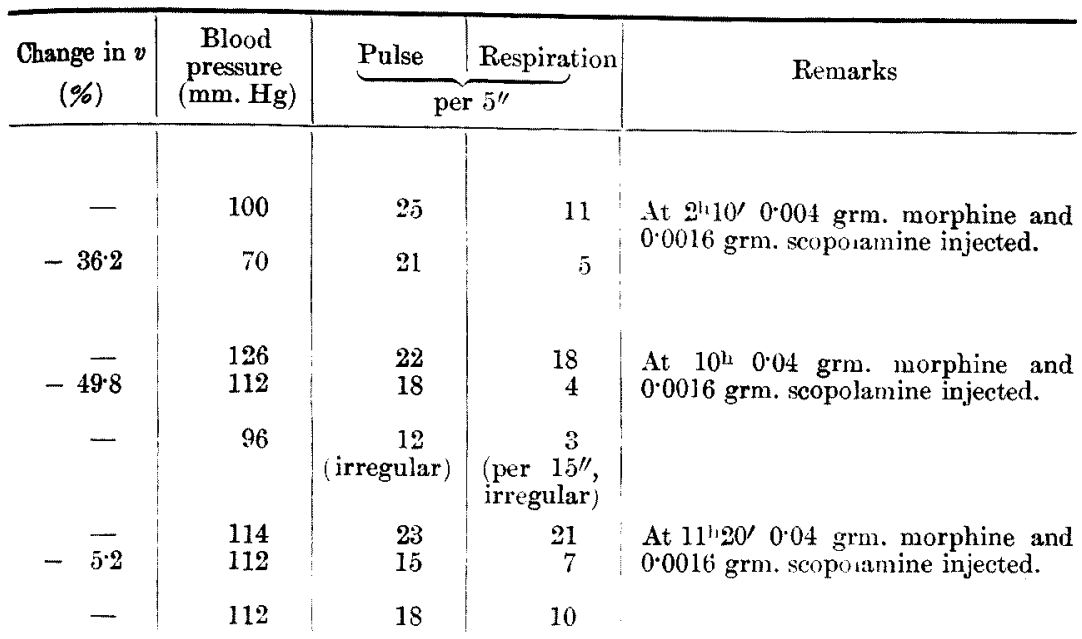

tity used in the case of combination with morphine, and in the morphine experiments there was only a very slight reduction of it, though using twice as much, whereas the combination of both drugs in so small dosage produced a marked disturbance of oxygen consumption in the brain. In analogy with the multiplied narcotic effect of a combination of different anaesthetics which is often evidenced in other animal experiments, the action on cerebral gaseous exchange is greatly exaggerated when they are combined in use.

\section{Magnesium and Calcium.}

Since Meltzer and $\mathrm{A} u$ er ${ }^{1)}$ demonstrated that subcutaneous or intravenous injection of magnesium salts caused a state of anaesthesia and paralysis, which was however reversed and completely restored by the injection of various calcium salts, there has been a great deal of work done on the antagonism existing between the effects of calcium and magnesium, but similar research with regilrd to the gaseous exchange in the brain has only been reported by Alexander and Csernat, the

1) Meltzer and Auer, Amer. Journ. Physiol, 1908, 21, 400.

2) Alexander and Cserna, l, c. 
results of whose experiments will below be discussed. Now, measuring the change in the oxygen intake and blood flow in the brain of rabbits causer by the administration of magnesium and calcium, I attempted to investigate the antagonistic relation between these two salts existing in the central function. $\quad 5-7 \frac{1}{2}$ c.c. per kilo of $25 \%$ solution of magnesium sulphate were hypodermically injected into rabbits and blood samples collected after its inhibitory effects had distinctly appeared, and again after complete recovery was brought about by an intravenous injection of $3 \%$ calcium chloride by $2 \frac{1}{2}-4$ c.c. per kilo. In Alexander

Effect of Magnesium

TABLE

\begin{tabular}{c|c|c|c|c|c|}
\hline Time & $\begin{array}{c}\text { State of } \\
\text { rabbits }\end{array}$ & $\begin{array}{c}\Delta 0_{2} \\
(\%)\end{array}$ & $\begin{array}{c}v \\
(\text { c.c. })\end{array}$ & $\Delta 0_{2} v$ & $\begin{array}{c}\alpha \\
(\%)\end{array}$ \\
\hline
\end{tabular}

No. 1. ㅇ Body weight : 2200 grms. Brain weight: 4.0 grms. 1. June 1921 .

\begin{tabular}{l|l|l|l|l|c}
$2^{\wedge} 22^{\prime}$ & normal & $9 \cdot 30$ & $3 \cdot 21$ & $29 \cdot 85$ & - \\
$2^{1} 555^{\prime}$ & narcotic & $5 \cdot 10$ & $3 \cdot 84$ & $19 \cdot 58$ & $-34 \cdot 4$
\end{tabular}

No. 2. 우 Body weight : 2200 grms. Brain weight: 8.7 grms. 3. June 1921.

\begin{tabular}{l|l|l|l|r|r}
$7^{\mathrm{b}} 58^{\prime}$ & normal & $5^{*} 40$ & $2 \cdot 15$ & 11.61 & - \\
$8^{\mathrm{L}} 37^{\prime}$ & narcotic & $5 \cdot 40$ & 0.34 & 1.84 & $-84 \cdot 2$ \\
$9^{\mathrm{h}} 15^{\prime}$ & awakened & $6 \cdot 00$ & 0.33 & 1.98 & -82.9
\end{tabular}

No.:. \& Body weight: 2050 grms. Brain weight: 8.9 grms. 4. June 1921 .

\begin{tabular}{l|l|r|r|r|r}
$8^{\mathrm{h}} 11^{\prime}$ & normal & $9 \cdot 60$ & 4.80 & 46.08 & - \\
$9^{\mathrm{L}} y^{\prime}$ & nareotic & - & 0.26 & - & - \\
$9^{\mathrm{h}} 15^{\prime}-9^{\mathrm{h}} 39 g^{\prime}$ & awakened & - & 0.26 & - & -
\end{tabular}

No. 4. oิ Body weight: 1980 grms. Brain weight: 8.9 grms. 5. June 1921 .

\begin{tabular}{l|l|r|r|r|r|}
$3^{\mathrm{b}} \boldsymbol{2}$ & normal & $6 \cdot 50$ & $7 \cdot 50$ & $48 \cdot 75$ & - \\
$3^{\mathrm{h}} 52 \mathrm{2}$ & narcotic & $8 \cdot 40$ & $4 \cdot 12$ & $34 \cdot 61$ & $-29 \cdot 0$ \\
$4^{\mathrm{h}} 14^{\prime}$ & awakened & $10 \cdot 10$ & $1 \cdot 42$ & $14 \cdot 34$ & $-70 \cdot 6$
\end{tabular}


and Cserna's experiments magnesium was administered intravenously, but in my experiment subcutaneously, because the intravenons injection produced so severe effects on the respiration and circulation, that it was not suitable for the measurement of the blood gas (Table IX).

\section{and Calcium.}

IX.

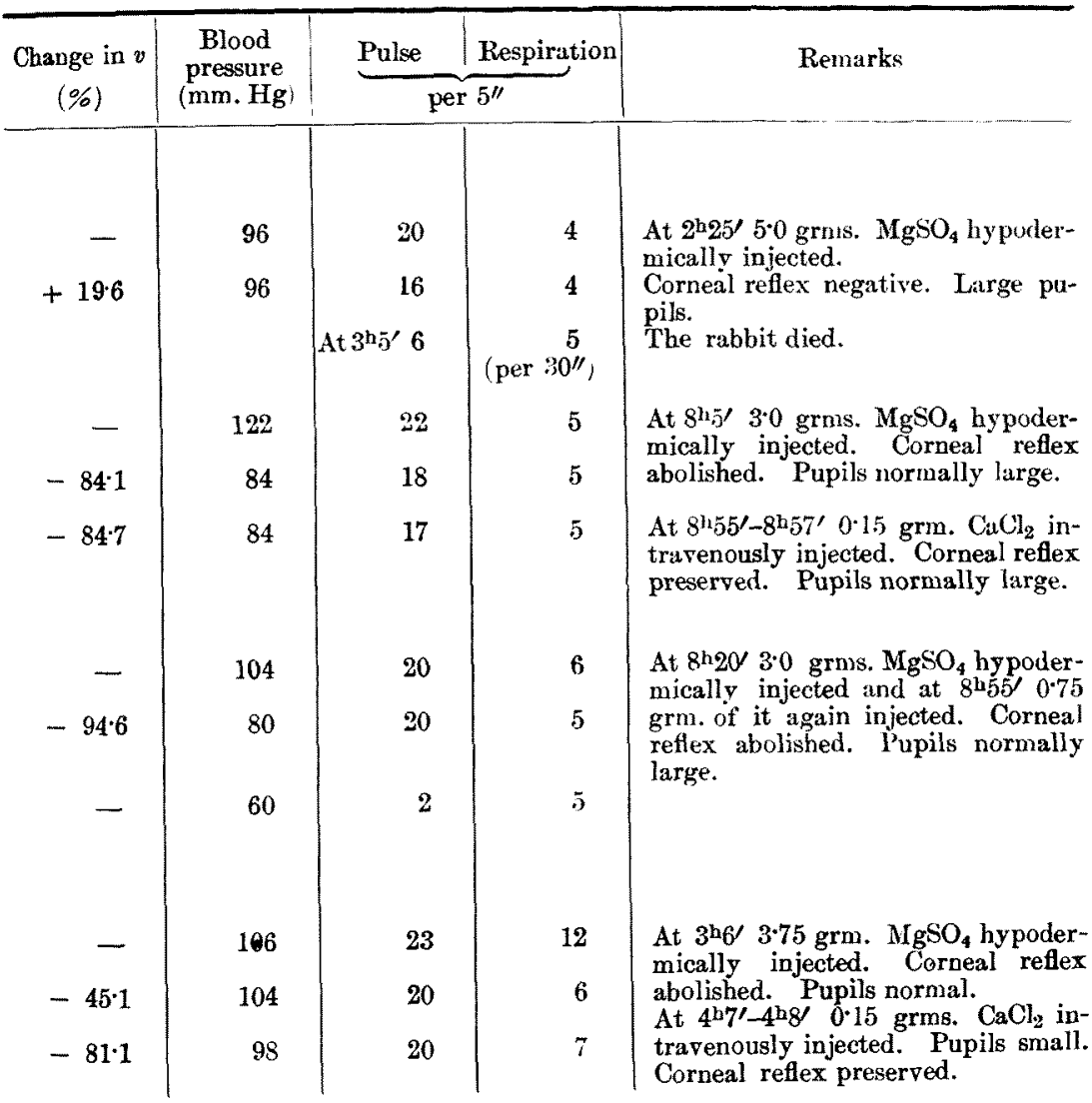


Magnesium sulphate subcutaneously administered caused no convulsion or other exciting state, but after 20-30 minutes loss of corneal reflex and total paralysis. In most of my experiments the arterial blood pressure descended, but respiration was scarcely disturbed. The blood flow through the brain diminished in accordance with the descent of arterial blood pressure, but sometimes was accompanied by no change in this; in the latter case it may be presumed that the brain vessels have contracted somewhat. Alexander and $\mathrm{Cser} n \mathrm{a}^{1)}$ announced an active dilation of the brain vessels followed by contraction. In my experiments only Exp. 1 showed an increase in blood flow at the later stage of narcosis, probably owing to the passive dilation of the cerebral vessels caused by the ascent of the general venous pressure; at this period the arterial blood pressure suddenly descended while taking the blood and the rabbit died in a short time on account of the pronounced depressant effects on the respiration and the heart.

As to gaseous metabolism of the brain in magnesium narcosis, Alexander and Cserna ${ }^{1)}$ observed no change or even increase in the oxygen intake, but in my experiments there was always a marked diminution, the rate of which was not less than that in the case of ether or chloroform narcosis. And this decrease in the oxygen consumption was nearly always accompanied by the reduction of blood flow. The rate of the decrease in both was about parallel, but in some cases the gaseons exchange only was disturbed without any change in the blood flow. Furthermore, Alexauder and Cserna $a^{1)}$ stated that reversing the paralytic effects of magnesium by an injection of calcium chloride, restored the oxygen consumption to its normal value, an announcement which did not agree again with my results. The intravenous injection of calcium into the rabbit in magnesium narcosis caused no noticeable change in the heart rate or the respiration, only the corneal reflex reappeared during the injection. The cerebral oxygen consumption and the blood flow which were measured 5-20 minutes after the injection either did not change or often decreased. Thus, caicium salt restored the functional activity of the brain in a short time, but not the oxygen consumption.

As already mentioned, in the reconvalescent stage of ether or chloroform narcosis, the oxygen consumption reached again the normal level or at least showed a tendency to restore, unless extreme reduction

1) Alexander and Cserna, l. c. 
in the blood flow checked it. On the contrary, in the reconvalescence of magnesium narcosis brought about by the injection of calcium, the oxygen consumption remained decreased as in the paralytic stage or sometimes diminished more hand in hand with increasing reduction in the blood flow ; an evidence, that calcium hardly restores the decreased oxygen consumption of the brain caused by magnesium narcosis. When nerve cells have once been subjected to the action of drugs, the balance between the energy exchange and the activity of the cells cannot be maintained, especially in the reconvalescent stage of narcosis.

Next the influence of calsium salt alone upon the gaseous metabolism of the brain in normal rabbits was to be observed (Table $\mathrm{X}$ ). Calcium salts decrease oxidation in the muscles and the spinal cord of frogs (Thumbergì and Unger ${ }^{2}$ ), and produce a disturbance of sugar metabolism, but an increase in nitrogen metabolism (Hirschberg and $W$ interstein $\left.{ }^{3 /}\right)$. But my experiments in which calcium chloride was administered intravenously into normal rabbits proved no change or only a slight decrease in the oxygen consumption, as illustrated in Table $\mathrm{X}$. No effect on corneal reflex, respiration or blood pressure was found. In most cases the blood flow through the brain did not change, sometimes it decreased only slightly. The miosis which was olserved on injecting calcium into rabbits made narcotic with magnesium was not demonstrable in the case of normal rabbits.

Thus, calcium is rather an inhibitory agent for the brain from the standpoint of gaseous exchange. According to the report of MeItzer and $A u e r^{4}$, calcium injected intravenously is capable of neutralizing only that part of the magnesium which it finds already absorbed from the subcutaneous tissues. But since the magnesium continues to be absorbed after the injection of calcium, the animal lies in a new anaesthetic and relaxed state for hours. The reason why the oxygen consumption in the awakening state due to calcium in magnesium narcosis was not restored, might be partly attributed to this relixed state of the rabbit, but also to the inhibitory effect on the gaseous exchange of calcium itself. Increase in either $\mathrm{Ca}$ or $\mathrm{Mg}$ ions depresses nervous structures. Nevertheless, the effects of $\mathrm{Mg}$ may be removed by addition of Ca.

1) Thumberg, Nkand. Arch. f. Physiol., 1909, 22, 406 and ibid. 1910, 24, 62.

2) Unger, Bioch. Zeitschr., 1914, 61, 103.

3) Hirschberg and Winterstein, Zeitschr. f. physiol. Chem., 1918, 101, 212.

4) Meltzer and Auer, l. c. 


\section{Effect of}

TABLE

\begin{tabular}{c|c|c|c|c|c|}
\hline \multirow{2}{*}{ Time } & \begin{tabular}{c|c|c|c}
$\Delta 0_{z}$ \\
$(\%)$
\end{tabular} & $\begin{array}{c}v \\
\text { (c.c.) }\end{array}$ & $\Delta 0_{2} v$ & $\begin{array}{c}\alpha \\
(\%)\end{array}$ & $\begin{array}{c}\text { Change in } v \\
(\%)\end{array}$ \\
\hline
\end{tabular}

No. 5. S Body weight: 1950 grms. Brain weight: $8^{\circ} 0$ grms. 6. June 1921.

\begin{tabular}{l|l|l|l|r|r}
$7 \mathrm{~b} 50^{\prime}$ & $8 \cdot 71$ & 2.67 & $23 \cdot 26$ & - & - \\
$8^{\mathrm{h}} 12^{\prime}$ & 6.70 & 1.76 & $11 \cdot 79$ & $-49 \cdot 3$ & $-34 \cdot 1$ \\
$8^{\mathrm{h}} 32^{\prime}$ & $7 \cdot 90$ & 1.68 & $13 \cdot 27$ & - & -
\end{tabular}

No.6. ㅇ Body weight: 2420 grms. Brain weight: 10.5 grms. 16. June 1921 .

\begin{tabular}{l|l|l|l}
$10^{\mathrm{l}} 0^{\prime}$ & $7 \cdot 40$ & $1 \cdot 05$ & $7 \cdot 77$ \\
$10^{\mathrm{h}} 26^{\prime}$ & $5 \cdot 60$ & $1 \cdot 04$ & $5 \cdot 82$ \\
$10^{\mathrm{h}} 42^{\prime}$ & $6 \cdot 80$ & $1 \cdot 19$ & $8 \cdot 09$ \\
$10^{\mathrm{h}} 58^{\prime}$ & $6 \cdot 10$ & $1 \cdot 01$ & $6 \cdot 16$
\end{tabular}

No. 7. 우 Body weight: 1940 grms. 22. June 1921 .

\begin{tabular}{l|c|c|r|r|r}
$7^{\mathrm{h}} 43^{\prime}$ & 1.20 & 7.06 & 8.47 & - & - \\
$7^{\mathrm{h}} 58^{\prime}$ & 1.20 & 8.89 & 10.67 & - & - \\
$8^{\mathrm{h}} 222^{\prime}$ & - & $9 \cdot 11$ & - & - & +25 \\
$8^{\mathrm{h}} 37^{\prime}$ & - & 6.32 & - & - & -28.7
\end{tabular}

No. 8. 우 Body weight: 2000 grms. Brain weight : 8.5 grms. 23. June 1921 .

\begin{tabular}{|c|c|c|c|c|c|c|}
\hline $7^{\mathrm{h}} 58$ & $7 \cdot 30$ & $2 \cdot 47$ & 16.0 & & - & - \\
\hline $8^{\mathrm{h}} 27$ & $8 \cdot 20$ & 1.90 & $15 \cdot 58$ & - & 28 & -231 \\
\hline $8^{11} 47^{\prime}$ & 8.00 & 2.03 & 16.24 & + & $1: 3$ & 13.8 \\
\hline
\end{tabular}

No. 9. 우 Body weight: 2020 grms. Brain weight: 8.3 grms. 25. June 1921.

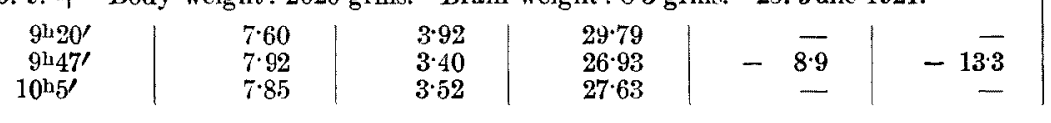

About magnesium anaesthesia it is generally accepted that magnesium salts cause a reversible change in the protoplasma membrane without entering the nervous cells and this change has an inhibitory effect on the cells (Stransky'), Mansfeld and Bosán $y^{2)}$ ).

On the basis of Warburg' $s^{3}$ experiments that sodium hydrate augmented the oxygen consumption of the cells without penetrating them, A lexander and $\mathrm{C}$ sern $\mathrm{a}^{4)}$ explained that magnesium sulphate had a similar, but contrary action, and it could be suspended by the in-

1) Stransky, Arch. f. exp. Pathol. u. Pharmakol., 1915, 78, 122.

2) Mansfeld and Bosány, Pflüger's Arch., 1913, 152, 75.

3) Warburg, l. c.

4) Alexander and Cserna, l. c. 


\section{Calcium.}

$\mathbf{X}$.

\begin{tabular}{|c|c|c|c|}
\hline $\begin{array}{l}\text { Blood } \\
\text { pressure } \\
\text { (mn. Hg) }\end{array}$ & Pulse & $\frac{\text { Respiration }}{5^{\prime \prime}}$ & Remarks \\
\hline 108 & 17 & 7 & At $8^{\mathrm{h}} 6^{\prime}$ pulse rate 17 , respiration 4 \\
\hline 108 & 19 & 4 & $\begin{array}{l}\text { At } 8^{\mathrm{h}} 7^{\prime}-8^{\mathrm{h}} 8 \mathrm{~d} 0 \cdot 2 \mathrm{grm} . \mathrm{CaCl}_{2} \text { intravenously } \\
\text { injected. Corneal reflex and pupils normal. }\end{array}$ \\
\hline 100 & 18 & 5 & \\
\hline 88 & 20 & 12 & $\begin{array}{l}\text { At } 10^{\mathrm{h}} 19^{\prime}-10^{\mathrm{h}} 2 \mathrm{y}^{\prime} \\
\text { venously injected. }\end{array}$ \\
\hline $\begin{array}{l}88 \\
88 \\
84\end{array}$ & $\begin{array}{l}20 \\
20 \\
21\end{array}$ & $\begin{array}{r}12 \\
8 \\
7\end{array}$ & Corneal reflex and pupils normal. \\
\hline $\begin{array}{l}95 \\
95 \\
95 \\
90\end{array}$ & $\begin{array}{l}23 \\
23 \\
22 \\
22\end{array}$ & $\begin{array}{l}13 \\
13 \\
11 \\
11\end{array}$ & $\begin{array}{l}\text { At } 8^{\mathrm{h}} 12 /-8^{\mathrm{h}} 17^{\prime} \\
\text { ly injected. Corneal reflex and pupils } \\
\text { norml. }\end{array}$ \\
\hline $\begin{array}{l}108 \\
106 \\
106\end{array}$ & $\begin{array}{l}20 \\
20 \\
20\end{array}$ & $\begin{array}{r}14 \\
13 \\
6\end{array}$ & $\begin{array}{l}\text { At } 8^{\mathrm{h}} 1 \mathrm{~S}^{\prime}-8^{\mathrm{h}} 20^{\prime} 0.24 \mathrm{grm} . \mathrm{CaCl}_{\mathrm{g}} \text { intravenous- } \\
\text { ly injected. Pupils normal. Corneal reflex } \\
\text { normal. }\end{array}$ \\
\hline $\begin{array}{l}102 \\
100 \\
100\end{array}$ & $\begin{array}{l}21 \\
21 \\
21\end{array}$ & $\begin{array}{l}8 \\
7 \\
7\end{array}$ & $\begin{array}{l}\text { At } 9^{\mathrm{h}} 40^{\prime}-9^{\mathrm{h}} 42 / 0.24 \mathrm{grm} . \mathrm{CaCl}_{2} \text { intravenous- } \\
\text { ly injected. Pupils normal. Corneal reflex } \\
\text { normal. }\end{array}$ \\
\hline
\end{tabular}

jection of calcium chloride, and recognized with Warburg that the change in the state of protoplasma membrane had a strong influence on oxidation in the interior of the cells.

However, in my experiments, as mentioned above, the function of the cells was promptly restored by a calcium injection, but the disturbance of oxygen consumption still continued. This evidence suggests that in the reconvalescent stage of narcosis due to various drugs the oxygen consumption in the brain was generally disturbed more than the cerebral function, and there is antagonism between the effects of calcium and magnesium ions on the activity of the brain, but not on the gaseous exchange in it. It follows then that a direct relation between the oxidative process and the excitability of the brain does not necessarily exist. 


\section{Chloral Hydrate.}

Since I could find no report about the effect of hypnotics upon the gaseous metabolism and circulation in the brain, my next investigation was made on this subject, and the action of various kinds of hypnotics was compared with that of narcotics. First of all, chloral

Effect of

TABLE

\begin{tabular}{|c|c|c|c|c|c|}
\hline Tinse & $\begin{array}{c}\text { State of } \\
\text { rabbits }\end{array}$ & $\begin{array}{c}\Delta 0_{2} \\
(\%)\end{array}$ & $\begin{array}{c}v \\
(\text { c.c. })\end{array}$ & $\Delta 0_{2} v$ & $\begin{array}{c}\alpha \\
(\%)\end{array}$ \\
\hline
\end{tabular}

No. 2. \& Body weight: 2070 grms. Brain weight: 9.5 grms. 7. Sept. 1920 .

\begin{tabular}{l|c|c|c|c|r}
$3^{\mathrm{h}} 16^{\prime}$ & normal & $5 \cdot 52$ & $7 \cdot 27$ & $40 \cdot 13$ & - \\
$3^{\mathrm{\nu}} 40^{\prime}$ & sleeping & $3 \cdot 49$ & $7 \cdot 06$ & 24.64 & $-38 \cdot 6$ \\
$3^{\mathrm{\nu}} 58^{\prime}$ & $"$ & $6 \cdot 74$ & $3 \cdot 56$ & 28.99 & $-40 \cdot 2$
\end{tabular}

No. 3. 우 Body weight: 2280 grms. Brain weight: 8.5 grms. 9. Sept. 1920 .

\begin{tabular}{l|l|l|l|l|r}
$10^{\mathrm{h}} 56^{\prime}$ & normal & 8.20 & 0.66 & 5.41 & - \\
$11^{\mathrm{h}} 29^{\prime}$ & sleeping & $5 \cdot 78$ & 0.71 & 4.10 & $-24 \cdot 2$ \\
$11^{\mathrm{h}} 50^{\prime}$ & normal & $5 \cdot 93$ & 1.07 & 6.35 & -
\end{tabular}

No. 5. o Body weight: 2360 grms. Brain weight: 8.5 grms. 18. Sept. 1920.

\begin{tabular}{l|c|c|c|c|c}
$11^{\mathrm{h}} 46^{\prime}$ & normal & $10 \cdot 22$ & 275 & $28 \cdot 11$ & - \\
$12^{\mathrm{h}} 17^{\prime}$ & sleeping & $6 \cdot 78$ & 273 & $18 \cdot 31$ & $-34 \cdot 2$ \\
$12^{\mathrm{h}} 36^{\prime}$ & $"$ & $5 \cdot 14$ & $1 \cdot 18$ & 6.07 & $-78^{\circ}$
\end{tabular}

No. 6. 오 Body weight: 2620 grms. Britin weight: 9·4 grms. 23. Sept. 1920 .

\begin{tabular}{l|l|l|l|l|r}
$10^{\mathrm{h}} 24^{\prime}$ & normal & 8.74 & 2.47 & 21.59 & - \\
$10^{\mathrm{h} 52^{\prime}}$ & sleeping & $8.0 \mathrm{~S}$ & $2 \cdot 17$ & 17.53 & -18.8 \\
$11^{\mathrm{b} 9}$ & normal & 9.34 & 1.80 & 16.81 & -22.1
\end{tabular}

No. 8. \& Body weight: 2170 grms. Brain weight: 9.0 grms. 3. Oct. 1920.

\begin{tabular}{l|l|l|l|l|r|}
$4^{\mathrm{h}} 53^{\prime}$ & normal & 7.00 & 4.57 & 31.99 & - \\
$5^{\mathrm{l} 21^{\prime}}$ & sleeping & 4.50 & 4.80 & 21.60 & -32.8 \\
$5^{\mathbf{L} 45^{\prime}}$ & normal & 9.83 & 1.61 & 15.83 & -
\end{tabular}


hydrate was used as a hypnotic containing halogen. A $5 \%$ solution of chloral hydrate was slowly injected into the jugular vein of rabbits by 5 c.c. per kilo of body weight. The data of the experiments are tabulated below (Tables XI) :

\section{Chloral Hydrate.}

XI, A.

\begin{tabular}{|c|c|c|c|c|}
\hline $\begin{array}{c}\text { Change in } v \\
(\%)\end{array}$ & $\begin{array}{c}\text { Blood } \\
\text { pressure } \\
\text { (mm. Hg) }\end{array}$ & Pulse & $\frac{\text { Respiration }}{5^{\prime \prime}}$ & Remarks \\
\hline $\begin{array}{r}- \\
-\quad 2 \cdot 9 \\
-51 \cdot 0\end{array}$ & $\begin{array}{l}92 \\
90 \\
56\end{array}$ & $\begin{array}{l}25 \\
23 \\
22\end{array}$ & $\begin{array}{r}18 \\
3 \\
3\end{array}$ & $\begin{array}{l}\text { At } 3^{\mathrm{h}} 33^{\prime}-3^{\mathrm{h}} 35^{\prime} \quad 0.5 \text { grm. chloral } \\
\text { hydrate injected. } \\
\text { Corneal reflex abolished. Pupils } \\
\text { large. } \\
\text { No corneal reflex. Pupils large. }\end{array}$ \\
\hline $\begin{array}{r}- \\
+\quad 7 \cdot 6 \\
-\end{array}$ & $\begin{array}{l}88 \\
64 \\
68\end{array}$ & $\begin{array}{l}22 \\
23 \\
23\end{array}$ & 19 & $\begin{array}{l}\text { At } 11^{\mathrm{b}} 14-11^{\mathrm{b}} \mathrm{k} 6^{\prime} \\
\text { hydrate injected. } \\
\text { Corneal reflex negative. } \\
\text { Comeal reflex and sensation of pain } \\
\text { preserved. }\end{array}$ \\
\hline $\begin{array}{r}- \\
-\quad 07 \\
-57 \cdot 1\end{array}$ & $\begin{array}{l}98 \\
68 \\
72\end{array}$ & $\begin{array}{l}22 \\
22 \\
22\end{array}$ & $\begin{array}{l}6 \\
6 \\
6\end{array}$ & $\begin{array}{l}\text { At } 12^{\mathrm{h}} 5^{\prime}-12^{\mathrm{h}} 7^{\prime} 0.5 \mathrm{grm} \text {. chloral hy- } \\
\text { drate injected. } \\
\text { No corneal reflex and sensation of } \\
\text { pain. } \\
\text { No corneal reflex. Pupils normally } \\
\text { large. }\end{array}$ \\
\hline $\begin{array}{r}- \\
-12 \cdot 3 \\
-27 \cdot 1\end{array}$ & $\begin{array}{l}92 \\
70 \\
62\end{array}$ & $\begin{array}{l}18 \\
22 \\
22\end{array}$ & $\begin{array}{r}12 \\
7 \\
12\end{array}$ & $\begin{array}{l}\text { At } 10^{\mathrm{h}} 42^{\prime}-10^{\mathrm{h}} 44^{\prime} \\
\text { hydrate injected. } \\
\text { Corneal reflex negative. Pupils } \\
\text { large. } \\
\text { Corneal reflex scarcely provoked. } \\
\text { Pupils normally large. }\end{array}$ \\
\hline $\begin{array}{r}- \\
+\quad 5 \cdot 3 \\
-\end{array}$ & $\begin{array}{l}92 \\
78 \\
72\end{array}$ & $\begin{array}{l}22 \\
21 \\
22\end{array}$ & $\begin{array}{r}13 \\
4 \\
4\end{array}$ & $\begin{array}{l}\text { At } 5^{\mathrm{h}} 15^{\prime}-5^{\mathrm{h}} 17^{\prime} 0^{\circ} 45 \text { grm. chloral } \\
\text { hydrate injected. During the injec- } \\
\text { tion pupils small, afterwards normal- } \\
\text { ly large. } \% \text { after the injection cor- } \\
\text { neal reflex abolished. From } 5^{\mathrm{b}} 30^{\prime} \\
\text { on corneal reflex provoked. }\end{array}$ \\
\hline
\end{tabular}


Tamle

\begin{tabular}{|c|c|c|c|c|c|}
\hline Time & $\begin{array}{l}\text { State of } \\
\text { rabhits }\end{array}$ & $\begin{array}{l}\Delta 0_{2} \\
(\%)\end{array}$ & $\begin{array}{c}v \\
\text { (c.c.) }\end{array}$ & $\Delta 0_{2} v$ & $\begin{array}{c}\alpha \\
(\%)\end{array}$ \\
\hline No.4. 우 & Body weight : 2270 grms. & \multicolumn{2}{|c|}{ Brain weight: 8.5 grms. } & \multicolumn{2}{|c|}{ 11. Sept. 1920.} \\
\hline $4^{\text {h } 58^{\prime}}$ & normal & $8 \cdot 78$ & $4 \cdot 10$ & $36 \cdot 00$ & - \\
\hline $5^{\mathrm{h}} 17^{\prime}$ & ” & $9 \cdot 04$ & $3 \cdot 38$ & $30 \cdot 56$ & - \\
\hline $5^{\text {h }} 52$ & sleeping & $2 \cdot 37$ & $5 \cdot 92$ & 14.03 & -541 \\
\hline $6^{\mathrm{h}} 15^{\prime}$ & & & & & \\
\hline
\end{tabular}

TABLE

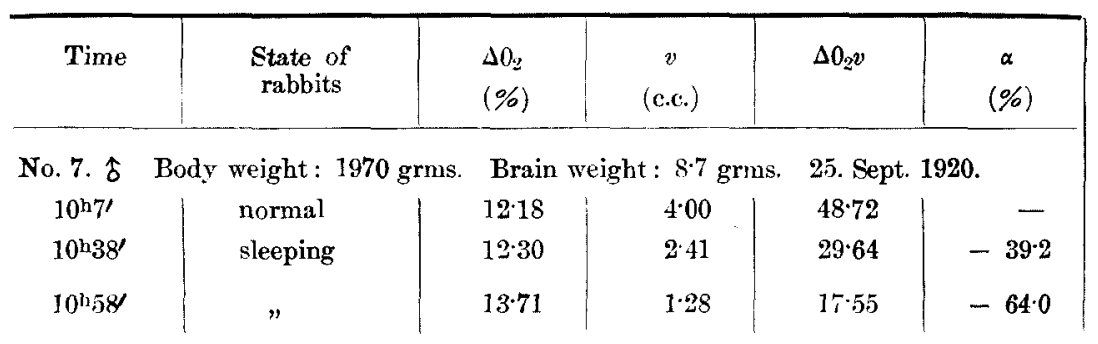

As the tables demoustrate, the influence of chloral hydrate upon the oxygen consumption in the brain was very marked, giving a decrease of $34.6 \%(18 \cdot 8-54 \cdot 1 \%)$ on an average, which is a little inferior to that with ether, chloroform or magnesium. The oxygen consumption decreased always, whereas the blood flow was unchanged (Table XI, A) or increased (XI, B) in most cases and seldom it decreased (Table XI, c). Thus the disturbance of gaseous exchange in the brain caused by chloral hydrate is due to its direct action, and is not a secondary result produced by the change in the blood flow.

As to the action of chloral hydrate on the cerebral vessels, Roy and Sherrington ${ }^{1}$ have pointed out that chloral produced marked contraction of the cerebral vessels not accompanied by any corresponding fall in the arterial pressure and this cerebral anaemia was proceeded by a temporary congestion lasting two or three minutes, whilst Wiechow-

1) Roy and Sherrington, l.c. 
XI, в.

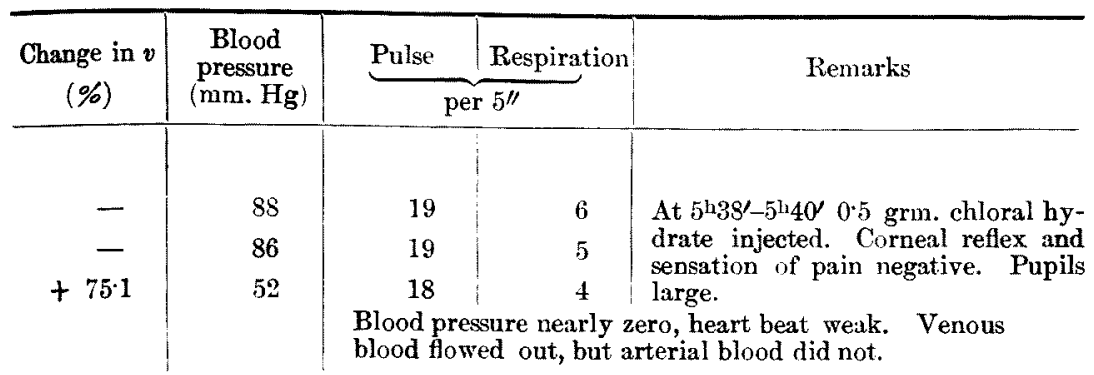

XI, c.

\begin{tabular}{|c|c|c|c|c|}
\hline $\begin{array}{c}\text { Change in } v \\
\text { (\%) }\end{array}$ & $\begin{array}{c}\text { Blood } \\
\text { pressure } \\
(\mathrm{mm} . \mathrm{Hg})\end{array}$ & $\underbrace{\text { Pulse }}_{1}$ & $\frac{\text { Respiration }}{5^{\prime \prime}}$ & Remarks \\
\hline - & 86 & 24 & 12 & At $10 \mathrm{~h} 2 \overline{0}^{\prime}-10^{\mathrm{ln} 28} \quad 0: 5 \mathrm{grm}$. chloral \\
\hline$-39 \cdot 7$ & 64 & 24 & 5 & $\begin{array}{l}\text { Corneal reflex abolished. Sensation } \\
\text { of pain abolished. Pupils normal. }\end{array}$ \\
\hline$-68 \cdot 0$ & 44 & 26 & 10 & Corneal reflex negative. \\
\hline
\end{tabular}

skit) and Berezin ${ }^{2)}$ innounced dilation of the cerebral vessels following the fall of general arterial pressure. In my experiments, already during the injection of chloral the corneal reflex disappeared, the bulbus projected and the pupils contracted, and were soon afterwards enormously enlarged. In most cases, the arterial pressure began to descend in ten minutes after the injection and the respiratory rate was reduced. About twenty minutes after the injection the corneal reflex slightly reappeared, while the blood pressure showed no tendency to restore. The blood flow through the brain was unchanged or increased in most cases during the loss of corneal reflex and the lowering of blood pressure, whereas on the contrary it decreased about the time that the corneal reflex reappeared. Thus in the earlier stage the cerebral vessels dilated and in the later stage the blood flow decreased following the descent of the blood pressure.

1) Wiechowski, Arch. f. exp. Pathol. u. Pharmakol., 1902, 48, 376.

2) Berezin, l.c. 
As a general rule raised activity of the organs followed by an increase of energy exchange is connected with the dilation of the local vessels and the increase in mass movement of blood through the organs, and during the rest of the organ function which accompanies the decrease of energy exchange the blood flow is reduced. Here is found an exception in the action of chloral hydrate and chloroform, in which the blood flow through the brain is augmented, whereas the organ activity together with the oxidation is reduced, an evidence that the rest of the organ function is not always connected with the decline of blood flow. The marked decrease in oxygen consumption of the brain in spite of the increased blood flow suggests that the depressant effect of the drug on the central nervous organ is powerful.

\section{Paraldehyd.}

As a hypnotic which does not contain halogen, paraldehyd was used. A suspension in Ringer's solution in the ratio of $2 \%$ was hypodermically injected into the rabbit by $5-7 \frac{1}{2}$ c.c. per kilo of body

Effect of

TABLE

\begin{tabular}{c|c|c|c|c|c|}
\hline Time & $\begin{array}{c}\text { State of } \\
\text { rabbits }\end{array}$ & $\begin{array}{c}\Delta 0_{2} \\
(\%)\end{array}$ & $\begin{array}{c}v \\
(c . c)\end{array}$ & $\Delta 0_{2} v$ & $\alpha$ \\
\end{tabular}

No. 1. \& Body weight: 2100 grms. Brain weight: $9 \cdot 4$ grms. 26. Oct. 1920.

\begin{tabular}{l|c|c|c|c|r}
$3^{\mathrm{h}} 17^{\prime}$ & normal & 5.19 & 1.45 & 7.53 & - \\
$3^{\mathrm{h}} 42^{\prime}$ & sleeping & 4.67 & 0.87 & 4.06 & -46.6 \\
$3^{\mathrm{h}} 59^{\prime}$ & $" 1$ & 4.30 & 0.55 & 2.37 & -68.5
\end{tabular}

No. 2. 우 Body weight: 2800 grms. Brain weight : $9 \cdot 5$ grms. 28. Oct. 1920 .

\begin{tabular}{l|c|c|c|c|r}
$2^{\mathrm{h}} 0^{\prime}$ & normal & 1.11 & $11 \cdot 40$ & 12.65 & - \\
$2^{\mathrm{h} 27^{\prime}}$ & sleeping & 4.04 & 1.68 & 6.79 & -46.4 \\
$2^{\mathrm{h}} 47^{\prime}$ & $" \prime$ & 3.78 & 0.87 & 3.29 & $-73 \cdot 9$
\end{tabular}

No. 3. ㅇ Body weight: 2000 grms. Brain weight: 8.6 grms, 29. Oct. 1920 .

\begin{tabular}{l|c|r|r|r|r|}
$3^{\mathrm{h}} 11^{\prime}$ & normal & 1.30 & 7.50 & 9.75 & - \\
$3 \mathrm{~h} 28^{\prime}$ & sleeping & 10.99 & 0.59 & 6.48 & -33.5 \\
$3^{\mathrm{h}} \tilde{\mathrm{j}} 0^{\prime}$ & $"$ & 4.93 & 0.22 & 1.08 & -88.9
\end{tabular}


weight. The blood was collected 15-20 minutes after the injection and again 20 minutes later. The corneal reflex was lost within 10 minutes after the injection. There was no change in the arterial pressure or the heart beat, only the respiration was somewhat deeper and less frequent. The pupils always preserved their usual size. The blood flow through the brain was remarkably reduced while the arterial pressure was not altered or even slightly ascended, pointing out that the cerebral vessels distinctly contracted.

The oxygen consumption showed a decrease, the rate of which was greater than in the case of chloral hydrate, but was overcome by the rate of reduction in the blood flow. It might here be mentioned that in the most cases of chloral hydrate the blood flow did not decrease but increased. In the case, where the blood sample was collected 40 minutes after the injection, the decrease in the blood flow was still greater and also the oxygen consumption more disturbed. The effect of paraldehyd upon oxygen consumption might be partly dependent on the change in the brain circulation, as will be discussed later.

\section{Paraldehyd.}

XIr.

\begin{tabular}{|c|c|c|c|c|}
\hline $\begin{array}{l}\text { Change in } v \\
\text { (\%) }\end{array}$ & $\begin{array}{c}\text { Blood } \\
\text { pressure } \\
\text { (mm. Hg) }\end{array}$ & $\underbrace{\text { Pulse }}$ & $\frac{\text { Respiration }}{5^{\prime \prime}}$ & Remarks \\
\hline - & 100 & 20 & 4 & At $3^{\mathrm{h}} 23^{\prime} 4^{\circ} 0$ grms. paraldehyd in- \\
\hline$-40^{\circ} 0$ & 96 & 22 & 5 & $\begin{array}{l}\text { Corneal reflex abolished. Pupils } \\
\text { normal. Sensation of pain provoked. }\end{array}$ \\
\hline$-62 \cdot 1$ & 100 & 20 & 5 & No corneal reflex. Pupils normal. \\
\hline$-85 \cdot 3$ & $\begin{array}{l}104 \\
110\end{array}$ & 20 & $\begin{array}{r}10 \\
4\end{array}$ & $\begin{array}{l}\text { At } 2^{\mathrm{h} 5} 3.0 \mathrm{grms} \text {. paraldehyd injected. } \\
\text { Corneal reflex abolished. Sensation } \\
\text { of pain positive. }\end{array}$ \\
\hline-924 & 82 & 25 & 4 & $\begin{array}{l}\text { No corneal reflex. Sensation of pain } \\
\text { abolished. }\end{array}$ \\
\hline- & 92 & 18 & 11 & $\begin{array}{l}\text { At } 3^{\mathrm{h}} 15^{\prime} \quad 30 \text { grms. paraldehyd in- } \\
\text { jected. }\end{array}$ \\
\hline$-92 \cdot 1$ & 90 & 18 & 5 & $\begin{array}{l}\text { Corneal reflex abolished. } \\
\text { No corneal reflex. Sensation of pain }\end{array}$ \\
\hline$-97 \cdot 1$ & 86 & 18 & 5 & positive. \\
\hline
\end{tabular}




\section{Hypnotics of Urea Derivatives.}

(i) Urethane.

Warburg') observed, that phenyl urethane in a certain concentration, which restrained segmentation of fructified eggs of echinoidea, produced an insignificant depression of oxygen consumption, but Winterstein ${ }^{2}$ has reported that during the anaesthesia with ethyl urethane the oxygen consumption of the spinal cord of frogs was exceedingly reduced. Now, the following experiments were undertaken to confirm what influence it had on the brain. $7 \frac{1}{2}$ to 10 c.c. of $25 \%$ solution of ethyl urethane in Ringer per kilo of body weight were injected hypodermically into the rabbits. The corneal reflex disappeared in 15 minutes, the arterial blood pressure was at first unchanged, but later descended, the respiratory rate was somewhat reduced, but the heart rate slightly increased.

The oxygen consumption showed a decrease of $40.4 \%$ on an

Effect of

TABLE

\begin{tabular}{c|c|c|c|c|c|}
\hline Time & $\begin{array}{c}\text { State of } \\
\text { rabbits }\end{array}$ & $\begin{array}{c}\Delta 0_{2} \\
(\%)\end{array}$ & $\begin{array}{c}v \\
\text { (c.c.) }\end{array}$ & $\Delta 0_{y} v$ & $\begin{array}{c}\alpha \\
(\%)\end{array}$ \\
\hline
\end{tabular}

No. 2. 우 Body weight: $2250 \mathrm{grm}$. Brain weight: 8.0 grms. 19. Oct. 1920.

\begin{tabular}{l|c|c|c|c|c}
$2^{\mathrm{h}} 25^{\prime}$ & normal & 6.74 & 1.13 & $7 \cdot 62$ & - \\
$2^{\mathrm{h}} 58^{\prime}$ & sleeping & 6.93 & 1.05 & $7 \cdot 28$ & -4.5 \\
$3^{\mathrm{h}} 17^{\prime}$ & $\ldots$ & 7.78 & 0.90 & 7.00 & -8.1
\end{tabular}

No. 3. \& Body wight: 1850 grms. Brain weight: 8.5 grms. 20. Oct. 1920.

\begin{tabular}{l|c|r|r|r|r}
$10^{\mathrm{h}} 188^{\prime}$ & normal & $8 \cdot 71$ & $5 \cdot 27$ & $45 \cdot 90$ & - \\
$11^{\mathrm{h}} 0^{\prime}$ & sleeping & $9 \cdot 45$ & $1 \cdot 20$ & $11 \cdot 34$ & $-75 \cdot 3$ \\
$11^{\mathrm{h}} 18^{\prime}$ & $" \prime$ & $10 \cdot 19$ & 1.08 & $11 \cdot 01$ & -76.0
\end{tabular}

No. 4. \& Body weight: 2200 grms. Brain weight: 8.0 grnss. 24. Oct. 1920.

\begin{tabular}{c|c|c|c|c|c}
$10^{\mathrm{h}} 19^{\prime}$ & $\begin{array}{c}\text { not sleep } \\
\text { sleeping }\end{array}$ & 11.00 & 2.08 & 22.88 & - \\
$10^{\mathrm{h}} 50^{\prime}$ & 10.57 & 0.97 & 10.25 & -55.2 \\
$11^{\mathrm{h} g}$ & $\ldots$ & 12.63 & 0.45 & 5.68 & -75.2
\end{tabular}

No. 5. $\delta$ Body weight : 1980 grms. Brain weight: 8.5 grms. 23. Oct. 1920.

\begin{tabular}{l|c|c|c|c|c|}
$1^{\mathrm{h}} 33^{\prime}$ & normal & 2.26 & 5.45 & 12.32 & - \\
$1^{\mathrm{h}} 52$ & sleeping & 4.45 & 2.03 & 9.03 & -26.7 \\
$2^{\mathrm{h}} 12$ &,$"$ & 5.07 & 0.77 & 3.90 & -68.3
\end{tabular}

1) Warburg, l.c.

2) Winterstein, l. c. 
average, a disturbance of oxidation of nearly the same degree as in the case of chloroform and chloral hydrate. There was also a diminution of blood flow through the brain parallel to the reduced gaseous exchange.

It is obvious that here the cerebral vessels inclined to contract slightly, as the cerebral blood flow markedly decreased, while the fall of arterial pressure was inconspicuous and the heart beat unaltered.

(ii) Sodium Veronal. (Medinal).

A 5\% sodium 'veronal Ringer's solution was injected hypodermically to the rabbit by 10 c.c. per kilo of body weight. After 30 minutes tremor and increased excitability of the animal resulted and after 60 minutes paresis of the posterior extremities, but the corneal reflex was still preserved. A moderate dose of the drug caused no effect on the blood pressure, the heart rate or the respiration. But a dosage of 1 grm. per kilo of body weight caused respiratory paralysis and then death, while even in this case the corneal reflex was kept till the last.

\section{Urethane.}

XIII.

\begin{tabular}{|c|c|c|c|c|}
\hline $\begin{array}{l}\text { Change in } v \\
(\%)\end{array}$ & $\begin{array}{c}\text { Blood } \\
\text { pressure } \\
(\mathrm{mm} . \mathrm{Hg})\end{array}$ & Pulse & $\frac{\text { Respiration }}{5^{\prime \prime}}$ & Remarks \\
\hline- & 96 & 22 & 11 & At $2^{\text {h }} 29^{\prime}$ pulse rate 22, respiration 8 . \\
\hline$-7 \cdot 1$ & 92 & 25 & 5 & At $2 \mathrm{~h} 30^{\prime} 5.0$ grms. urethane injected. \\
\hline-143 & 82 & 25 & 5 & pupils normal. \\
\hline- & 9.5 & 22 & 5 & At $10^{\mathrm{h}} 25^{\prime} 5.0$ grms, urethane injected. \\
\hline$-77 \cdot 2$ & 80 & 24 & 4 & No corneal reflex. \\
\hline$-79 \cdot 5$ & 76 & 23 & 5 & No corneal reflex. \\
\hline- & 82 & 22 & 4 & $\begin{array}{l}\text { At } 10^{\mathrm{h}} 15^{\prime} \text { pulse } 22, \text { respir. } 4 \text {. Blood } \\
\text { pressure } 88 \text {. }\end{array}$ \\
\hline$-53 \cdot 4$ & 66 & 24 & 5 & $\begin{array}{l}\text { At } 10^{\mathrm{b}} 16^{\prime} 375 \mathrm{grms} \text {. urethane injected. } \\
\text { Corneal reflex abolished. }\end{array}$ \\
\hline$-78 \cdot 4$ & 60 & 25 & 5 & Corneal reflex abolished. \\
\hline - & 97 & 20 & 6 & It $1^{\mathrm{b}} 40^{\prime} 3.75$ grms. urethane injected. \\
\hline$-62 \cdot 8$ & 92 & 24 & 4 & Corneal reflex negative. \\
\hline$-85 \cdot 9$ & 78 & 23 & 4 & Corneal reflex negative. \\
\hline
\end{tabular}


The change in the blood flow through the brain was not constant, showing in some cases increase, in other no change, but in other cases decrease. The oxygen consumption was accelerated or unaltered, no matter how the blood flow might be.

Thus the action of veronal on the gaseous exchange and the function of the brain in rabbits can be considered similar to that of mor-

\section{Effect of}

TABLE

\begin{tabular}{c|c|c|c|c|c|}
\hline Time & $\begin{array}{c}\Delta 0_{2} \\
(\%)\end{array}$ & $\begin{array}{c}v \\
(\text { c.c. })\end{array}$ & $\Delta 0_{2} v$ & $\begin{array}{c}\alpha \\
(\%)\end{array}$ & $\begin{array}{c}\text { Change in } v \\
(\%)\end{array}$ \\
\hline
\end{tabular}

No.1. o Body weight: 2000 grms. Brain weight: 977 grms. 3. Nov. 1920.

\begin{tabular}{l|l|l|r|r|r}
$10^{\mathrm{h}} 19^{\prime}$ & 5.93 & $1 \cdot 21$ & $7 \cdot 18$ & - \\
$10^{\mathrm{h}} 55^{\prime}$ & $5 \cdot 93$ & 1.63 & $11 \cdot 30$ & $+57 \cdot 4$ & $+\mathbf{3 3 \cdot 9}$ \\
$11^{\mathrm{h}} 20^{\prime}$ & $6 \cdot 74$ & 1.83 & $12 \cdot 33$ & -
\end{tabular}

No. 2. 우 Body weight: 2250 grms. Brain weight: $9 \cdot 0$ grms. 3. Nov. 1920 .

\begin{tabular}{l|l|l|l|l|r}
$4^{\mathrm{h}} 37^{\prime}$ & 2.03 & $8 \cdot 00$ & 16.24 & \\
$5^{\mathrm{h}} 15^{\prime}$ & 8.01 & 272 & $21 \cdot 79$ & $+34 \cdot 2$ & +660 \\
$5^{\mathrm{h}} 39^{\prime}$ & 9.01 & $2 \cdot 10$ & 18.92 & - & -
\end{tabular}

No. 3. 合 Body weight: 2180 grms. Brain weight: 8.6 grms. 4. Nov. 1920.

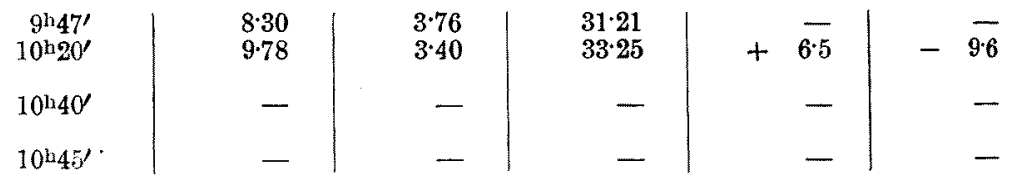

No. 5. 우 Body weight : 2200 grms. Brain weight: 9.0 grms. 8. Nov. 1920 .

\begin{tabular}{l|l|l|l|l|r|}
$10^{\mathrm{h}} 43^{\prime}$ & 1.90 & 2.68 & 5.09 & - & - \\
$11^{\mathrm{l}} 23^{\prime}$ & 5.74 & 0.91 & 5.22 & +2.2 & -66.0 \\
$11^{\mathrm{h}} 50^{\prime}$ & 4.95 & 0.86 & 4.26 & -16.3 & -67.9
\end{tabular}

No. 8, 우 Body weight: $2300 \mathrm{grm}$. 4. Nov. 1920 .
$10^{\mathrm{h}} 15^{\prime}$
1.2 grms. medinal hypodermically injected.
$10^{\mathrm{h}} 45^{\prime}$
The rabbit became somewhat vigourless.
$11^{\text {h }}$
$12^{\text {h }}$
The animal entirely vigourless in a side position, corneal reflex pre-
$12^{1} 40^{\prime}$
Corneal reflex promptly provoked.
The aniwal died. Corneal reflex positive till the last.

No.9. \& Body weight: 1900 grms. 6. Nov. 1920.
$10^{\text {has' }}$
$0.375 \mathrm{grms}$. medinal hypodernically injected.
$11^{\mathrm{h}} 20^{\prime}$
Slight paresis of the hind legs, positive corneal reflex.
$5^{\text {h }}$ P.M. Corneal reflex prompt and the rabbit vigorous. 
phine. Namely, in both cases, where the corneal reflex was not lost, but the paresis of extremities was shown, there was no change in the oxygen consumption or sometimes even an increase in it. Both led to the respiratory paralysis, only the depressant effect of morphine on the central respiratory mechanism being much greater.

\section{Veronal.}

XIV.

\begin{tabular}{|c|c|c|c|}
\hline $\begin{array}{l}\text { Blood } \\
\text { pressure } \\
(\mathrm{mm} . \mathrm{Hg})\end{array}$ & Pulse & $\frac{\text { Respiration }}{5^{\prime \prime}}$ & Remarks \\
\hline $\begin{array}{r}108 \\
100 \\
84\end{array}$ & $\begin{array}{l}23 \\
23 \\
23\end{array}$ & $\begin{array}{l}5 \\
4 \\
3\end{array}$ & $\begin{array}{l}\text { At } 10^{\mathrm{h}} 30 \mathrm{1} \cdot 0 \text { grm. medinal injected. } \\
\text { Corneal reflex positive. } \\
\text { Corneal reflex positive. Pupils large. }\end{array}$ \\
\hline $\begin{array}{l}112 \\
114 \\
112\end{array}$ & $\begin{array}{l}22 \\
22 \\
22\end{array}$ & $\begin{array}{l}3 \\
\mathbf{3} \\
\mathbf{3}\end{array}$ & $\begin{array}{l}\text { At } 4^{\mathrm{l}} 52 \mathrm{2} \\
0.75 \\
\text { injected. Corneal reflex postive. } \\
\text { Corneal reflex positive. Pupils normal. }\end{array}$ \\
\hline $\begin{array}{r}104 \\
90 \\
-\end{array}$ & $\begin{array}{l}18 \\
18 \\
19\end{array}$ & $\begin{array}{l}3 \\
3 \\
7\end{array}$ & $\begin{array}{l}\text { At } 9^{\mathrm{h}} \text { ว } 0 \text { } 2: 0 \text { grms. medinal injected. } \\
\text { Corneal reflex and sensation of pain pro- } \\
\text { voked. } \\
\text { Corneal reflex positive. }\end{array}$ \\
\hline 40 & irregular & - & At $10^{\mathrm{b}} 50^{\prime}$ the rabbit died. \\
\hline $\begin{array}{l}116 \\
106\end{array}$ & $\begin{array}{l}20 \\
20\end{array}$ & $\begin{array}{l}8 \\
4\end{array}$ & $\begin{array}{l}\text { At } 10^{\mathrm{h}} 48^{\prime} 0.5 \mathrm{grm} \text {. medinal injected. } \\
\text { Corneal reflex and sensation of pain positive. }\end{array}$ \\
\hline 96 & 22 & 4 & Corneal reflex positive. \\
\hline
\end{tabular}

Berved, heart beat normal, respiratory rate decreased. 


\section{(iii) Sodium Luninal.}

A $2.5 \%$ sodium Jumiual $R$ inger's solution was injected hypodermically into rabbits by 4 c.c. per kilo of body weight. After 20-30 minutes the corneal reflex always disappeared, the blood pressure and respiratory rate were lowered, while no change in the heart rate and pupils occurred; neither tremor nor convulsion were observed.

There was clearly demonstrated in the brain a decrease in the oxygen consumption and blood flow, which was accompanied by the fall of arterial pressure.

Effect of

Table

\begin{tabular}{c|c|c|c|c|c|}
\hline Tine & $\begin{array}{c}\text { State of } \\
\text { rabbits }\end{array}$ & $\begin{array}{c}\Delta 0_{2} \\
(\%)\end{array}$ & $\begin{array}{c}v \\
(\text { c.c. })\end{array}$ & $\Delta 0_{2} v$ & $\begin{array}{c}\alpha \\
(\%)\end{array}$ \\
\hline
\end{tabular}

No. 1. 우 Body weight: 2015 grms. Brain weight: 9.0 grms. 10. Nov. 1920 .

\begin{tabular}{l|c|c|c|c|r}
$3^{h} 35^{\prime}$ & normal & $3 \cdot 70$ & $4 \cdot 70$ & $17 \cdot 39$ & - \\
$4^{\mathrm{h}} 15^{\prime}$ & sleeping & $6 \cdot 74$ & $2 \cdot 01$ & $13 \cdot 55$ & $-22 \cdot 1$ \\
$4^{\mathrm{l}} 37^{\prime}$ & $\cdots$ & $7 \cdot 45$ & 1.00 & $7 \cdot 45$ & -
\end{tabular}

No.2. $\hat{\circ}$ Body weight: 1780 grms. Brain weight: 8.0 grms. 12. Nov. 1920.

\begin{tabular}{c|c}
$4^{\mathrm{h}} 15^{\prime}$ & normal \\
$4^{\mathrm{h}} 53^{\prime}$ & sleeping \\
$5^{\mathrm{h}} 20^{\prime}$ & $"$
\end{tabular}

\begin{tabular}{l|l|}
3.89 & 3.72 \\
3.34 & 1.29 \\
1.71 & 0.99
\end{tabular}
$14 \cdot 47$
4.31
$-70 \cdot 2$

No.3. 合 Body weight: 2200 grms. Brain weight: 8.8 grms. 13. Nov. 1920 .

\begin{tabular}{l|c|}
$10^{\mathrm{h}} 38^{\prime}$ & normal \\
$11^{\mathrm{h}} 17^{\prime}$ & sleeping \\
$11^{\mathrm{h}} 40^{\prime}$ &,$"$
\end{tabular}

\begin{tabular}{r|r}
4.82 & 5.78 \\
10.85 & 1.73 \\
10.93 & 1.53
\end{tabular}

$27 \cdot 86$
$18 \cdot 77$
$16 \cdot 72$

$-326$

Now luminal differs chemically from veronal only in one point that one of two ethyl groups is replaced by a phenyl group. But whilst a large dose of sodium veronal given to the rabbits did not abolish the corneal reflex, but produced tremor, sodium luminal by only $0.1 \mathrm{grm}$. per kilo of body weight made the animal sleep and lose its corneal reflex; it reduced moreover the blood pressure and the respiratory rate. 
Thus luminal as a hypnotic is superior in every respect to veronal. According to Impen $\mathrm{s}^{1)}$, the action of veronal is composed of a central depressive component and another latent component, the latter having a stimulating and convulsive tendency. This evidence was demonstrated also in the gaseous exchange of the brain, which was augmented by administration of veronal even in the case where the blood flow decreased. And really the rabbit showed tremor and convulsion on its injection. By addition of a phenyl group this action is lost, whilst the hypnotic action becomes much stronger, and consequently the oxidation in the brain is disturbed much more markedly.

\section{Luminal.}

XV.

\begin{tabular}{|c|c|c|c|c|}
\hline $\begin{array}{l}\text { Change in } v \\
\text { (\%) }\end{array}$ & $\begin{array}{c}\text { Blood } \\
\text { pressure } \\
\text { (mm. Hg) }\end{array}$ & $\underbrace{\text { Pulse }}_{1}$ & $\frac{\text { Respiration }}{r 5^{\prime \prime}}$ & Remarks \\
\hline 一 & 90 & 20 & 12 & At $3^{\mathrm{h}} 37^{\prime} 0.2 \mathrm{grm}$. sodium luminal in- \\
\hline$-57 \cdot 2$ & 72 & 20 & 5 & Jecten. \\
\hline- & 64 & 20 & 5 & $\begin{array}{l}\text { No corneal reflex. Sensation of pain } \\
\text { scarcely demonstrable. }\end{array}$ \\
\hline - & 88 & 19 & 10 & 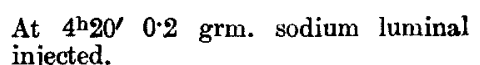 \\
\hline$-65 \cdot 3$ & 82 & 20 & 3 & $\begin{array}{l}\text { Corneal reflex abolished. Sensation of } \\
\text { pain demonstrable. Pupils normal. }\end{array}$ \\
\hline - & 76 & 20 & 3 & $\begin{array}{l}\text { No corneal reflex. Sensation of pain } \\
\text { scarcely demonstrable. Pupils normal. }\end{array}$ \\
\hline- & 104 & 19 & 6 & $\begin{array}{l}\text { At } 10^{\mathrm{l}} 47^{\prime} 0.2 \mathrm{grm} \text {. sodium luminal } \\
\text { injected. }\end{array}$ \\
\hline$-70 \cdot 1$ & 90 & 20 & 3 & $\begin{array}{l}\text { Corneal reflex abolished. Sensation of } \\
\text { pain pusitive. }\end{array}$ \\
\hline- & 70 & 20 & 3 & $\begin{array}{l}\text { No sensation of pain. No corneal re- } \\
\text { flex. Pupils normal. }\end{array}$ \\
\hline
\end{tabular}

\section{Arcohol.}

The action of alcohol, especially depressing and paralysing the central nervous system, depends to some extent on its lipoid-dissolving

1) Impens, Deutsch. med. Wochenschr., 1912,945. 
power like that of inhalation narcotics and hypnotics. But a paradoxical phenomenon between the narcotic effect of alcohol and gaseous exchange in the brain has been reported by Winterstein ${ }^{1)}$ who observed that in spite of completely suspended reflex excitability of the spinal cord of the frog with alcohol, the oxygen consumption showed an increase. And concerning the action of alcohol on the cerebral vessels, Roy and Sherrington ${ }^{2)}$ demonstrated the expansion of the brain volume, Bayliss and $\mathrm{Hill}^{3)}$ the lowering of the cerebral venous blood pressure following the arterial fall ; on the other hand Wiechowskis) observed no effect with a large dose (40 c.c. of $10 \%$ alcohol on rabbits),

Effect of

TABLE

\begin{tabular}{c|c|c|c|c|}
\hline Time & $\Delta 0_{2}$ & $v$ & $\Delta 0_{2} v$ & $\alpha$ \\
$(\%)$ & $($ e.c. $)$ & & $(\%)$ \\
\hline
\end{tabular}

No. 3. 우 Body weight: 2640 grms. Brain weight: $7 \cdot 2$ grms. 19. Nov. 1920 .

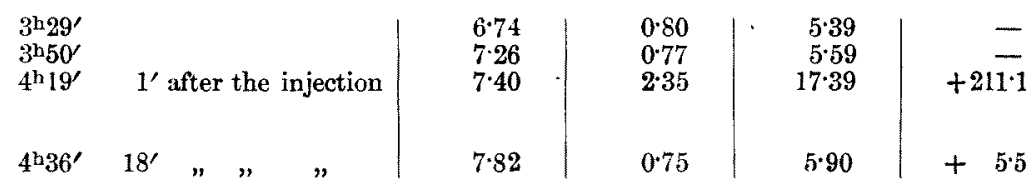

No. 4. ㅇ Body weight: 2150 grms. Brain weight: $9 \cdot 2$ grms. 20. Nov. 1920 .

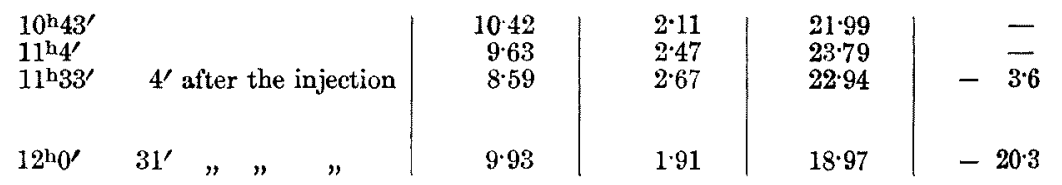

No. 12. 우 Body weight: 2280 grms. Brain weight: $9 * 1$ grms. 1. Dec. 1920 .

\begin{tabular}{ll|l|l|l|l}
$10^{\mathrm{b}} 17^{\prime}$ & & $6 \cdot 74$ & $2 \cdot 33$ & $15 \cdot 70$ & \\
$10^{\mathrm{h}} 588^{\prime \prime}$ & $13^{\prime}$ after the injection & $9 \cdot 67$ & $2 \cdot 09$ & $20 \cdot 21$ & $+28 \cdot 7$
\end{tabular}

No. 13. o Body weight: 1860 grms. Brain weight: 8.0 grms. 1. Dec. 1920.

\begin{tabular}{|c|c|c|c|c|c|}
\hline $2^{\mathrm{h}} 28^{\prime}$ & & $4 \cdot 70$ & 5.95 & $27 \cdot 97$ & - \\
\hline $\begin{array}{l}2^{\mathrm{n}} 533_{2}^{\prime} \\
3^{\mathrm{b}} 19^{\prime}\end{array}$ & $\begin{array}{l}22^{\prime} \text { after the injection } \\
2 y^{\prime \prime}\end{array}$ & $\begin{array}{l}7.08 \\
7.82\end{array}$ & $\begin{array}{l}7.58 \\
4.00\end{array}$ & $\begin{array}{l}53.67 \\
31.28\end{array}$ & $\begin{array}{l}+91.8 \\
-11.9\end{array}$ \\
\hline
\end{tabular}

1) Winterstein, l, c.

2) Roy and sherrington, l. c.

3) Bayliss and Hill, l.c.

4) Wiechowski, l. c. 
while later $\mathrm{We}$ e e $\mathrm{r}^{1)}$ announced that he could show an active dilation of the cerebral vessels with a smaller dose than that used by Wiech ow ski.

In my present investigation on the action of ethyl alcohol upon the gaseons metabolism and blood circulation in the brain various doses of alcohol were used : varying from 1 to 10 c.c. of $25 \%$ solution (or 5 c.c. of $50 \%$ solution) per kilo of body weight. The ethyl alcohol was injected into the external jugular vein of rabbits and the blood samples were taken at several intervals, such as 1-2-3-4-5-10-20-30-50 minutes after the injection. The data are as below :

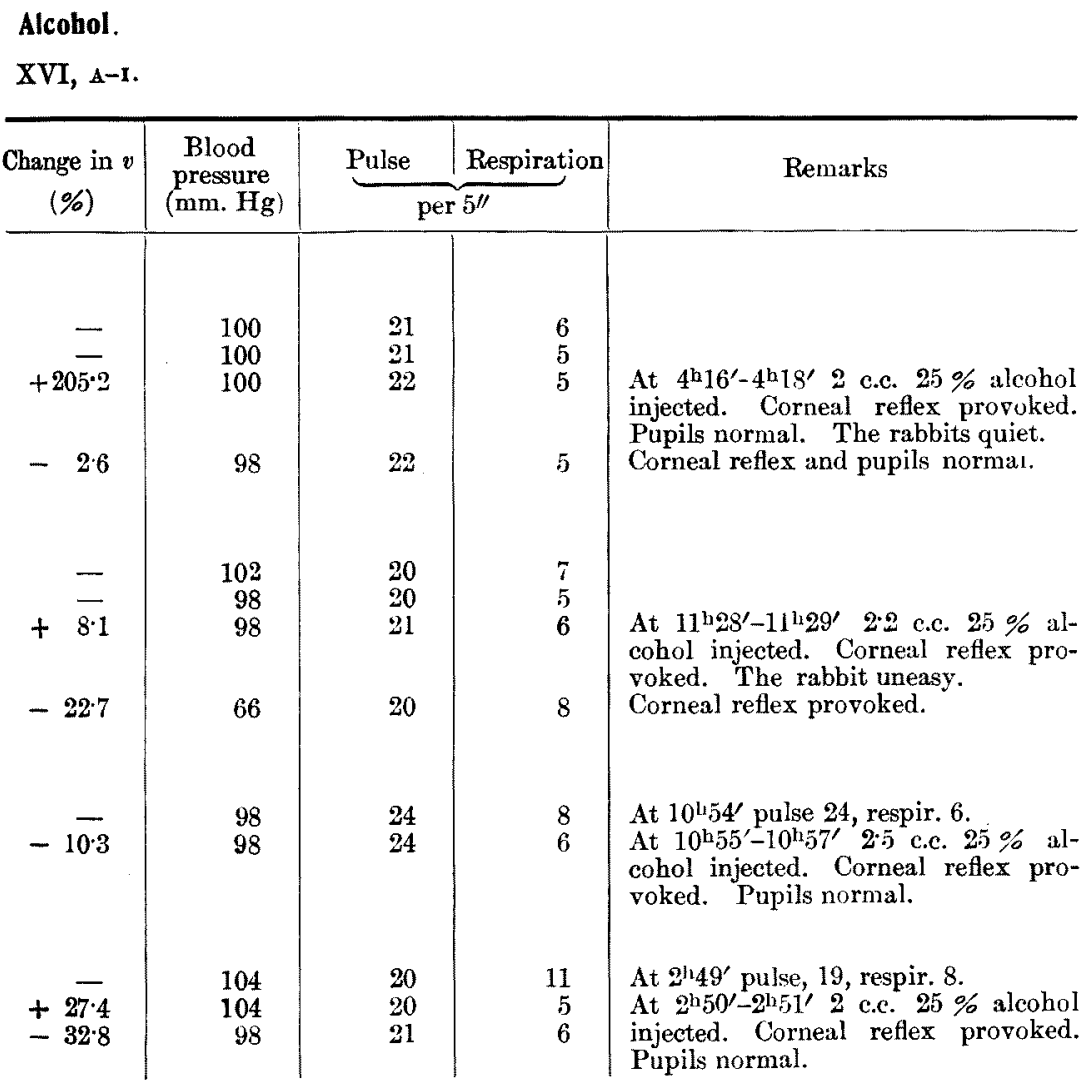

1) Weber, Arch. f. ( Anatom. u.) Physiol., 1909, 348. 
TABLE

\begin{tabular}{|c|c|c|c|c|}
\hline Time & \begin{tabular}{c|c}
$\Delta 0_{2}$ \\
$(\%)$
\end{tabular} & $\begin{array}{c}v \\
(\text { c.c. })\end{array}$ & $\Delta 0_{2} v$ & $\begin{array}{c}\alpha \\
(\%)\end{array}$ \\
\hline
\end{tabular}

N. 9. 우 Body weight: 2470 grm. Brain weight: 9.5 grms. 26. Nov. 1920 .

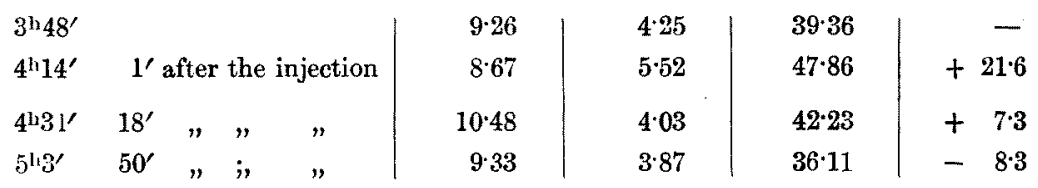

No. 11. o Body weight: 2100 grms. Brain weight 9.5 grms. 30. Nov. 1920 .

\begin{tabular}{|c|c|c|c|c|c|c|c|c|}
\hline $3^{\prime \prime} 2^{\prime}$ & & & & & $10 \cdot 37$ & $3 \cdot 17$ & $32 \cdot 87$ & - \\
\hline $3^{\ln } 26^{\prime}$ & & fter & the & jection & $9 \cdot 18$ & $4 \cdot 64$ & 42.60 & +296 \\
\hline $3^{h} 52^{\prime}$ & $27^{\prime}$ & $n$ & $"$ & $"$ & 9.82 & $2 \cdot 39$ & $23 \cdot 47$ & -28.5 \\
\hline $4^{h} 13^{\prime}$ & $48^{\prime}$ & , & $"$ & $n$ & 7.04 & $2 \cdot 38$ & 16.76 & \\
\hline
\end{tabular}

No. 5. 우 Body weight: 2620 grms. Brain weight: 10.2 grms. 20. Nov. 1920 .

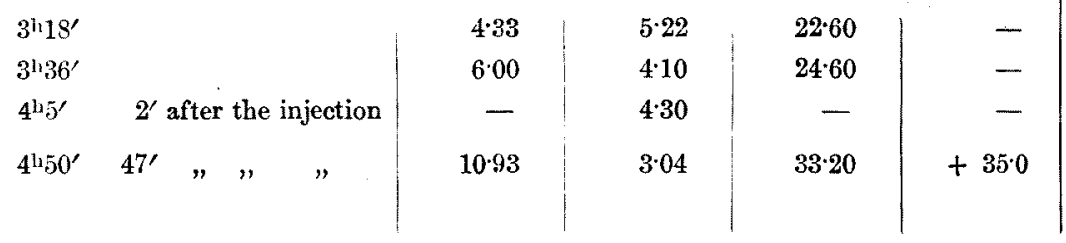

TABLE

\begin{tabular}{|c|c|c|c|c|}
\hline Time & $\begin{array}{c}\Delta 0_{2} \\
(\%)\end{array}$ & $\begin{array}{c}v \\
(\text { c.c. })\end{array}$ & $\Delta 0_{2} v$ & $\begin{array}{c}\alpha \\
(\%)\end{array}$ \\
\hline
\end{tabular}

No. 2. S Body weight: 2000 grms. Brain weight: 9.5 grms. 18. Nov. 1920.

\begin{tabular}{ll|l|l|r|r}
$10^{\mathrm{h}} 11^{\prime}$ & & 7.00 & 3.87 & 27.09 & - \\
$10 \mathrm{~h} 40^{\prime}$ & $5^{\prime}$ after the injection & $7 \cdot 41$ & 1.58 & 11.71 & -56.8 \\
$10 \mathrm{~h} 58^{\prime}$ & $23^{\prime}, ", \quad$, & 5.19 & 1.64 & 8.51 & -68.6
\end{tabular}

No. 1. 合 Body weight: 2030 grms. Brain weight: 9*5 grms. 17. Nov. 1920.

\begin{tabular}{|c|c|c|c|c|c|}
\hline $4 \mathrm{~h} 12^{\prime}$ & & $3 \cdot 63$ & $5 \cdot 33$ & $19 \cdot 35$ & - \\
\hline $4 h 44^{\prime}$ & $S^{\prime}$ after the injection & $8 \cdot 00$ & $2 \cdot 36$ & $18 \cdot 88$ & -24 \\
\hline $5 n 8^{\prime}$ & $32^{\prime}, "$, & $8 \cdot 15$ & 1.98 & $16 \cdot 14$ & -166 \\
\hline
\end{tabular}


XVI, A-2.

\begin{tabular}{|c|c|c|c|c|}
\hline $\begin{array}{c}\text { Change in } v \\
(\%)\end{array}$ & $\begin{array}{l}\text { Blood } \\
\text { pressure } \\
(\text { min. } \mathrm{Hg})\end{array}$ & $\underbrace{\text { Pulse }}$ & $\frac{\text { Respiration }}{5^{\prime \prime}}$ & Remarks \\
\hline- & 98 & 19 & 7 & At $4^{\mathrm{h}} 11^{\prime}-4^{\mathrm{h}} 13^{\prime} 12$ c.c. $25 \%$ alcohol \\
\hline$+29 \cdot 9$ & 98 & 21 & 5 & $\begin{array}{l}\text { Corneal reflex scarcely provoked. Pu- } \\
\text { pils somewhat large. }\end{array}$ \\
\hline$-5 \cdot 2$ & 98 & 21 & 5 & Corneal reflex weakened. Pupils \\
\hline-8.9 & 98 & 22 & 5 & \\
\hline 一 & 102 & 25 & 5 & \\
\hline$+46 \cdot 1$ & 100 & 28 & 7 & $\begin{array}{l}\text { At } 3^{\mathrm{h}} 23^{\prime} \text { pulse } 24 \text {, respir. } 5 . \\
\text { At } 3^{\mathrm{h}} 24^{\prime}-3^{\mathrm{h}} 25^{\prime} 11 \text { c.c. } 25 \% \text { alcohol } \\
\text { injected. Corneal reflex abolished. } \\
\text { Pupils large. }\end{array}$ \\
\hline-246 & 100 & 28 & 6 & $\begin{array}{l}\text { At } 3^{\mathrm{h}} 30^{\prime} \text { corneal reflex reappeared } \\
\text { and bulbus trembled. At } 3^{\mathrm{h}} 40^{\prime} \text { size of } \\
\text { pupils normal. Corneal reflex positive. }\end{array}$ \\
\hline- & 100 & 26 & 6 & Corneal reflex positive. \\
\hline - & 104 & 22 & 6 & \\
\hline & 98 & 22 & 6 & At $3^{\mathrm{h}} 58^{\prime}-4^{\mathrm{h}} 3^{\prime} \quad 21$ c.c. $25 \%$ alcohol \\
\hline$+4 \cdot 9$ & $\mathbf{I} 10$ & 25 & 4 & $\begin{array}{l}\text { injected. Corneal reflex weak. Pupils } \\
\text { somewhat larger. Bulbus trembling. }\end{array}$ \\
\hline-25.9 & 92 & 22 & 6 & $\begin{array}{l}\text { Corneal reflex weak. Pupils normal. } \\
\text { Bulbus trembling. }\end{array}$ \\
\hline
\end{tabular}

XVI, в.

\begin{tabular}{|c|c|c|c|c|}
\hline $\begin{array}{l}\text { Change in } v \\
\qquad(\%)\end{array}$ & $\begin{array}{c}\text { Blood } \\
\text { pressure } \\
\text { (mm. Hg) }\end{array}$ & Pulse & $\frac{\text { Respiration }}{5^{\prime \prime}}$ & Remarks \\
\hline - & 108 & 22 & 7 & At $10^{\mathrm{h}} 33^{\prime}-10^{\mathrm{h}} 35^{\prime} 2$ c.c. $25 \%$ alcohol \\
\hline$-59 \cdot 2$ & 114 & 23 & 7 & injected. Corneal reflex provoked. \\
\hline-57.7 & 106 & 25 & 5 & Corneal reflex provoked. \\
\hline - & 104 & 2 & 12 & At $4^{\mathrm{h}} 32^{\prime}$ pulse 21 , respir. 4 . \\
\hline-55.7 & 98 & 25 & 7 & $\begin{array}{l}\text { At } 4^{\mathrm{h}} 33^{\prime}-4^{\mathrm{l}} 36^{\prime} 10 \text { c.c. } 25 \% \text { alcohol } \\
\text { injected. Corneal reflex provoked. } \\
\text { Pupils normal. }\end{array}$ \\
\hline$-62 \cdot 9$ & 96 & 27 & 7 & Corneal reflex provoked. \\
\hline
\end{tabular}




\begin{tabular}{c|c|c|c|c|}
\hline Time & \begin{tabular}{c|c}
$\Delta 0_{2}$ \\
$(\%)$
\end{tabular} & $\begin{array}{c}v \\
(\text { c.c. })\end{array}$ & $\Delta 0_{2} v$ & $\begin{array}{c}\alpha \\
(\%)\end{array}$ \\
\hline
\end{tabular}

No. 6. 只 Body weight: 2480 grms. Brain weight: $9 \cdot 8$ grms. 23. Nov. 1920.

\begin{tabular}{ll|l|l|l|r}
$11^{\mathrm{b}} 52^{\prime}$ & & 10.48 & 2.96 & 31.02 & - \\
$12^{\mathrm{h}} 7^{\prime}$ & & 11.56 & 2.84 & 32.83 & - \\
$12^{\mathrm{h}} 41^{\prime}$ & $9^{\prime}$ after the injection & 10.52 & 2.22 & 23.35 & -28.9 \\
& & & & & \\
$1^{\mathrm{h}} 3^{\prime}$ & $31^{\prime}, ", \quad, \quad$, & 9.82 & 2.13 & 20.92 & -36.3
\end{tabular}

No. 7. \& Body weight: 2300 grms. Brain weight: $9 \cdot 6$ grms. 24. Nov. 1920.
$\begin{array}{ll}10^{\mathrm{h}} 21^{\prime} & \\ 11^{\mathrm{h}} 0 & 22^{\prime} \\ \end{array}$
$11 \cdot 26$
$7 \cdot 26$

$10 \cdot 43$
$4 \cdot 80$
$117 \cdot 44$
$34 \cdot 85$
$-70 \cdot 3$

No. 8. ㅇ B Body weight: 26.30 grms. Brain weight: 9.4 grms.

25. Nov. 1920.

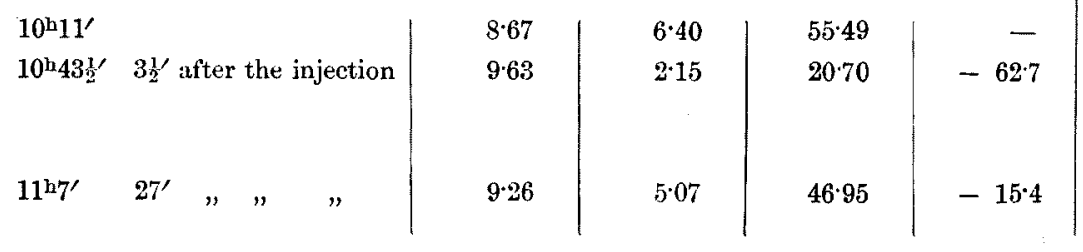

Thus alcohol intravenously injected had little influence on the respiration. By a closage of $0 \cdot 25$ grm. per kilo of body weight no change in the blood pressure, heart rate, corneal reflex, pupils or bulbus occurred; on using 1.25-2.5 grms., the heart rate increased, whilst the blood pressure scarcely changed, the corneal reflex temporarily weakened at the time of the injection, sometimes disappeared, the pupils were mydriatic for a while and frequently tremor of the bulbus well marked. On a dosis of 5 c.c. of $50 \%$ alcohol there was a fall of the blood pressure.

The change in the cerebral blood flow was dependent on the course of time rather than on the dosage. A dosis of $0 \cdot 25-2.5$ grms. per kilo brought about no change in the arterial pressure, but mostly increase in the blood How within 1-4 minutes after the injection. This increase was always demonstrable even with so small an amount of alcohol that the heart rate and the respiration were not altered. It suggests that the cerebral vessels undergo an active dilation for a few minutes after the 
XVI, c

\begin{tabular}{|c|c|c|c|c|}
\hline $\begin{array}{c}\text { Change in } v \\
(\%)\end{array}$ & $\begin{array}{l}\text { Blood } \\
\text { pressure } \\
(\mathrm{mm} . \mathrm{Hg})\end{array}$ & Pulse & $\underbrace{\text { Respiration }}_{\mathbf{r} 5^{\prime \prime}}$ & Remarks \\
\hline- & 104 & 22 & 5 & \\
\hline - & 98 & 22 & 5 & At $12^{\mathrm{L}} 29^{\prime}-12^{\mathrm{h}} 32^{\prime} 12 \cdot 5$ c.e. $50 \%$ alcohol \\
\hline $\begin{array}{l}-21 \cdot 8 \\
-25 \cdot 0\end{array}$ & 98 & 26 & 5 & $\begin{array}{l}\text { Corneal reflex weak. Pupils at first } \\
\text { mall, then normally large. B ulbus } \\
\text { trembling. }\end{array}$ \\
\hline - & 114 & 22 & 6 & \\
\hline$-54 \cdot 0$ & 60 & 27 & 9 & $\begin{array}{l}\text { At } 10^{\mathrm{h}} 25^{\prime}-10^{\mathrm{h}} 28^{\prime} 12 \text { c.c. } 50 \% \text { alcohol } \\
\text { injected. } \\
\text { Corneal reflex weak, } \\
\text { At } 11^{\mathrm{h}} 30^{\prime} \text { the animal died. }\end{array}$ \\
\hline - & 108 & 18 & 10 & At $10^{\mathrm{h}} 36^{\prime}$ pulse 17 , respir. 5 . \\
\hline-20.8 & 60 & 20 & 9 & $\begin{array}{l}\text { At } 10^{\mathrm{b}} 37 /-10^{\mathrm{h}} 40^{\prime} 8 \text { c.c. } 50 \% \text { alcohol } \\
\text { injected. } \\
\text { Corneal reflex abolished. Pupils at } \\
\text { first mydriatic, soon after of normal } \\
\text { size. Bulbus trembling. } \\
\text { Pupils normal. Corneal reflex pre- } \\
\text { served. Bulbus trembling. }\end{array}$ \\
\hline
\end{tabular}

injection (Exp. 3, 4, 9, $11 \& 13$ ). Only in $\operatorname{Exp}$. 8, where 3 c.c. of $50 \%$ alcohol per kilo was injected, the blood flow decreased following the great fall of the blood pressure. Over a few minutes after the injection sometimes both arterial blood pressure and cerebral blood flow showed no change, or the blood flow decreased parallel to the descent of blood pressure, but in other cases the blood flow was reduced without any change in the blood pressure or even with a rise of it (Exp. 1, 2, 5, 6, $11 \& 13)$. Thus, alcohol like ether, chloroform, chloral hydrate etc. causes a preliminary dilation of the cerebral vessels followed by contraction.

Not only the blood flow, but also the oxygen consumption showed variation in the course of time. It increased for a few minutes after the injection so long as the blood flow was increased. On injection of 0.25 grm. per kilo of body weight which caused no loss of corneal reflex the gaseous exchange in the brain was augmented, often in a rate greater than that of the increase in blood flow or accompanied by no 
change in the latter, but sometimes the oxygen consumption was not altered in spite of the increased blood flow (Table XVI, A-1). A dosage larger than 1.25 grms. weakened or abolished the corneal reflex while the oxygen consumption was raised. This increase might be due to the increased blood flow, and the rate of the former was often less than that of the latter (Exp. $9 \& 11)$. In Exp. 8, in which 3 c.c. per kilo was used and the corneal reflex disappeared, the oxygen consumption also was reduced parallel to the decrease in the blood flow, which in turn followed the fall of the blood pressure. Thus the increase in the gaseous exchange in the early stage of alcohol action was greatly influenced by the condition of the blood flow. 'The less the dose injected the greater the increase in the oxygen consumption, and the latter was, the less the dose injected, the less influenced by the blood flow.

These circumstances are similar to those in the prenarcotic stage of ether or chloroform anaesthesia. In the case of chloral hydrate the blood flow through the brain also increased, but the depressant effect on the brain was very marked so that the oxygen consumption decreased exceedingly.

It has been suggested that the stimulating action of alcohol does not find its source in a direct stimulation of the nerve centres, but indirectly in the increased blood flow through the brain. According to my experiments, the gaseous exchange in the first stage of the alcohol action was more influenced by the change in the cerebral blood flow than by the excitability of the animals. This fact is a strong evidence that the stimulant effect of alcohol, which is often clinically observed in the case of depression due to cerebral anaemia, lies in the restoration of the cerebral function and gaseous exchange, owing to the increased blood flow through the brain. In the later stage of alcohol action, when a few minutes had passed after the injection, the oxygen consumption turned to decrease nearly hand in hand with the fall of the blood flow through the brain (Exp. 1, 2, 4, 8 \& 11), but in some cases, where a large amount was injected and the corneal reflex was weakened, the decrease in the oxygen consumption was a little more than that in the blood flow (Exp. $6 \& 7$ ), and in Exp. 3 and 9 the oxygen consumption underwent no change, the corneal reflex and the blood flow being also unaltered. Namely, even in this stage of the alcohol action the oxygen consumption in the brain was influenced by the change in the blood flow; here the reduction in the oxygen consumption was very slight. 
Thus, in my experiments the narcotic effects of alcohol was very imperfect, and in the early stage, while the corneal reflex was or was not lost, the oxygen consumption increased, which is a sequel of the increased blood flow, but on a very large dosage, it was reduced following the decrease in the blood flow, and in the later stage almost all cases showed more or less disturbance of the gaseous exchange in accordance with the fall of the blood flow. Winterstein's' announcement that the oxygen use in the spinal cord is raised during its depression, could not be recognized in my investigations fromi the point of the gaseous metabolism in the brain. Evidence was brought about that alcohol gives rise to the change in the cerebral gaseous exchange through its action on the brain circulation rather than that on the nerve cells.

\section{Some Controlling Experiments.}

In all the above illustrated experiments I used various drugs and stated the relation between gaseous exchange and mass movement of blood through the brain. There was in some cases either an increase or a decrease in the blood flow, while the gaseous exchange underwent the same change or did not so; in other cases both blood flow and oxygen consumption were not altered. Sometimes the change was great while at others it was little. It is now proposed to mention some controlling experiments in which using no drugs, the oxygen consumption, blood flow, blood pressure, heart beat, respiration etc. and the relation to each other should be observed. Below are the data:

1) Winterstein, l. c. 
Control

Table

\begin{tabular}{c|c|c|c|c|c|}
\hline Time & $\begin{array}{c}\text { State of } \\
\text { rabbits }\end{array}$ & $\begin{array}{c}\Delta 0_{2} \\
(\%)\end{array}$ & $\begin{array}{c}v \\
(\text { c.c. })\end{array}$ & $\Delta 0_{2} v$ & $\begin{array}{c}\alpha \\
(\%)\end{array}$ \\
\hline
\end{tabular}

No. 1. 우 Body weight: 1800 grms. Brain weight: $8 \cdot 2$ grms. 30. July 1920 .

\begin{tabular}{l|c|c|c|c|c}
$10^{\text {h1 }} 6^{\prime}$ & normal & $3 \cdot 48$ & $5 \cdot 51$ & $19 \cdot 17$ & $-\overline{17}$ \\
$10^{1 \times 23^{\prime}}$ & $"$ & $9 \cdot 36$ & $1 \cdot 65$ & $15 \cdot 35$ & $-19 \cdot 9$
\end{tabular}

No. 2. 우 Body weight: 2400 grms. Brain weight: $9^{\circ} 0$ grms. 1. Nov. 1920.

\begin{tabular}{l|c|c|c|c|r}
$11^{\mathrm{h}} 5^{\prime}$ & normal & 6.25 & 2.36 & 14.75 & - \\
$11^{\mathrm{h}} 48^{\prime}$ & $"$ & 9.03 & 1.92 & $17 \cdot 34$ & $+17 \cdot 6$ \\
$12^{\mathrm{h}} 5^{\prime}$ & $"$ & 9.93 & 1.66 & 16.48 & +11.1
\end{tabular}

No. 3. 우 Body weight: 2220 grms. Brain weight: $9 \cdot 1$ grms. 2. Nov. 1920 .

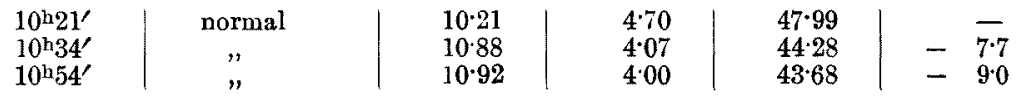

No. 4. ㅇ Body weight: 2600 grms. Brain weight: $9 \cdot 2$ grms. 29. April 1921 .

\begin{tabular}{l|c|r|r|r|r}
$3^{\mathrm{h}} 43^{\prime}$ & normal & $8 \cdot 24$ & $4 \cdot 07$ & $33 \cdot 54$ & - \\
$4^{\mathrm{h}} 42^{\prime}$ & $"$ & $12 \cdot 96$ & 3.00 & $38 \cdot 88$ & $+15 \cdot 6$ \\
$4^{\mathrm{h}} 58^{\prime}$ & $"$, & $11 \cdot 90$ & 3.00 & $35 \cdot 70$ & +6.4
\end{tabular}

No. 5. 우 Body weight: 1950 grms. Brain weight: 8.7 grms. 22. May 1921 .

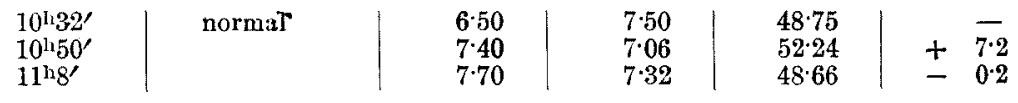

No.6. 우 Body weight: 2730 grms. Brain weight: 8.0 grms. 7. June 1921 .

\begin{tabular}{|c|c|c|c|c|c|}
$7^{\mathrm{l}} \mathrm{4} 3^{\prime}$ & normal & $2 \cdot 10$ & $1 \cdot 70$ & $\mathbf{3} \cdot 57$ & - \\
$7^{\mathrm{l}} 58^{\prime}$ & $1 \cdot 90$ & $1 \cdot 64$ & $3 \cdot 12$ & $-\mathbf{1 2 \cdot 6}$ \\
$8^{\mathrm{l}} 15^{\prime}$ & $"$ & $\mathbf{2} \cdot 10$ & $1 \cdot 30$ & $\mathbf{2} \cdot 73$ & $\mathbf{2 3} \cdot 5$
\end{tabular}

Thus in animals which undergo no action of drugs the cerebral blood flow was reduced following the fall of the blood pressure, but at a rate less than that of the latter; when the latter was unaltered, the former suffered no or only a little (less than $15 \%$ ) change. Every collection of blood samples showed some tendency temporarily to diminish the blood flow. Usually the variation of the blood flow through the brain of less than $15 \%$ scarcely caused any change in the cerebral oxygen consumption, but diminution more than $50 \%$ gave rise to fairly large reduction of the latter; nevertheless the rate of this is far less than that of the former. Variation of the oxygen intake within $15 \%$ may be regarded as normal. 


\section{Experiments.}

XVII.

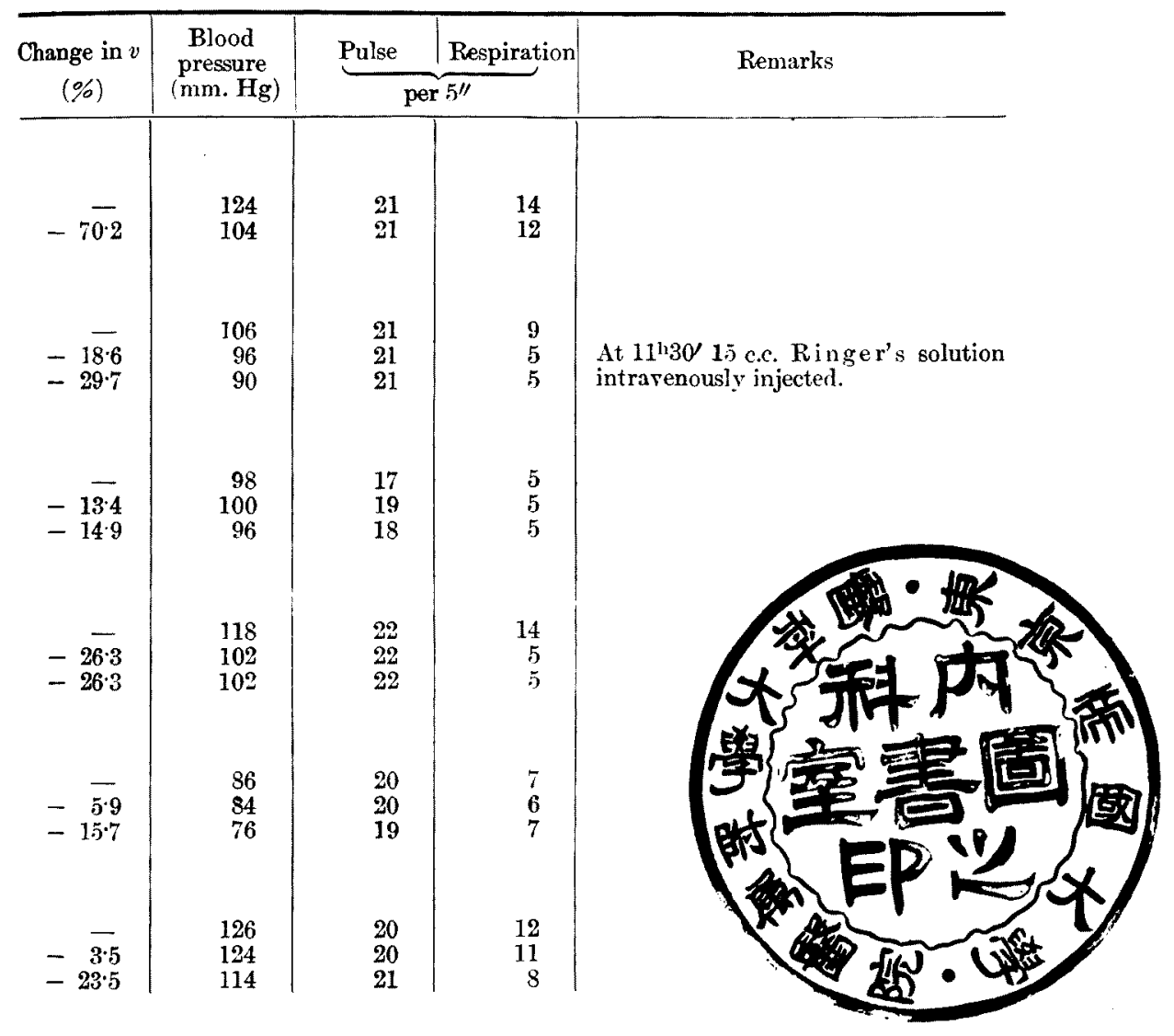

Summary and Discussion.

1. On Nar'cosis and Cerebral Oxygen Consumption. (A Contribution to the Narcosis Theory).

Summarizing the above mentioned results of my experiments, performed with the object of investigating the influence of various narcotics and hypnotics upon the mass movement of blood and upon the oxygen consumption in the brain of rabbits, at the prenarcotic stage of chloroform or ether narcosis and at the early stage of the action of ethyl alcohol injected intravenously, the mass movement of blood through the brain and also the oxygen consumption in it showed an increase, and in the case of 
alcohol and ether, the increase in the oxygen consumption ran almost parallel to that in the blood flow, but in the case of chloroform the former was less than the latter. The rise of gaseous exchange at the prenarcotic stage of chloroform narcosis may be attributed mainly to the change in the blood flow rather than to the augmented excitability of the brain.

Contrary to the report of $\mathrm{W}$ in ters te $\mathrm{in}^{1)}$ that the exciting state in both asphyxia and narcosis was cansed by the inhibition of oxidation, the results of my experiments at that stage showed an increase in the oxygen consumption. But during narcosis and hypnosis caused by all kinds of drugs used, the oxygen consumption in the brain always decreased distinctly, and in nearly all cases, but not always, the blood flow through it was too reduced, whilst every kind of drug showed at each stage its own special feature with regard to the relation of the change in the blood flow and oxygen consumption.

Generally speaking, when the change in blood flow through the brain goes beyond a certain limit, there is an increase or a decrease in the oxygen consumption though no special central effects are developed.

The stronger the action of narcosis or hypnosis the more is the decrease in the oxygen consumption independent on the change in the blood flow, or the oxygen consumption is lowered in a greater rate than the decrease in the blood flow. And in shallow narcosis or in many cases of hypnotics the decrease in the oxygen consumption is either parallel to the fall of the blood flow, or less than it.

Both chloroform and chloral hydrate have the same effect on the blood flow through the brain, namely a primary increase followed by a secondary decrease, while the oxygen consumption decreases notwithstanding the increase in the blood flow. This puts forward the evidence that the disturbance of gaseous exchange in this case is caused not by the changed blood flow but by the direct effects on the brain. In ether or morphine-scopolamine anaesthesia the rate of the decrease in the oxygen consumption is greater than that in the blood flow; here is the decrease in the oxygen consumption attributable partly to the change in the blood flow, but mainly to the effects on the nervous system.

In the rabbit the influence of morphine, pantopon, alcohol or calcium on the gaseous exchange in the brain is insignificant. No change is recognized with scopolamine or veronal. A striking feature is shown

1) Winterste in, Zeitschr. f. allg. Physiol., 1905, 5, 323. 
by the cerebral gas metabolism during the anaesthesia of morphinescopolamine: scopolamine accelerates the inhibitory effect on oxidation of morphine, directly, not by the secondary way of changing the brain circulation. A small amount of morphine combined with a minimum dosis of scopolamine of which each alone is obviously without effect, produces a pronounced disturbance of the oxygen consumption. Traube ${ }^{1)}$ together with Onodera ascertained that when two narcotics or alkaloids were mixed and thereby a potentiated action took place, there was certainly a potentiated lowering of the surface tension and so the osmosis was lightened on the one side, but on the other side the inhibitory action of the mixture on oxidation was increased.

In all my experiments, evidence is put forward that the functional inactivity of the brain is connected with the disturbance of the energy exchange and the stronger the narcotic action, the greater is the latter which is yet not so great as Alexander and Cserna ${ }^{2)}$ announced. And however strong the narcotic effects on the brain may be, the gaseous exchange is not entirely checked so long as the blood flow continues.

When once the brain undergoes an action of a drug, the equilibriutn between the function, the gaseous exchange and the blood flow is disturbed for a long time.

The narcotics and hypnotics are characterized by the relatively prompt recovery of the change in brain function caused by them, but the reconvalescence of narcosis does not always seem parallel with the restoration of the cerebral blood flow, as shown in the experiments of ether, chloroform, chloral hydrate and alcohol, and often, as in the magnesium narcosis, antecedes by far that of the gaseous exchange and the blood flow.

As is well known, a special relation exists between the chemical structure of drugs and their actions ; for example, the ethyl group combined with tertiary or quartary C-atom as in veronal gives rise to a strong narcotic action. But in rabbits veronal is weak in hypnotic power and does not produce noticeable change in the gaseous exchange. The introduction of the phenyl group instead of one of the ethyl group of veronal, that is luminal, enhances the inhibitory effect on the cerebral function as well as on the gas metabolism in the brain. Thus it may be stated that the ethyl group has no special action on the brain function and its oxygen consumption.

1) Traube, Pflüger's Arch., 1913, 153, 309.

2) Alexander and Cserna, l. c. 
In the rabbit chloroform and chloral hydrate have a very strong depressive action not only on the brain, but also on the heart and the vasomotor centre, and differing from other drugs, the oxygen consumption in the brain is exceedingly disturbed in spite of the increased blood flow through the brain. Thus the introduction of halogen into the narcotics of the fatty bodies does not only increase the depressant effect on the brain as well as on the vasomotor centre and the heart, but also gives the mechanism of energy exchange a characteristic feature.

A few words about the relation of the amount of nacrotics coutained in the brain or blood to the rate of oxygen concumption of the brain. According to $\mathrm{Bachem} \mathrm{m}^{1}$, the minimum dose of narcotics contained in the brain which just causes the anaesthesia in the rabbit is : veronal $0.016 \%$, chloroform $0.018 \%$ and blood during deep sleep will contain 0.03-0.05\% veronal in the rabbit and 0.03-0.05\% chloral hydrate in the dog as a minimum.

Thus the effective concentration of veronal and chloroform in the brain is nearly the same, and also that of veronal and chloral hydrate in blood. But in my experiments it was shown that veronal does not remarkably influence the oxygen consumption in the brain while chloroform reduces it by $38.0 \%$, and also chloral hydrate by $34.6 \%$, a fact suggesting that the affinity of narcotics and hypnotics towards the brain and blood has no direct relation with the oxygen consumption in the brain.

It will be of interest, next to criticize the theory of narcosis observed from the sequences of my investigation. Meyer and Overton ${ }^{3)}$ announced a very close parallelism between narcotic efficiency and the partition coefficient: $\frac{\text { solubility in fat }(\mathrm{SF})}{\text { solubility in water }(\mathrm{SW})}$, but this fact does not explain the nature of narcosis, narcosis not being caused only by combining cell-lipoids with a fat-solvent. The finding of Meyer and Overton has a meaning in accelerating narcosis. Now looking for the relation between the disturbance of energy exchange which is connected with functional paralysis and the partition coefficient, we find no parallelism between them, as the following table shows:

1) Bachem, Arch. f. exp. Pathol. u. Pharmakol., 1910, 63, 228.

2) Meyer, Arch. f. exp. Pathol. u. Pharmakol, 1899, 42, 109.

3) Overton, Studien über d. Narkose, Jena 1901. 
TABLE XVIIT.

\begin{tabular}{|c|c|c|c|c|c|}
\hline \multirow[t]{2}{*}{ Drugs } & $\begin{array}{c}\text { Change in } \\
\mathrm{O}_{y} \text { consump. } \\
(\%)\end{array}$ & $\begin{array}{c}\text { Change in } \\
\text { blood flow } \\
(\%)\end{array}$ & \multirow[t]{2}{*}{$\begin{array}{c}\text { Partition } \\
\text { coefficient }\end{array}$} & \multirow{2}{*}{$\begin{array}{l}\text { Minimum } \\
\text { narcotic con- } \\
\text { centrat. for } \\
\text { tadpoles in } \\
\text { mol }\end{array}$} & \multirow{2}{*}{$\begin{array}{l}\text { Capillary ris- } \\
\text { ing of } 1 \text { mol } \\
\text { water solution } \\
\text { at } 15^{\circ} \text { (water } \\
=91.5 \text { mm.) }\end{array}$} \\
\hline & \multicolumn{2}{|c|}{ in the brain of rabbits } & & & \\
\hline Chloroform & $-38^{\circ} 0$ & + & $30-33$ & 0.0014 & - \\
\hline Ether & $-51 \cdot 6$ & - small & $4 \cdot 5$ & 0.034 & $67 \cdot 2$ \\
\hline Paraldehyd & $-42 \cdot 2$ & - large & $3 \cdot 0$ & 0.025 & $63 \cdot 9$ \\
\hline Chloral hydrate & $-34 \cdot 6$ & + & 0.22 & $0.025-0.02$ & - \\
\hline Ethyl urethane & $-40 \cdot 4$ & parallel & $0 \cdot 14$ & 0.04 & $79 \cdot 3$ \\
\hline \multirow[t]{2}{*}{ Ethyl alcohol } & somewhat &.$\quad$, & 0.083 & $0.27-0.31$ & $84 \cdot 0$ \\
\hline & \multicolumn{2}{|c|}{ (from my experiments) } & \multicolumn{2}{|c|}{$\begin{array}{l}\text { (from Winterstein's } \\
\text { "Die Narkose," Berl. } \\
\text { 1919. p. 208) }\end{array}$} & $\stackrel{(\text { from }}{\text { Traube }}$ \\
\hline
\end{tabular}

Remarks : + increased blood flow, parallel: the change in blood flow is parallel to that in $\mathrm{O}_{2}$ consumption, small: the decrease in blood flow is smaller than that in $\mathrm{O}_{2}$ consumption, large: the decrease in blood flow is larger than that in $\mathrm{O}_{2}$ consumption.

Contrary to Bürker"2) who described that narcotics dissolved in celllipoids and consumed oxygen as an oxidable substance and hereby produced asphyxia of cells, I found that alcohol, one of the strongest oxidable narcotics, provoked a very weak narcosis and a slight change in the oxygen consumption. Bernard's $s^{3)}$ statement that narcosis finds its origin in an incomplete blood supply to the brain was acknowledged by Frankfurther and Hirsch feld $d^{4)}$ who observed contraction of the brain volume during narcosis by chloroform or chloral, but was opposed by those who demonstrated an increase in the blood flow. Although in a great number of my experiments there was decrease in the blood flow, early in the narcotic stage of chloroform or chloral narcosis it was augmented, showing dilation of the cerebal vessels, and on the contrary in the reconvalescent stage or after awaking a remarkable reduction of the blood flow was ascertained. This fact denies any direct relation between the blood flow and the narcotic action. Nevertheless the increase in the blood flow has a great influence upon the oxygen consumption in the brain; when the blood flow is accelerated, the decrease

1) Traube, l.c.

2) Bürker, Münch. med. Wochenschr., 1910, 1443.

3) Bernard, Leçons sur les anesthésiques et sur l'asphyxie. Paris 1875. Cit in H. Winterste in, "Die Narkose," Berl. 1919, 128.

4) Frankfurther and Hirschfeld l.c. 
in the oxygen consumption is comparatively not great, though the narcotic effect is strong, and on the contrary decreased blood flow is followed by reduced gaseous exchange notwithstanding a slight anaesthesia.

Another theory of narcosis was brought foward by Traube ${ }^{1)}$. He proved a close relation of the narcotic efficiency to the surface tension of the solution of narcotics closer than to the solubility in fat, and concluded that narcotics such as bradyator, depressed oxidation independently of the presence of lipoids. My experiments resulted in a more or less slowing of oxidation in nearly every kind of narcotics and hypnotics, and the decrease in the oxygen consumption was slight in such as alcohol of which the surface tension is high, whereas it is marked in such as ether indicating low surface tension. However, $\mathrm{K} n$ affl and Lenz $z^{2}$ insisted that the relation of the narcotic power to the surface tension is less close than to the partition coefficient and Traube's surface tension theory is not in opposition, but rather supports the lipoid theory. Lilli $\mathrm{e}^{3)}$ has recently pointed out that process of excitation depends on increased permeability of plasma membrane, and all conditions which lessen the permeability result in depression; narcotics gather on lipoids of plasma membrane and diminish the permeability and consequently the excitability. And according to Winterstein ${ }^{4)}$, the change in this permeability is completely reversible.

The colloid-chemical interpretation has found another powerful support in the studies on the narcotic action of a substance which is not a fat-solvent like magnesium salts, while Stran sky $y^{5)}$ who confirmed that isotonic magnesium chloride solution acts as "entquellend" on the brain emulsion and calcium salts behaving antagonistic action against it, also act as "entquellend," thinks of the nature of narcosis as still unexplained.

W a rburg ${ }^{6)}$ ascertained that the change in the plasma membrane not only controls the excitability of the cells, but also has an important effect on their oxidative process and narcotics act as "Antikalysator." In my experiments the descent of the oxygen consumption was confirmed more or less not only with all kinds of lipoid-soluble narcotics, but also with alkaloids and other fat-insoluble narcotics like magnesium.

1) Traube, l. c.

2) Knaffl and Lenz, Arch. f. exp. Pathol. u. Pharmakol., 1919, 84, 66.

3) Lill ie, Amer. Journ. Physiol., 1909, 24, 14 . Ibid. 1912, 29, 372.

4) Winterstein, Bioch. Zeitschr., 1915, 75, 71.

5) Stransky, 1.c.

6) Warburg, l. c. 
Thus, it is a much vexed but very important question, whether the reduction in the gaseous matabolism of the brain which is to a more or less extent an invariable attendant of narcosis of every kind is the cause or sequence of the latter. As already mentioned in the introduction, Verworn ${ }^{1)}$ and Mansfel $d^{2)}$ believed in their oxygen deprivation theory of narcosis an oxygen deficiency in nerve cells as the ultimate cause of narcosis, which was opposed by Warburg and Winterstein ${ }^{3)}$, who observed that the oxygen consumption did not invariably decrease in narcosis, but may sometimes rather increase, and ascarides which, live anaerobically, are also subjects to narcosis. My investigation yielded certain evidences showing the divergence of the relation between the narcosis and the decline of oxygen exchange in the brain. For instance, in chloroform or ether narcosis the oxygen consumption remained depressed for a long time after revival of consciousness; on the combined injection of morphine and scopolamine the anaesthesia was of an insignificant degree, whilst the oxygen use markedly diminished; after the awakening of magnesium narcosis through administration of calcium, the gas exchange decreased further; on the other hand it was often with several kinds of narcotics noticed that in spite of deep anaesthesia there was only a slight decline of oxygen intake in the brain. Those facts will be enough to suggest that the oxygen deficiency is no causal factor for the developement of anaesthesia. In short, there is no close parallelism between the inhibition of the functional activity of the brain and the rate of depression of the oxidative process in it. The mechanism of the disturbed cerebral gas metabolism in narcosis has its own characteristic feature not only according to each drug which caused it but also in each period of narcosis.

\section{On the Brain Circulation during Narcosis.}

The relation between the oxygen consumption and blood flow in the brain during narcosis or hypnosis has already been discussed. Now the effect of narcotics and hypnotics on the brain circulation and its influence upon the activity of the brain will be reviewed and elucidated below. In general those druge whose narcotic or hypnotic power is very efficient, have also an eminent action on the brain circulation. Among them, narcotics of the alcohol group produce the most marked and the

1) Verworn, l. c.

2) Mansfeld, l.c.

3) Winterstein, Bioch. Zeitschr., 1914, 61, 81. Ibid. 1913, 51, $14 \%$. 
most interesting effects. The actions of ether, chloroform, chloral hydrate and ethyl alcohol are all the same; a preliminary increase in the blood flow in the early stage of narcosis provoked by them tends to decrease which decrease lasts for a long time, and the period in which the blood flow turns from plus to minus does not always coincide with the period of the change in the activity of the brain, especially of the loss of corneal reflex. The blood flow in chloroform narcosis is increased for longer than in the case of ether, often even at its narcotic stage, while that in ether narcosis tends sometimes to decrease already in the prenarcotic stage. With chloroform the reduction in the blood flow begins in the latter half of the narcotic stage, but it is of a high degree and lasts for a long time. With ether it recovers sooner than with chloroform ; in the reconvalescent stage of chloroform narcosis the blood flow tends to decrease still more notwithstanding the restoration of the blood pressure. The rate of the change in the cerebral blood flow is nearly equal in ether and in chloroform. With chloral hydrate its increase in the early stage of narcosis is very slight; it is rather distinctly accelerated in the period in which the corneal reflex is lost and the arterial pressure lowered, and diminishes when the corneal reflex reappears.

The augmentation of the blood flow in these drugs is independent of the change in the arterial blood pressure. The latter shows a marked fall in chloroform and more in chloral hydrate, probably due in part to the hulogen contained in them.

With ether, the blood flow decreases accompanied by no change in the blood pressure or exceeding the rate of the fall of blood pressure. The latter is also the case with chloroform. With chloral hydrate, the decline of the blood flow runs almost parallel to the fall of the blood pressure. Ethyl alcohol in the early stage of its action augments the blood flow without any change in the blood pressure in such a rate as in chloroform or ether, but later reduces it parallel with the blood pressure; nevertheless the decrease in both is very slight. The changes in the blood flow in the case of these drugs are caused chiefly by the dilation of the cerebral vessels followed by their contraction. Only in chloral hydrate and especially in alcohol the reduction of the blood flow, which is insignificant, may be attributed less to the contraction of the cerebral vessels than to the fall of the arterial blood pressure.

In the case of morphine, pantopon and veronal, there is no constant relation between the change in the blood flow and the arterial blood pressure. 
The decrease in the blood flow provoked by scopolamine is accompanied by the descent of the blood pressure, but there is some tendency to vasoconstriction. Combined narcosis of morphine and scopolamine shows no special effect on the cerebral vessels. With magnesium, urethane and luminal, the blood pressure and more distinctly the blood flow decreases, while with paraldehyd there is intensive diminution of the blood flow accompanied by no change in the blood pressure, suggesting the occurrence of a distinct contraction of the cerebral wessels. The decrease in the blood flow in the case of paraldehyd and magnesium surpasses that in the case of ether, chloroform and chloral hydrate. The decrease with trethane and luminal is also not less marked. In normal animals undergoing no action of drugs the blood flow follows the change in the arterial blood pressure, and suffers often from a marked decrease after repeated drawing of blood ; a variation of about 10 to $15 \%$ may be considered within the normal limit.

As to the vasomotor nerves for the brain, Riegel and Jolly ${ }^{1)}$, Gärtner and Wagner. Knoll ${ }^{3)}$, Roy and Sherrington ${ }^{4)}$ Hill and Macleodis), Bayliss and $\mathrm{Hill}^{6)}$ and others deny their existence. Roy and Sherrington concluded that there was no evidence of the existence of such nerves, and the chemical products of cerebral metabolism caused an active variation of the calibre of the cerebral vessels, whilst Bayliss and $\mathrm{Hill}^{6}$, opposing them, maintained that the cerebral vessels changed their calibre only passively.

However, Obersteiner ${ }^{7)}$ proved histologically the existence of the vasomotor nerves in the cerebral vessels and Nothnage $1^{8)}$, Krauspe $e^{(4)}$, Hürthl $\mathrm{e}^{10)}$ and $\mathrm{J}$ en se $\mathrm{n}^{11)}$ ascertained, basing their conclusions on their physiological researches, that vasomotor nerves for the brain were contained in the cervical sympathetic nerves of the same side. According

1) Riegel and Jolly, Virchow's Arch., 1871, 52, 280.

2) Gärtner and Wagner, l.c.

3) Kno 1l, Berichte d. Wiener Akadamie, III. part, 1878, 78, 233. Cited in Pick, Arch. f. exp. Pathol. u. Pharmakol., 1899, 42, 399.

4) Roy and sherrington, l. c.

5) Hill and Macleod. Journ. Physiol., 1900, 26, 394.

6) Bayliss and $\mathrm{Hill}$, l. c.

7) Obersteiner, Jahrb., f. Psych., 1897, 16, 215.

8) Nothnage l, Virchow's Arch., 1867, 40, 203.

9) Krauspe, Ibid. $1874,59,472$.

10) Hürthle, Pflüger's Archiv, $1889,44,561$.

11) Jensen, Ibid. 1904, 103, 196 
to Riedl and Reiner ${ }^{1)}$ and $\mathrm{Pick}^{2}$ the cerebral vessels undergo an active change independent of the general blood pressure, and Cavaz$\mathrm{zani}^{3)}$ found vasoconstictor and vasodilator fibres for the brain of the rabbit in the cervical sympathetic nerves. Wiechow $\mathrm{ski}^{4)}$ pointed out that vasomotor nerves in both sides of the hemispheres had no relation to each other, and finding that alcohol and strychnine had no effect on them, stated that not all of the blood vessel drugs produce the change in calibre of the cerebral vessels. Later $\mathrm{Weber} \mathrm{r}^{5)}$ reported as follows: in the cervical sympathetic nerves and the vagus were contained nerve fibres the stimulation of which dilates or contracts the cerebral vessels, but they had no relation to the vasomotor centre in the medulla oblongata, because although alcohol dilated both the cerebral and the abdominal vessels, its effect on the latter lasted longer than that on the former, probably due to the difference of point of attack in both cases. Weber $\mathbf{r}^{4}$ obtained on administration of caffeine a temporary dilation of the cerebral vessels followed by contraction lasting for a long time. Similar behavior was observed in my experiments on administration of chloroform, ether, chloral hydrate and ethyl alcohol. Weber ${ }^{5)}$ added that the change in the cerebral vessels of the hemisphere was equal on both sides, because of the connection of the vasomotor nerves of the large vessels of the cerebral basis on both sides.

In some of my experiments the variations of the cerebral circulation follow the changes in the general arterial pressure, but some narcotics and hypnotics change the blood flow through the brain independently of the blood pressure, not a few cases show markedly decreased or increased blood flow while the blood pressure remained unaffected or the blood flow changed in a direction opposite to that in the blood pressure. This fact leads us to accept presumably active dilation or contraction of the cerebral vessels.

Frankfurther and Hirschfeld $d^{(5)}$ concluded that in the brain, as in other organs, its activity accompanied the increase in the blood flow, its inactivity on the contrary the decrease and the alteration of the blood flow caused by drugs plays a rôle in the appearance of the effect

1) Riedl and Reiner, Pflüger's Arch., 1900, 79, 158.

2) Pick, l. c.

3) Cavazani, Arch. Italiennes de Biol., 1893, 19, 214.

4) Wiechowski,l.c.

5) Weber, Arch. f. (Anatom. u) Physiol., 1908, 457. Ibid. 1909, 348.

6) Frankfurther and Hirschfeld, l.c. 
of the drugs on the central nervous organs. Similar facts have been found also in some of my experiments ; the blood flow through the brain increased in the prenarcotic stage of narcosis and decreased in its narcotic stage as well as during the depression caused by many hypnotics. However in some others the parallelism between the action of drugs on the cerebral function and that on the brain circulation could not be demonstrated; for instance, during the depression due to chloroform and chloral hydrate the cerebral circulation was distinctly accelerated, also though to a small extent with morphine, pantopon and veronal, while it not infrequently decreased in the reconvalescent stage of narcosis or after awakening. Only in the case of long durating narcosis there was as a rule a reduction in the blood flow through the brain which lasted till after the revival of the activity of the brain.

Whether the central nervous system is glandular, muscular or other special tissue in the order of oxygen requirements, is determined by securing the gaseous exchange not only when the brain is at rest, but also when it is thrown into varying degrees of activity. While $\mathrm{Hill}$ and $\mathrm{Nabarr} \mathrm{o}^{1)}$ by experiment proved a quite low oxygen consumption in the brain, Alexander and Cserna described it as exceedingly vigorous. This problem will be treated in my next paper.

\section{Conclusions.}

1. A method is described of estimating the blood flow through the brain by measuring the mass movement of blood through the superficial temporal vein, the direct continuation of the transversal sinus, which is operated as the only vessel collecting the blood flow through the brain.

2. In the prenarcotic stage of ether narcosis both the cerebral blood flow and the oxygen consumption in the brain increase, in most cases parallel to each other.

In the narcotic stage there is a decrease in the oxygen consumption by $51.6 \%$ on an average, also a reduction of the blood flow; the rate of the former is greater than that of the latter.

The cerebral ressels dilate in the prenarcotic stage, but in the narcotic stage the blood flow decreases, the blood pressure remaining unchanged or descended.

In the reconvalescent stage of the narcosis the oxygen consumption

1) Hill and Nabarro, l. c.

2) Alexander and Cserna, l. c. 
revives hand in hand with the restoration of the activity of the brain, but not to the normal value, presumably owing in part to the incomplete revival of the blood flow.

3. In the prenarcotic stage of chloroform narcosis also both the blood flow and the oxygen consumption in the brain increase, but the latter in a smaller rate than the former. The excitement of the animal is in general of slighter degree and of shorter duration than that of ether narcosis.

In the narcotic stage the gas metabolism diminishes, the blood flow decreases or on the contrary increases. The depressant effect is so serious that in spite of often augmented blood flow the oxygen consumption decreases by $38 \%$ on an average. That this rate of decrease is a little inferior to that by ether is due to the fact that the inhibitory effect on oxygen consumption is partly compensated by the increase in the blood flow. The disturbance of gaseous exchange results from the direct action of chloroform on the brain, and not from a secondary one occurring from the change in the blood flow. In the reconvalescent stage of chloroform narcosis the oxygen consumption nearly revives, while the blood flow decreases fiurther. The evidence that the oxygen consumption approaches to the normal value in spite of the more diminished bloodflow suggessts that in the reconvalescent stage of chloroform narcosis the revival of the depressant effect on the activity and the oxygen consumption of the brain is comparatively prompt and complete. The cerebral vessels at first dilate, but at the later period of narcosis, where the blood pressure is lowered or suffers no change, there is a decrease in the blood How which is well marked and lasts for a considerable time.

One of the most remarkable differences between the actions of chloroform and ether is the fact that the blood flow in the reconvalescent stage of chloroform narcosis decreases further though the blood pressure is restored, while in the case of ether it tends to restore, the blool pressure remaining still lowered.

4. The morphine and pantopon, the efficacy of which as anaesthetics is very incomplete, act on the cerebral circulation insignificantly and not definitely. In rabbits the decrease in the oxygen consumption of the brain due to morphine is of very small extent, only $13.6 \%$ on an average. Pantopon causes a slightly greater decrease.

5. In the case of scopolamaine the blood flow through the brain decreases slightly, following the fall of the blood pressure ; the oxygen consumption in the brain remains unchanged. 
6. In the combined administration of morphine and scopolamine the change in the cerebral blood flow follows that in the blood pressure. The oxygen consumption decreases considerably, at a rate not inferior to that in the case of chloroform or ether, and far greater than the decrease in the blood flow. Scopolamine accelerates the inhibitory effect of morphine on cerebral oxidation, but does not modify that on the brain circulation.

The fact that a combination of half an amount of just effective dosage of morphine and a minimum dosis of scopolamine which alone is without effect, produces a pronounced disturbance in the oxygen consumption is another evidence that the combined use of certain pharmacological agents developes an effect several times greater than that caused by each drug.

7. The influence of magnesium narcosis on the oxygen consumption in the brain is not surpassed by that of ether or chloroform narcosis. The oxygen consumption tends to decrease nearly parallel to the decline of the blood flow, but sometimes diminishes without any change in the blood flow. Thereby the blood pressure is lowered or unchanged. Injection of calcium interrupts the magnesium narcosis promptly, but does not revive the gaseous exchange.

Injection of calcium into normal rabbits produces no change in the blood pressure. The blood flow through the brain remains unaffected, or sometimes declines slightly. The cerebral oxygen consumption tends to decrease.

8. In the case of chloral hydrate, the blood flow through the brain increases or is unchanged during the lost corneal reflex and the lowered blood pressure, while it decreases, when the corneal reflex reappears, in proportion to the lowering of the blood pressure. In spite of this increase in the blood flow, the oxygen consumption diminishes by $34.6 \%$ on an average; thus the disturbance of the gas metabolism in the brain caused by chloral hydrate depends on its direct effect on the brain, but not on the reduced blood flow.

9. In the case of paraldehyd the blood flow through the brain decreases distinctly without any change in the blood pressure. The rate of the decrease in the oxygen consumption is less than that in the blood flow, but greater than that in the oxygen consumption in the case of chloral hydrate. The effect of paraldehyd on oxygen consumption in the brain may in part secondarily result from the change in the blood flow through the brain. 
10. In the anaesthesia by urethane the blood pressure decreases slightly and the blood flow through the brain markedly. The decrease in the oxygen consumption (40.4\% on an average) is proportional to that in the blood flow.

11. Veronal causes no constant change in the blood flow through the brain and only a slight change in the oxygen consumption.

12. In the case of luminal the decrease in the blood flow through the brain is always accompanied by the fall of the blood pressure. The rate of decrease in the oxygen consumption is about the same as that in the case of urethane, is parallel to, or less than that in the blood flow.

13. Ethyl alcohol acts like ether, chloroform and chloral hydrate, first dilating, then contracting the cerebral vessels. But the constrictive power of alcohol is smaller than that of these drugs. The oxygen consumption in the brain is augmented during the increased blood flow; the smaller the dosage of alcohol the greater is the increase in the oxygen consumption. In a few minutes after the injection the oxygen consumption in the brain begins to decrease nearly parallel to the decline of the blood flow. With a large amount of alcohol the decrease in the oxygen consumption is somewhat greater than that of the blood flow.

14. On the whole during all cases of nacrosis and hypnosis in rabbits the gaseous exchange in the brain distinctly decreases; the cerebral blood flow too declines in nearly all cases, but the change in both does not always run in the same direction, and has some characteristic feature in each drugs and at each period of the action of the drugs.

When there is no central action, the gaseous exchange in the brain changes generally according to the blood flow. In the case of strong narcotic and hypnotic action, the oxygen consumption decreases independently of the change in the cerebral blood flow.

In slight narcosis and in many cases of hypnotics, the decrease in the oxygen consumption in the brain is parallel to or less than the decline of the blood flow.

15. In narcosis as well as hypnosis, there is not always close agreement between the change in the blood flow and that in the activity of the brain nor between the change in the brain activity and that in the cerebral gas metabolism.

16. Inactivity of the brain is not always accompanied by the decline of the blood flow through the brain, but when narcosis or hypnosis 
is continued for a long time there is always a decline of the blood flow to a more or less extent, which lasts even after the revival of the cerebral function.

17. There is no evidence showing that the disturbance of the oxygen intake in the brain is the causal factor of narcosis.

18. The cerebral vessels dilate or contract actively. 